\title{
A Method for Producing Fine-Grained Ice from Snow by Compaction
}

Deborah Diemand and Valery Klokov

August 2001 
Abstract: This report describes a preliminary study of the fabrication of building blocks by converting snow directly to ice without the very high energy cost of melting it first. This was accomplished by a hot sinter technique that produced a very fine-grained material that is considerably stronger than natural ice. The very high pressures applied to the snow appear not only to have reduced the grain size present in the raw material (natural snow), but to have completed the sintering process before the block was removed from its form, as there was no convincing increase in strength at any storage temperature over a period of 20 days, nor were there any striking crystallographic changes.

How to get copies of CRREL technical publications:

Department of Defense personnel and contractors may order reports through the Defense Technical Information Center:

DTIC-BR SUITE 0944

8725 JOHN J KINGMAN RD

FT BELVOIR VA 22060-6218

Telephone (800) 225-3842

E-mail help@dtic.mil msorders@dtic.mil

WWW http://www.dtic.mil/

All others may order reports through the National Technical Information Service:

NTIS

5285 PORT ROYAL RD

SPRINGFIELD VA 22161

Telephone (703) 487-4650

(703) 487-4639 (TDD for the hearing-impaired)

E-mail_orders@ntis.fedworld.gov

WWW http://www.ntis.gov/index.html

A complete list of all CRREL technical publications is available from USACRREL (CEERD-IM-HL)

72 LYME RD

HANOVER NH 03755-1290

Telephone (603) 646-4338

E-mail erhoff@crrel.usace.army.mil

For information on all aspects of the Cold Regions Research and Engineering Laboratory, visit our World Wide Web site:

http://www.crrel.usace.army.mil 


\section{Technical Report ERDC/CRREL TR-01-12}

\section{A Method for Producing Fine-Grained Ice from Snow by Compaction}

Deborah Diemand and Valery Klokov 


\section{PREFACE}

This is an interim report on current studies directed towards the development of methods to manufacture building blocks by compressing snow. It provides a record of information that has been gathered so far and gives direction for further efforts. The work was carried out by Deborah Diemand, Research Physical Scientist, Applied and Military Engineering Branch, Engineer Research and Development Center (ERDC), U.S. Army Cold Regions Research and Engineering Laboratory (CRREL), Hanover, New Hampshire, and by Dr. Valery Klokov, Consultant.

This research was supported by the U.S. Army Corps of Engineers through RDT\&E Project 4A762784AT42, Design, Construction and Operations Technology for Cold Regions, Work Package 157, Winter Operability, and Work Unit AT42-CS-W04, Low Temperature Performance Constraints. Additional funding was provided by DA Project 4A762784AT42, Cold Regions Engineering Technology, Work Package 147, Army Mobility in Cold Regions, and Work Unit AT42-CS-M03, Vehicle Mobility in Deep Snow.

The authors are grateful to Russ Alger, Ted Strieter, and their colleagues at the Keeweenaw Research Center, Houghton, Michigan, for their assistance and technical support.

This publication reflects the personal views of the authors and does not suggest or reflect the policy, practices, programs, or doctrine of the U.S. Army or Government of the United States. The contents of this report are not to be used for advertising or promotional

purposes. Citation of brand names does not constitute an official endorsement or approval of the use of such commercial products. 


\section{CONTENTS}

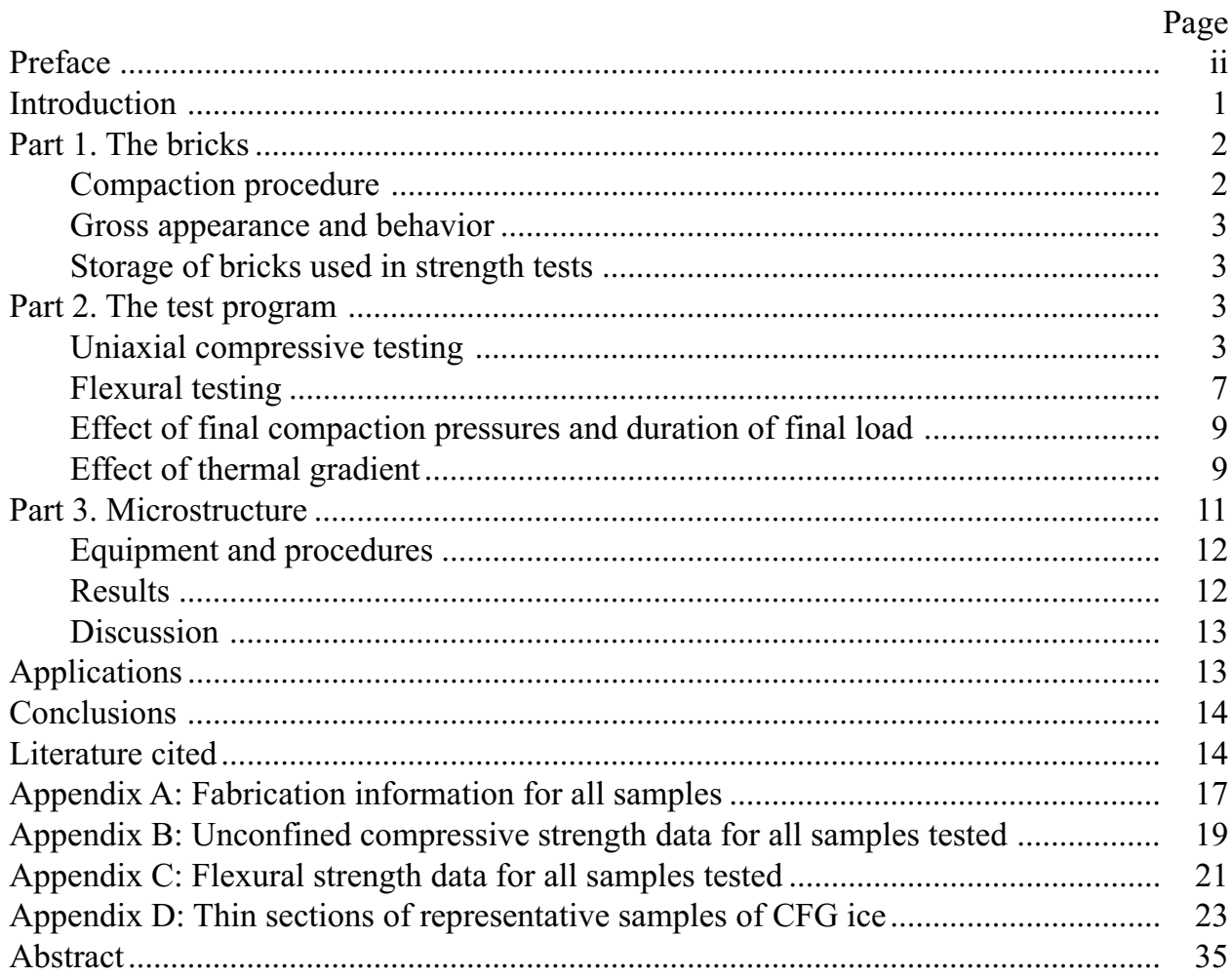

\section{ILLUSTRATIONS}

Figure

1. Steel form used to produce compacted snow/ice samples .................................

2. Cutting pattern used in preparing samples for use in uniaxial compressive strength testing and for crystallographic studies 
3. Platens used for compressive strength tests in this study

4. Instron Universal Testing Instrument used for compressive strength tests ........... 5

5. Uniaxial compressive strength of all samples, showing that there is no convincing evidence of the effect of storage time or temperature on the strength of the material

6. Relationship between grain size and unconfined compressive strength of ice at $-10^{\circ} \mathrm{C}$ and strain rate of $10^{-3} \mathrm{~s}^{-1}$

7. Mitering jig used for cutting disks for flexural strength testing

8. CRREL snow load frame used for flexural strength testing .............................. 7

9. Density in $\mathrm{kg} / \mathrm{m}^{3}$ of snow compacted at different pressures .............................. 8

10. Snow mound enclosing the stack of 12 sample bricks used to study the effect of a thermal gradient on $\mathrm{CFG}$ ice ....

11. Temperature profile showing the temperature variation over two weeks at six levels in the stack of sample bricks

12. Cut face of the stack of sample bricks at the end of the test.....

13. Horizontal section of the interface between the CFG ice of the bottom brick and the surrounding snow ice in which it was embedded

14. Typical sample of CFG ice showing equiaxed crystals and small, uniformly distributed bubbles

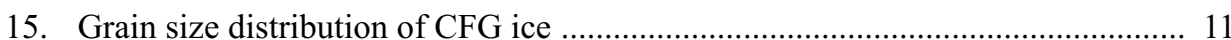

16. Microstructure of snow at various stages of compaction ................................. 12

\section{TABLES}

Table

1. Grain size distribution of natural snow used in this study beforeand after processing with a mixer

2. Unconfined compressive strength of CFG ice and natural ice used in this study

3. Adjusted flexural strength of CFG ice and natural ice used in this study 6

4. Comparison of the flexural strength of ice under different conditions

5. Compressive strength of CFG ice held in a thermal gradient .......................... 11 


\title{
A Method for Producing Fine-Grained Ice from Snow by Compaction
}

\author{
DEBORAH DIEMAND AND VALERY KLOKOV
}

\section{INTRODUCTION}

The use of snow as an engineering material in polar regions is not new. Aboriginal populations in northern areas have used snow for the construction of shelters such as Kinsey huts (by agitating and sintering the snow) and igloos (using blocks of unprocessed snow cut from the natural snow cover). These techniques use relatively low-density, and therefore low-strength, material unsuitable for load-bearing applications such as pavements or long-term usage such as semipermanent buildings.

Compacted snow roads and runways have been studied and used for many years in polar areas. Many techniques have been used with varying degrees of success, but the aim of all these techniques is to compact the snow and allow it to sinter to increase its strength. The density of the resultant material is generally in the range of 500 to $700 \mathrm{~kg} / \mathrm{m}^{3}$, and many months may be needed to reach maximum strength.

The most difficult aspect of the process is that, for maximum strength, the snow should be compacted at relatively warm temperatures and sintered at much lower temperatures. At low temperatures, compaction is difficult because of the lack of moisture in the snow, and the strengthening process is protracted. Techniques involving the addition of heat and/or water have been used with uneven results, and are often so fuel-intensive as to make them practically unfeasible for large-scale use.

While the behavior of compacted snow has been the focus of much research, little systematic consideration has been given to very high compression pressures such as those used in this study. We explored the feasibility of compacting snow at pressures up to
6.87 $\mathrm{MPa}$ (about $1000 \mathrm{psi}$ ) to produce ice of high strength that could be used to produce structures or pavements that could not be prepared using conventional techniques.

It is often the case that a compacted snow pavement made by conventional means is adequate for its task over most of its length, but becomes impassable over short transitional areas. Our proposal is to use highly compacted snow building blocks for these areas. Blocks with a density range on the order of 800 to $900 \mathrm{~kg} / \mathrm{m}^{3}$ should have the strength of ice, and would also minimize problems of vapor movement and infiltration of fluids, since these densities are very close to or beyond the density of pore close-off. Such blocks could also be used for making or crossing obstacles, as well as building semipermanent structures of many types, such as retaining walls and abutments, and snow shelters of greater size than are presently feasiblefor example, for equipment storage or instrumentation.

This report describes the hot pressing technique we used to produce very strong, tough material suitable for these purposes, and gives the results of our compressive and flexural strength tests. Hot pressing, in which particles of parent material near its melting point are compacted at high pressures, is often used in metal and ceramic manufacture because it reduces defect size and grain growth over the standard method of forming the material under pressure followed by heating to complete the sintering.

The crystallography of the material is of interest in its own right and is also discussed. The hot sintering method we used produced a material with considerably smaller grain size and greater uniformity than the parent material. 


\section{PART 1. THE BRICKS}

\section{Compaction procedure}

We used natural snow collected from an undisturbed drifted area to make the bricks. We gathered the snow in a large metal barrel and stirred it using a 3/4-in. electric drill equipped with a heavy wire whisk from a commercial food processor. Table 1 shows the grainsize distribution of this snow. The density of the snow after mixing ranged from 420 to $450 \mathrm{~kg} / \mathrm{m}^{3}$. The snow temperature at the time of compaction ranged from -5 to $-15^{\circ} \mathrm{C}$ and seemed to have little effect on the properties of the final product.

For this study the press available to us for producing sample bricks was a manually operated, 50-ton, upright, hydraulic press with a maximum useful load of about 15 tons. We used a Daytronic Model 441-50K load cell with a range of 0 to 50,000 pounds (about 25,000 $\mathrm{kg}$ ) and an electronic readout that enabled us to monitor the load as it was applied and hold it at the target load of 28,000 pounds for a final pressure of $1000 \mathrm{psi}$, or $6.87 \mathrm{MPa}$.

Because it was not feasible to produce large bricks using this press, we made small, round bricks using a short length of iron pipe with an inside diameter of $14.5 \mathrm{~cm}$ (6 in.) as the mold. This arrangement is shown in Figure 1. To prevent the compacted snow from sticking to the sides of the pipe and thereby damaging the sample, we used a plastic insert to line the mold, as shown. The mold had a series of holes set about 2.5 $\mathrm{cm}$ apart in two rows. These holes were concentrated in the lower half of the mold where the brick would be formed. The plastic liner was also perforated along a line about midway between the two lines in the mold. The purpose of these holes was to allow air to escape from the slowly compacting snow. While the holes in the plastic liner and those in the mold seldom lined up, the hissing of escaping air during compaction suggested that the arrangement was satisfactory. The steel disk placed on top of the sample before compaction fitted loosely and had five large (about $1 \mathrm{~cm}$ ) holes, which we felt were sufficient for air escape from the top. We put a sheet of plastic both under this disk and on the metal base plate to prevent the sample from sticking to the metal.

After compaction we used the press to push the brick out of the mold into a cylinder slightly wider than the mold. Each brick was stored in a plastic zipper bag

\begin{tabular}{|c|c|c|c|c|}
\hline \multirow{2}{*}{$\begin{array}{l}\text { Table } 1 . \mathbf{G} \\
\text { and after } \\
\text { ranged fro } \\
\text { cessed sn } \\
\text { Sieve no. }\end{array}$} & \multicolumn{2}{|c|}{ Undisturbed snow } & \multicolumn{2}{|c|}{ Mixed snow } \\
\hline & Weight (gram) & Percent & Weight (gram) & Percent \\
\hline & 9 & 6.1 & 2 & 0.9 \\
\hline No. 10 & 6 & 3.4 & 3 & 1.3 \\
\hline$(2 \mathrm{~mm})$ & 5 & 2.7 & 1 & 0.5 \\
\hline & & & 2 & 0.9 \\
\hline Average & 6.7 & 4.1 & 2 & 0.9 \\
\hline & 147 & 83.1 & 168 & 73.4 \\
\hline No. 20 & 124 & 71.3 & 161 & 70.9 \\
\hline$(0.84 \mathrm{~mm})$ & 144 & 78.7 & 152 & 68.5 \\
\hline & & & 135 & 63.1 \\
\hline Average & 138 & 77.7 & 154 & 69.0 \\
\hline & 13 & 7.3 & 25 & 10.9 \\
\hline No. 30 & 20 & 11.5 & 25 & 11.0 \\
\hline (0.59 mm) & 17 & 9.3 & 25 & 13.1 \\
\hline & & & 32 & 15.0 \\
\hline Average & 16.7 & 9.4 & 27 & 12.5 \\
\hline & 8 & 4.5 & 34 & 14.8 \\
\hline Remaining & 20 & 11.5 & 38 & 16.7 \\
\hline$(<0.59 \mathrm{~mm})$ & 17 & 9.3 & 40 & 18.0 \\
\hline & & & 45 & 21.0 \\
\hline Average & 15 & 8.4 & 39 & 17.6 \\
\hline
\end{tabular}




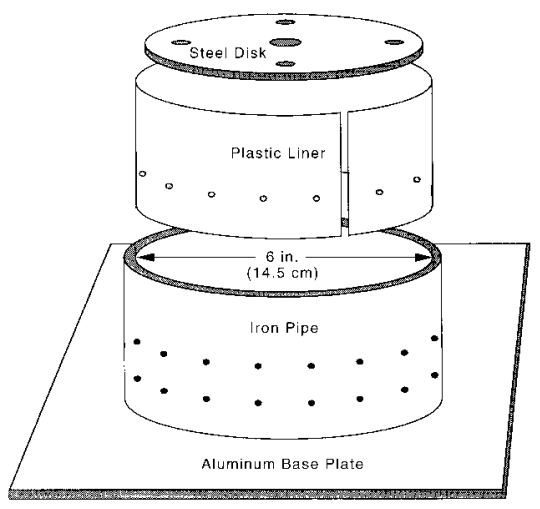

Figure 1. Steel form used to produce compacted snow/ice samples.

after its density had been determined and recorded. Most of the bricks in this study were made using 6.87 MPa pressure held for 30 seconds. The time to reach maximum pressure was about 60 seconds in all cases.

\section{Gross appearance and behavior}

In appearance the compacted material was uniformly white and completely opaque, the bubbles too small to be seen with the naked eye. During sample preparation either with bandsaw or handsaw there was little splintering. The only evidence of flaws was an occasional tendency to split horizontally into two or three slabs (normal to the stroke). This may have been an artifact of the removal from the mold. It usually happened immediately after fabrication, although we did lose one test brick that split as we were about to cut it at test time. Even immediately after the bricks had been removed from the mold, the material seemed strong and hard. It will be referred to in this report as "compacted fine-grained (CFG) ice."

\section{Storage of bricks used in strength tests}

Many researchers have demonstrated that the strength of compacted snow depends on its density and the duration and temperature of sintering (Butkovich 1962, Ramseier and Sander 1966, Abele et al. 1968). All of these studies dealt with lightly compacted snow with high porosity and considerable air circulation. In these circumstances the main processes driving the sintering of the material are evaporation, diffusion, and condensation. The CFG ice used in this study, however, had densities ranging from 800 to $890 \mathrm{~kg} / \mathrm{m}^{3}$. A density of $820 \mathrm{~kg} / \mathrm{m}^{3}$ is thought to mark the transition between compacted snow and ice, where pores in the material no longer communicate with one another (Abele and Gow 1976), so most samples were above the density of pore close-off and the few that fell beneath this would have had very limited evaporation and diffusion potential. We believed that the sintering process would be essentially complete at the time of fabrication; however, we produced three parallel series of bricks and stored them at three different temperatures $\left(-10^{\circ}\right.$, $-15^{\circ}$, and $\left.-25^{\circ} \mathrm{C}\right)$ for four time periods $(1,5,10$, and 20 days) to determine what effect, if any, time and temperature would have on CFG ice.

We produced a total of six bricks for each storage period and temperature. The $-15^{\circ}$ and $-25^{\circ} \mathrm{C}$ temperature series were kept in chest freezers, while the $-10^{\circ}$ series was kept in the coldroom and was therefore subject to a certain amount of temperature variation because of other activities in the coldroom, such as sample preparation, microscopic work, and so forth. Strength measurements were made after a total storage time of $1,5,10$, and 20 days. The pond and lake ice used as control was also stored in the coldroom until we were ready to cut it into test samples.

\section{PART 2. THE TEST PROGRAM}

We conducted four test series in this study as follows:

1) Unconfined compressive strength tests. This series of tests was done to evaluate the load-bearing potential of CFG ice. In addition, since this test has been performed on a wide variety of different ice types, it allowed us to compare the CFG ice with other, frequently studied, types of ice.

2) Flexural strength tests. The flexural strength of ice is usually studied to gain insights into the strength of a floating ice sheet as it applies to the load-bearing capacity of the sheet, forces on structures, ridge building processes, and so forth. We measured the flexural strength of CFG ice first to get an idea of its effectiveness as a pavement over a relatively soft base (snow, for example) and again to compare the CFG ice with other, frequently studied, types of ice.

3) Effect of final compaction pressure and duration of final load. This series was to determine whether pressures as high as $7 \mathrm{MPa}$ were required and what influence the duration of the final load had on the ice density.

4) Effect of storage in a thermal gradient. This test was to determine whether the CFG ice would weaken or recrystallize in a thermal gradient.

\section{Uniaxial compressive testing}

The measured strength of ice is affected by many factors, including grain size, type, and orientation; temperature; density; strain rate; inclusions; and salinity. All of these aspects have been studied for 
specific ice types and conditions, and general trends are well known. Our CFG ice was very fine-grained, equiaxed, isotropic material. The ice was free of particulates and because the snow from which it was made was collected from an undisturbed area, we assume that it had no substantial chemical contamination.

Data obtained for all samples tested are given in Appendix B.

\section{Samples and apparatus}

Because the minimum thickness of our bricks was $4.6 \mathrm{~cm}$, we used cubic samples $4.5 \mathrm{~cm}$ on a side as our sample configuration. Four such cubes were cut from each of two bricks for each set of conditions, resulting in eight samples for each sample series. The cutting pattern from each brick is shown in Figure 2.

We also collected bubbly ice from a local pond and clear ice from Lake Superior to test in parallel with our brick samples. The pond ice used was taken from a depth of about $15 \mathrm{~cm}$ beneath the ice surface as well as another sample from a depth of about $50 \mathrm{~cm}$. The
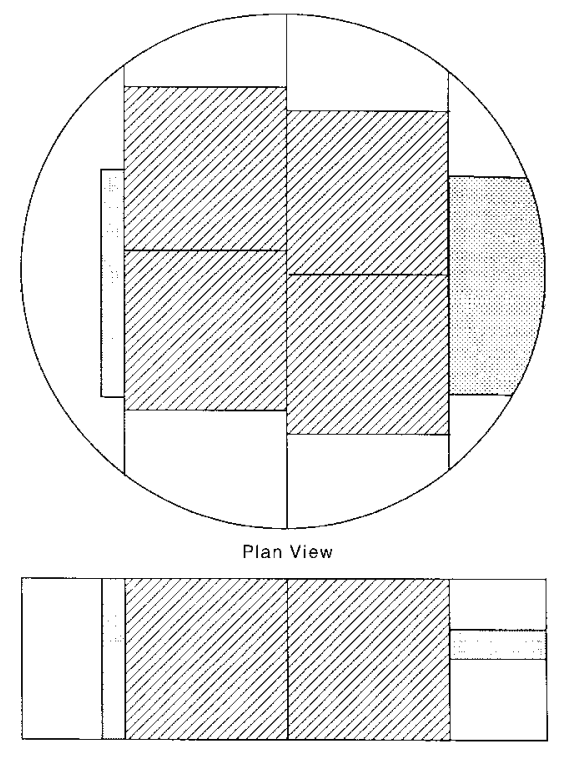

Side View

Figure 2. Cutting pattern used in preparing samples for use in uniaxial compressive strength testing (hatched areas) and for crystallographic studies (shaded areas).

$15-\mathrm{cm}$ ice was very bubbly and discolored snow ice. The 50-cm ice was less bubbly and discolored and had a density of $880 \mathrm{~kg} / \mathrm{m}^{3}$. The ice from Lake Superior was taken from a slab that had washed up onto the shore. It was very clear and clean and had a density of 920. All of these samples were stored in the coldroom
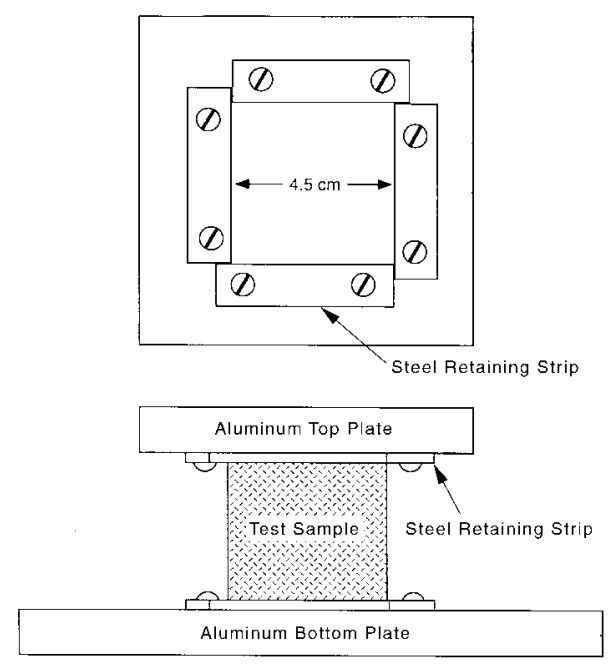

Figure 3. Platens used for compressive strength tests in this study.

at about $-10^{\circ} \mathrm{C}$ for a few days before they were cut and tested.

The samples were cut using a bandsaw and the cut faces were ground using sanding screen. The upper surface was marked with photocopier toner and the test samples were then returned to their storage temperature for a day before testing. The 1-day samples were prepared as soon as they were compacted and stored for one day in their test configuration. All samples were tested upside up.

A drawing of the platens we used is shown in Figure 3. The end plates were made of $1 / 2$-in.-thick aluminum, using the supplied factory finish. They were not polished or ground. Steel strips about $3 \mathrm{~mm}$ thick were attached to the plates as shown to ensure that the sample was centered under the head of the press and that the top plate did not move. The top plate was not attached to the head, and fitted loosely over the top of the sample, to minimize stress concentrations caused by any deviation from parallel of the top and bottom of the sample. Plastic sheeting was placed between the sample and both top and bottom platens.

We used an Instron Universal Testing Instrument (Instron Engineering Corporation) Model TTC overhead press with a rated load of about 10,000 pounds (about $5000 \mathrm{~kg}$ ) for the uniaxial unconfined compressive tests. The press speed measured without load was $0.08 \mathrm{~cm} / \mathrm{sec}$. We used a Sensotec Model 41/ 572-05 load cell with a range of 0-5000 pounds (about $2500 \mathrm{~kg})$. The linear motion transducer was a Lin-RTron Model LRT-S-050B with a range of 0-2 in. (0-5 $\mathrm{cm})$ and resolution of $100 \mu$. The load cell and the motion transducer readings were recorded in computer files, giving us time (in increments of $0.43 \mathrm{~s}$ ), load (in pounds) and displacement (in inches). These data were 


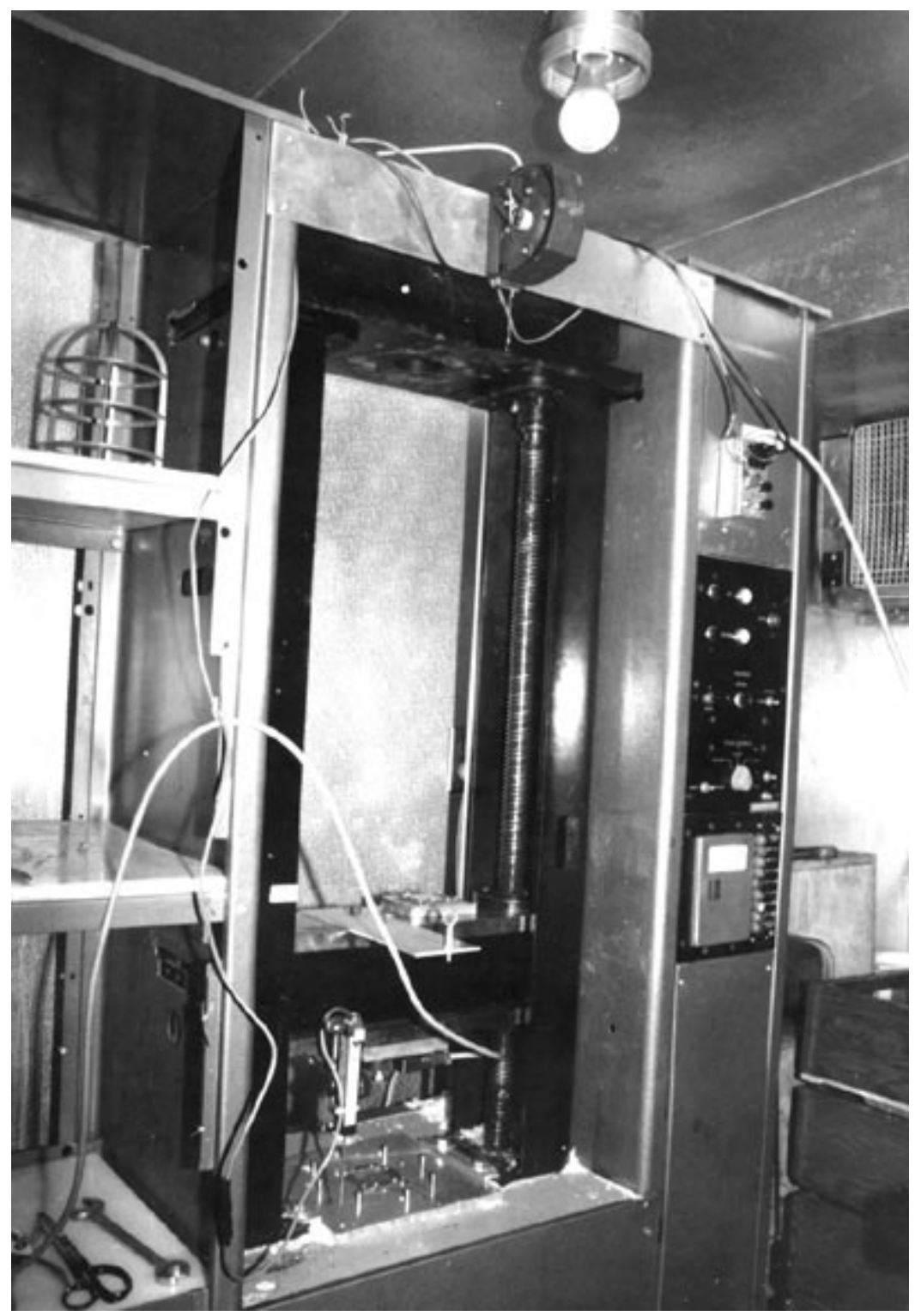

Figure 4. Instron Universal Testing Instrument used for compressive strength tests. The bottom platen is shown in place while the top platen is lying on top of the press head.

later converted to SI units. Figure 4 shows the press, load cell, motion transducer, and lower platen in place. The upper platen is lying loosely on top of the press head.

\section{Results}

Maximum compressive strength was calculated using the formula

$$
\sigma_{\mathrm{c}}=\frac{P_{\max }}{A}
$$

where $\sigma_{\mathrm{c}}=$ uniaxial compressive strength in $\mathrm{kg} /$ $\mathrm{cm}^{2}$, later converted to $\mathrm{MPa}$

$$
\begin{aligned}
P_{\max }= & \text { maximum measured force in } \mathrm{kg} \\
A= & \text { initial surface area of the sample in } \\
& \mathrm{cm}^{2} .
\end{aligned}
$$

The average strengths of our test series and of the natural ice we examined are given in Table 2. At the strain rate we used (about $1.6 \times 10^{-2} \mathrm{sec}^{-1}$ ), the natural ice was clearly in the brittle range while the CFG ice was in the region of flow with cracking. Therefore, the maximum stress measured for the natural ice was probably not the maximum possible, while that for the CFG ice very likely was. However, Hawkes and Mellor (1972), using ice similar to ours, found that the 


\begin{tabular}{|c|c|c|c|}
\hline \multirow[b]{2}{*}{ Storage time } & \multicolumn{3}{|c|}{ Storage temperature $\left({ }^{\circ} \mathrm{C}\right)$} \\
\hline & -10 & -15 & -25 \\
\hline 1 day & $9.12 \pm 2.16$ & $10.50 \pm 1.86$ & $11.58 \pm 2.06$ \\
\hline 5 days & $9.52 \pm 2.06$ & $10.01 \pm 2.65$ & $12.36 \pm 0.78$ \\
\hline 10 days & $9.22 \pm 2.65$ & $11.67 \pm 0.69$ & $10.99 \pm 2.35$ \\
\hline 20 days & $9.61 \pm 2.55$ & $10.99 \pm 0.98$ & $11.87 \pm 1.77$ \\
\hline Lake ice & $1.67 \pm 0.39$ & & \\
\hline Pond ice & $3.34 \pm 1.18$ & & \\
\hline
\end{tabular}

maximum axial stress increases with strain rate up to a rate of about $10^{-3} \mathrm{sec}^{-1}$. At rates greater than this the peak stress tends to remain constant. We therefore believe that the values we obtained for uniaxial strength are comparable.

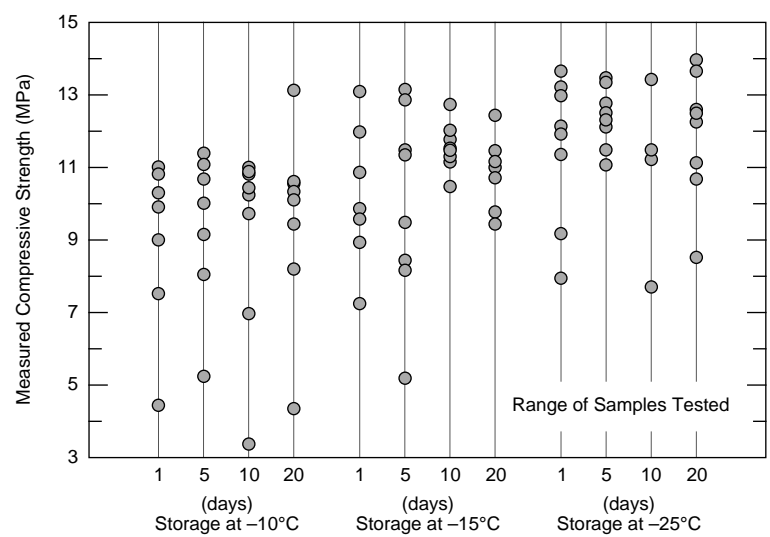

Figure 5. Uniaxial compressive strength of all samples, showing that there is no convincing evidence of the effect of storage time or temperature on the strength of the material.

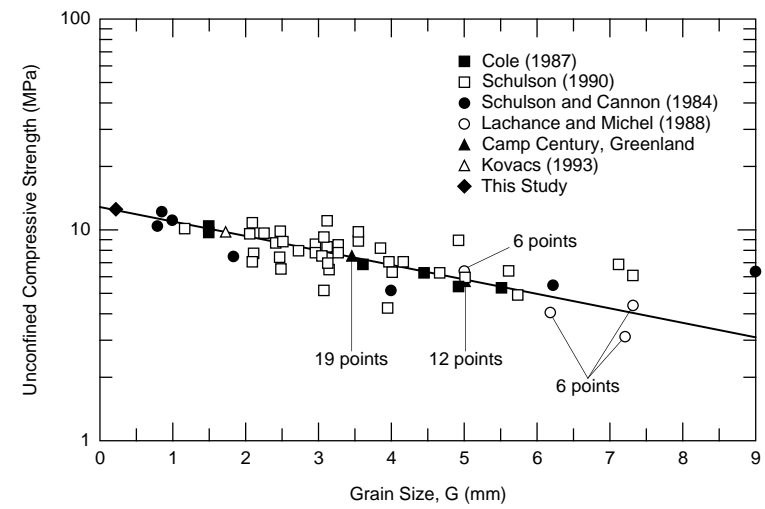

Figure 6. Relationship between grain size and unconfined compressive strength of ice at $-10^{\circ} \mathrm{C}$ and strain rate of $10^{-3} \mathrm{~s}^{-1}$. (After Kovacs 1993.)

\section{Discussion}

The greater part of the uniaxial unconfined compressive strength data reported in the literature was obtained using cylindrical samples. Because of the size of our compacted-snow bricks we chose to prepare cubical samples for this test series. Kuehn et al. (1992), using cubes of fine-grained ice (grain sizes about 1 $\mathrm{mm}$ ) ranging in size from 1 to $15 \mathrm{~cm}$ on a side, found that the ductile compressive failure strength is independent of the sample size, at least in the range they used. The strengths they measured were in good agreement with those of a previous series of tests using similar material in the form of right cylinders. At $-10^{\circ} \mathrm{C}$ and a strain rate slightly less than ours, they measured strengths of about 5.4 to $5.9 \mathrm{MPa}$ using cubes $4 \mathrm{~cm}$ on a side. We therefore believe that our data can be compared directly with those of other researchers who used similar test conditions; neither the size nor the shape of our samples had a significant influence on their measured strength.

It is clear from Table 2 that the uniaxial compressive strength of CFG ice is substantially stronger than that of the natural ice tested. Its strength was not appreciably affected by either its density or the length of time elapsed between fabrication and testing.

Figure 5 shows the measured compressive strength

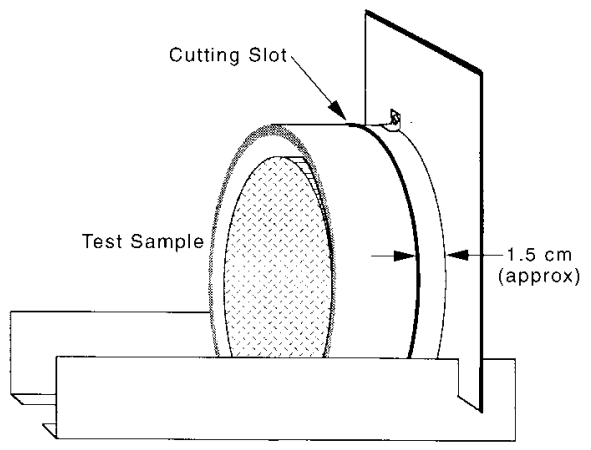

Figure 7. Mitering jig used for cutting disks for flexural strength testing. 


\begin{tabular}{|c|c|c|c|}
\hline \multirow[b]{2}{*}{ Test series } & \multicolumn{3}{|c|}{ Storage temperature $\left({ }^{\circ} \mathrm{C}\right)$} \\
\hline & -10 & -15 & -25 \\
\hline 1 day & $2.71 \pm 0.50$ & $2.65 \pm 0.26$ & $2.59 \pm 037$ \\
\hline 5 days & $3.04 \pm 0.36$ & $2.59 \pm 1.23$ & $3.11 \pm 0.53$ \\
\hline 10 days & $2.61 \pm 0.36$ & $2.70 \pm 0.28$ & - \\
\hline 20 days & $2.86 \pm 0.28$ & $3.17 \pm 0.34$ & $2.71 \pm 0.45$ \\
\hline Pond ice & $2.04 \pm 0.60$ & & \\
\hline Lake ice & $1.34 \pm 0.23$ & & \\
\hline
\end{tabular}

for all CFG ice samples against their temperature and duration conditions. There is no convincing evidence of time or temperature dependence over the range we used. This confirms our expectation that sintering was complete at the time of compaction.

Schulson and Cannon (1984) ran a series of uniaxial compressive tests on polycrystalline ice with grain sizes ranging from 1 to $10 \mathrm{~mm}$. They found a clear trend of increasing peak stress with decreasing grain size. In tests with high strain rates $\left(10^{-3} / \mathrm{sec}\right)$ this trend was especially pronounced. They also found a much higher peak stress with decreased grain size. In this case the

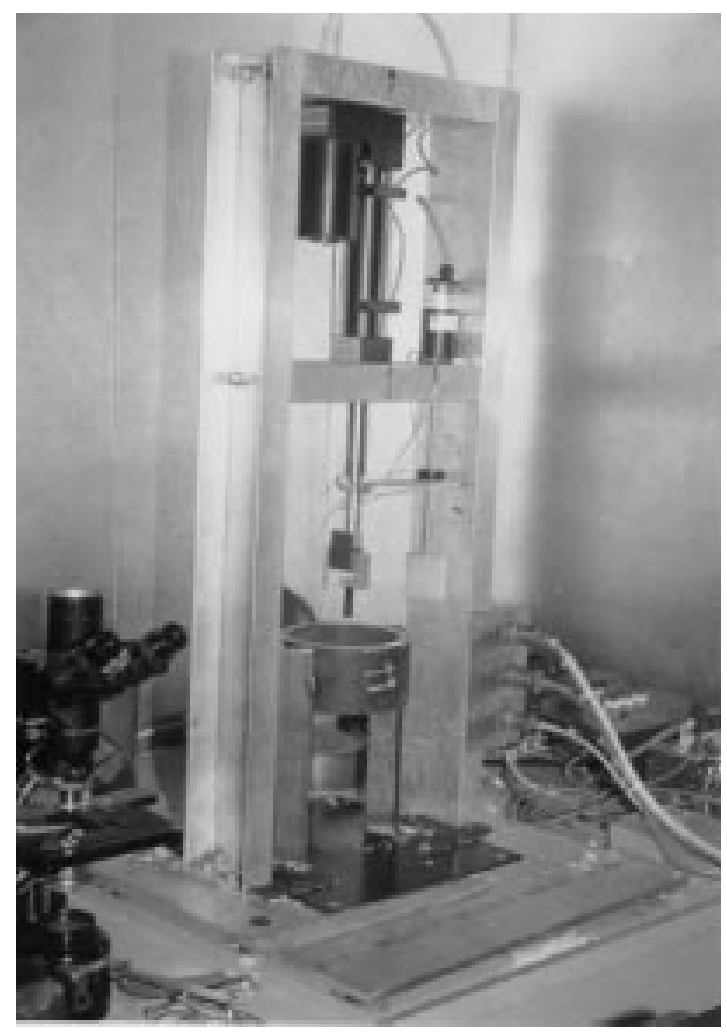

Figure 8. CRREL snow load frame used for flexural strength testing. The sample disk was placed across the metal cylinder centered beneath the indenter. trend was more pronounced at the lower strain rates $\left(10^{-6 / \mathrm{sec}}\right)$. Figure 6 shows the relationship between the unconfined compressive strength of ice and its grain size taken from a number of studies. The data from our brick material fall in the predicted area of the plot, although data from the pond and lake ice appear weaker than expected.

\section{Flexural testing}

Because the bricks we made were not large enough to conduct standard bending tests using beams, we used round plates (disks), a technique that is less well known, but for which data for comparison do exist in the literature. Lavrov (1969) describes a study in which both beam bending and round plate tests were done for ice collected during an Arctic cruise. The beambending strength was about $65 \%$ of that measured using round plates. That is,

$$
\frac{\sigma_{\mathrm{f}}^{b}}{\sigma_{\mathrm{f}}^{d}}=0.65
$$

where

$$
\sigma_{\mathrm{f}}^{d}=\text { beam-bending flexural strength }
$$$$
\sigma_{\mathrm{f}}^{b}=\text { disk-bending flexural strength. }
$$

A later study in the laboratory using laboratoryprepared and natural freshwater ice yielded the same relationship.

Data obtained for all samples tested are given in Appendix C.

\section{Samples and apparatus}

Flexural tests were made using disks cut from CFG ice cylinders produced by compaction. We used a handsaw and mitering jig, shown in Figure 7, to make disks about $1.5 \mathrm{~cm}$ thick for the flexural strength tests. We then planed the cut surfaces using sanding screen, and returned the disks to their assigned storage temperatures for a day along with the compressive test samples. Two samples were obtained from each brick. We obtained eight samples for each test series.

Sample disks were also made from the natural ice 
by cutting a cylinder out of the ice using a bandsaw and further cutting it into sample disks as described above. These were stored in the coldroom at about $-10^{\circ} \mathrm{C}$ for a day before testing.

We used the CRREL snow load frame for the flexural strength tests. This was equipped with an Interface, Inc., 250-pound load cell and Schaevitz MagneRule displacement transducer. The cylindrical indenter, attached to the load cell, was $1 \mathrm{~cm}$ in diameter with a flat tip. It was centered over a short section of iron pipe with an outside diameter of 6 in. $(15 \mathrm{~cm})$ and a 0.5 -in. $(1.25-\mathrm{cm})$ wall thickness, so that the brick samples fit across the opening without overhang. The press speed, without load, was $0.06 \mathrm{~cm} / \mathrm{sec}$. The apparatus is shown in Figure 8.

The flexural strength of the plates was calculated using the method described by Yakovlev (1971) and Lavrov (1969). The equation yields the maximum normal stress in a freely supported plate of constant thickness with a centrally located circular load:

$$
\sigma_{\mathrm{f}}=-\frac{3 P}{2 \pi m h^{2}}\left[m+(m+1) \ln \frac{r}{r_{0}}-(m-1) \frac{r_{0}^{2}}{4 r^{2}}\right]
$$

where $\quad \sigma_{\mathrm{f}}=$ flexural strength $\left(\mathrm{kg} / \mathrm{cm}^{2}\right)$, later converted to MPa

$P=$ maximum load $(\mathrm{kg})$

$m=$ inverse of Poisson's ratio

$h=$ plate thickness $(\mathrm{cm})$

$r=$ the inside radius of the supporting ring (cm)

$r_{0}=$ the radius $(\mathrm{cm})$ of the load (indenter).

Assuming a Poisson's ratio of $0.33, m$ becomes 3 .

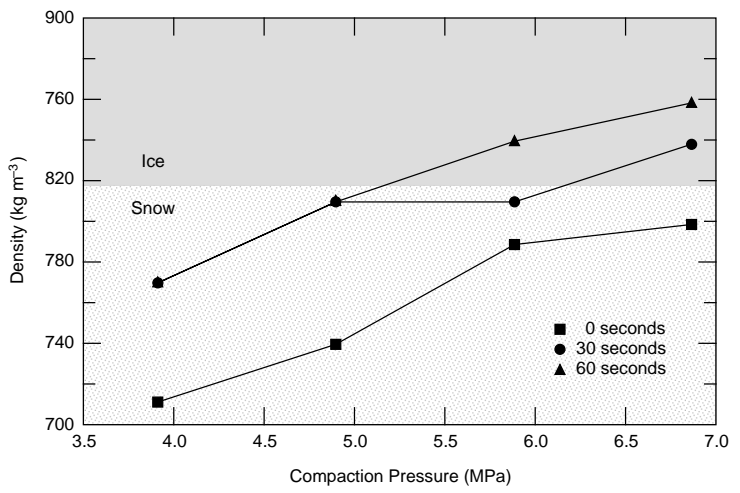

Figure 9. Density in $\mathrm{kg} / \mathrm{m}^{3}$ of snow compacted at different pressures. The different data series represent samples that were held at the final pressure for $\mathbf{0}, 30$, and 60 seconds.

Our supporting ring had an inside diameter of 12.65 $\mathrm{cm}$, giving $r=6.33$, and our indenter was a $1-\mathrm{cm}$ cylinder, giving $r_{0}=0.5$. Substituting these values, eq 3 becomes

$$
\sigma_{\mathrm{f}}=-\frac{2.09 P}{h^{2}} .
$$

\section{Results}

Table 3 gives the average flexural strength for each of the sample series. The strength was calculated using eq 4 , and this value was then multipied by 0.65 , the empirical coefficient determined by Lavrov to normalize the round plate tests with respect to beam bending tests. The strength values have been converted to $\mathrm{MPa}$.

Table 4 gives the flexural strength determined for various types of ice using beam bending and round plate methods. The round plate data have been normalized as above. The strengths calculated for the three series

Table 4. Comparison of the flexural strength of ice under different conditions. Test conditions and ice

\begin{tabular}{|c|c|c|c|c|c|}
\hline \multirow[b]{2}{*}{ Type of ice } & \multicolumn{2}{|c|}{ Beams } & \multirow[b]{2}{*}{$\begin{array}{c}\text { Test } \\
\text { temperature } \\
\left({ }^{\circ} \mathrm{C}\right)\end{array}$} & \multicolumn{2}{|c|}{ Disks } \\
\hline & $\begin{array}{c}\text { Test } \\
\text { temperature } \\
\left({ }^{\circ} \mathrm{C}\right)\end{array}$ & $\begin{array}{l}\text { Measured } \\
\text { flexural } \\
\text { strength } \\
(\mathrm{MPa})\end{array}$ & & $\begin{array}{c}\text { Measured } \\
\text { flexural } \\
\text { strength } \\
(\mathrm{MPa})\end{array}$ & $\begin{array}{c}\text { Adjusted } \\
\text { flexural } \\
\text { strength } \\
\text { (MPa) }\end{array}$ \\
\hline Sea ice (3 \%) (Lavrov 1969) & 1 & 0.75537 & 1 & 1.10853 & 0.721035 \\
\hline Sea ice $(0.5 \%)$ (Lavrov 1969) & 2.5 & 0.981 & 2.5 & 1.55979 & 1.014354 \\
\hline Artificial ice (Lavrov 1969) & -5 & $1.37-2.74$ & -4 & 2.3544 & 1.4715 \\
\hline Lake ice (S2) (Lavrov 1969) & -0.5 & $0.88-2.26$ & & & \\
\hline Lake ice (S2) (this study) & & & -10 & 2.0601 & 1.3734 \\
\hline Lake ice (Gow 1977) & 0 & $0.23-1.52$ & & & \\
\hline Freshwater (Schwarz and Weeks 1977) & & 1.03 & & & \\
\hline Snow ice (T1) (Stearns 1964) & -15 & 2.3544 & & & \\
\hline $\begin{array}{l}\text { Snow ice (T1) (this study) } \\
\text { Unknown (Gold 1977) }\end{array}$ & & & -10 & $\begin{array}{c}3.1392 \\
3.53-4.51\end{array}$ & $\begin{array}{c}2.0601 \\
2.26-2.94\end{array}$ \\
\hline CFG ice (this study) & & & -10 & $4.02-4.91$ & $2.55-3.14$ \\
\hline
\end{tabular}
type are given, where known. 


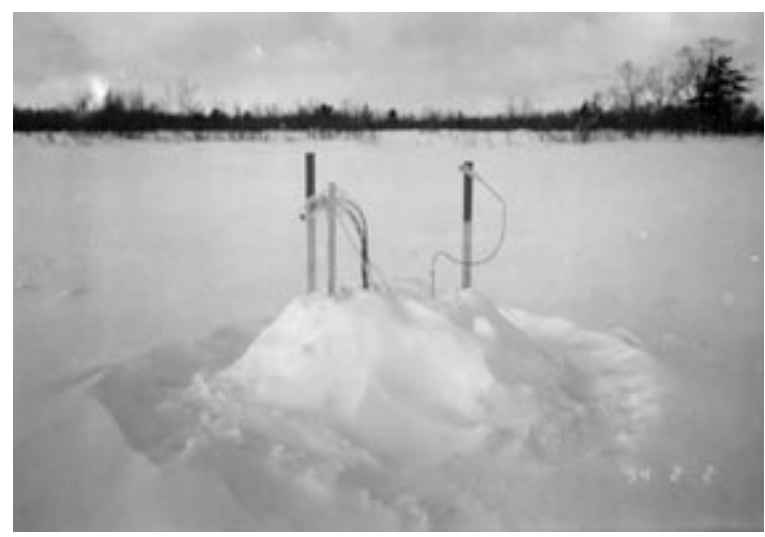

Figure 10. Snow mound enclosing the stack of 12 sample bricks used to study the effect of a thermal gradient on CFG ice. The cluster of wires on the left lead to the 12 thermocouples embedded in the stack. The single lead on the right leads to a thermistor probe installed about $10 \mathrm{~cm}$ from the stack. Plastic bags cover the connectors for all of these leads.

of tests in which Lavrov used both beams and plates show very good agreement between the adjusted plate data and the beam data.

The data we obtained using S2 ice collected from Lake Superior show good agreement with other determinations of this ice type, as did the snow ice (T1) results. The flexural strength measured for $\mathrm{CFG}$ ice was considerably greater than that for both the natural ice measured in this study as well as for all the other ice types except the series mentioned by Gold (1977). Since no details are available regarding the ice type or test temperature, we have no explanation for his observations.

\section{Effect of final compaction pressures and duration of final load}

To establish whether a compaction pressure as great as $6.87 \mathrm{MPa}$ was necessary to produce CFG ice, and how long the pressure should be held, we made a

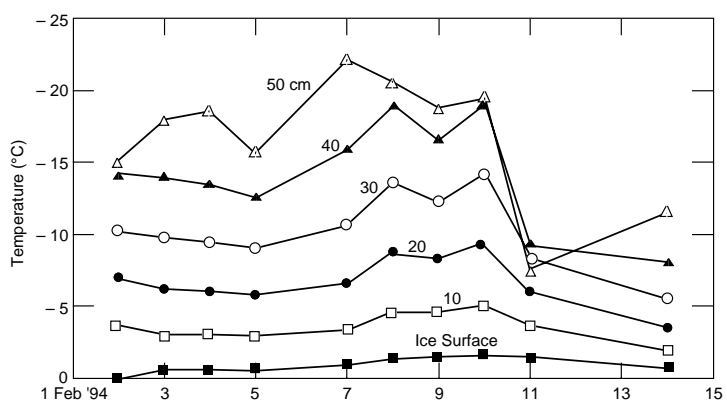

Figure 11. Temperature profile showing the temperature variation over two weeks at six levels in the stack of sample bricks. series of bricks using final pressures ranging from 3.92 to $6.87 \mathrm{MPa}$, and held the target pressure 0,30 , or 60 seconds. The load cell was placed between the hydraulic head and the sample to measure the load as it was applied, and to maintain the target pressure. The results of this trial series are shown in Figure 9. There is a clear trend toward greater density with greater pressure and greater time held. The density region above $820 \mathrm{~kg} / \mathrm{m}^{3}$, at which compacted snow is said to become ice, is shaded in Figure 9.

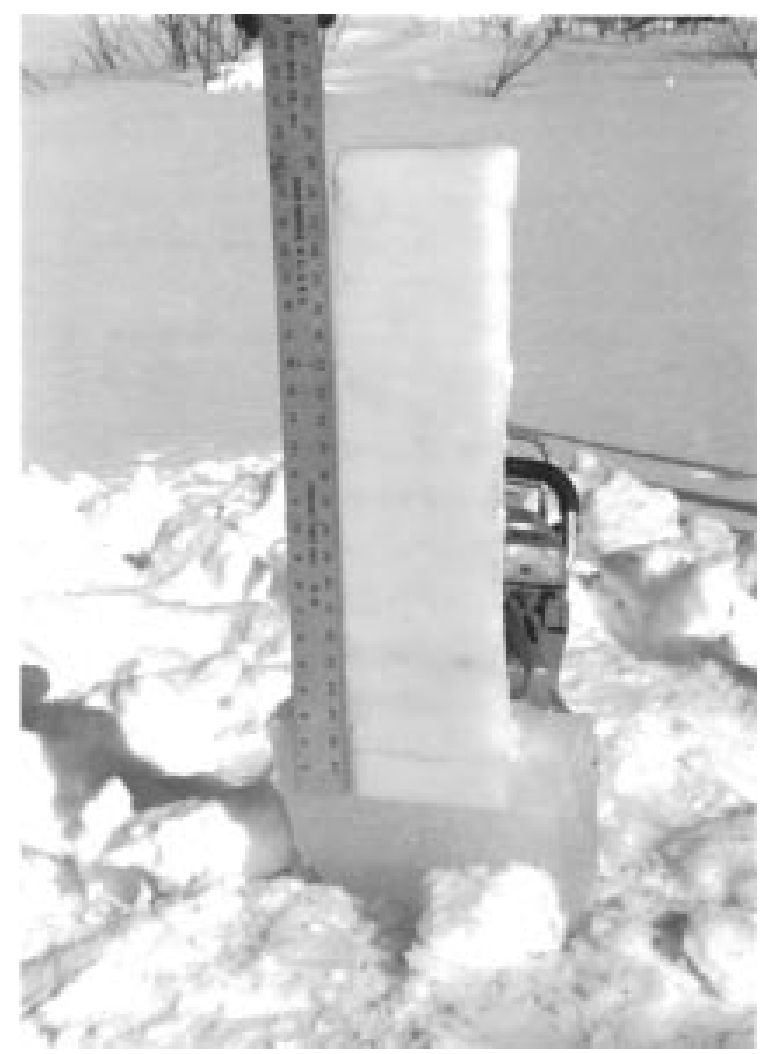

Figure 12. Cut face of the stack of sample bricks at the end of the test. The bottommost brick is embedded in snow ice because of flooding of the ice early in the test period. The measuring stick is marked in inches.

\section{Effect of thermal gradient}

Many potentially valuable applications for these building blocks involve using the material in a thermal gradient. Pavements over wet areas and walls of equipment shelters are two examples. Since compacted snow used in such conditions would quickly lose its strength and integrity through recrystallization, we tested the response of CFG ice to these conditions.

Twelve bricks were placed in a stack on the ice cover of a pond. The snow cover was cleared off so that the bottommost brick was in contact with the ice. A thermocouple was placed beneath the center of the 


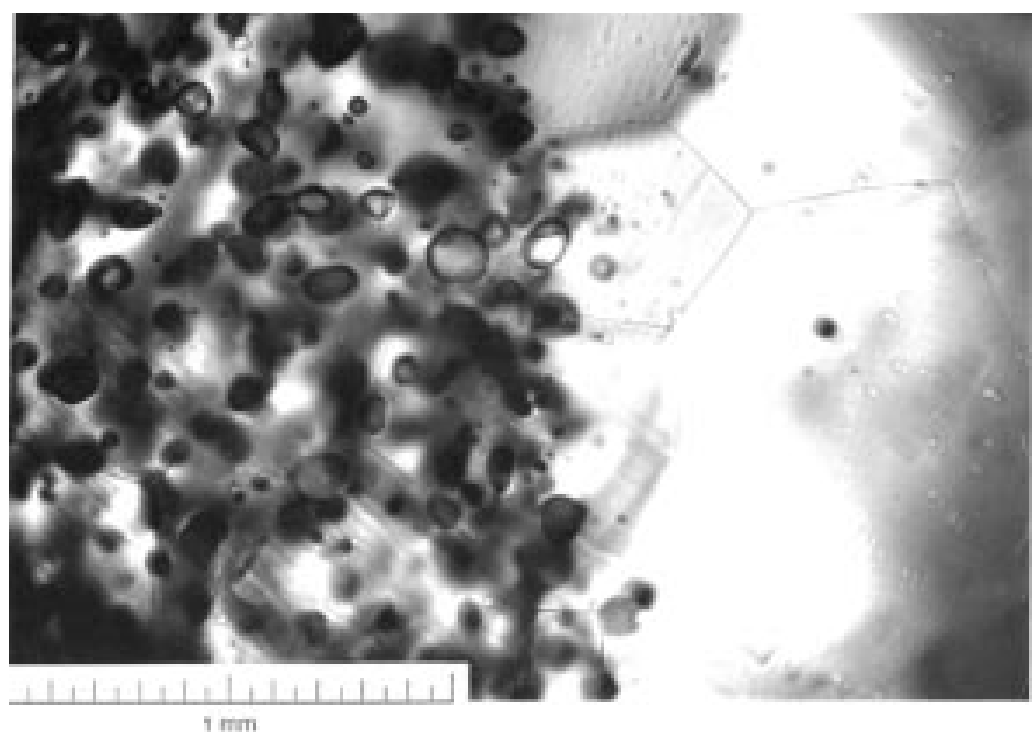

Figure 13. Horizontal section of the interface between the CFG ice (at left) of the bottom brick and the surrounding snow ice in which it was embedded. Some recrystallization has taken place.

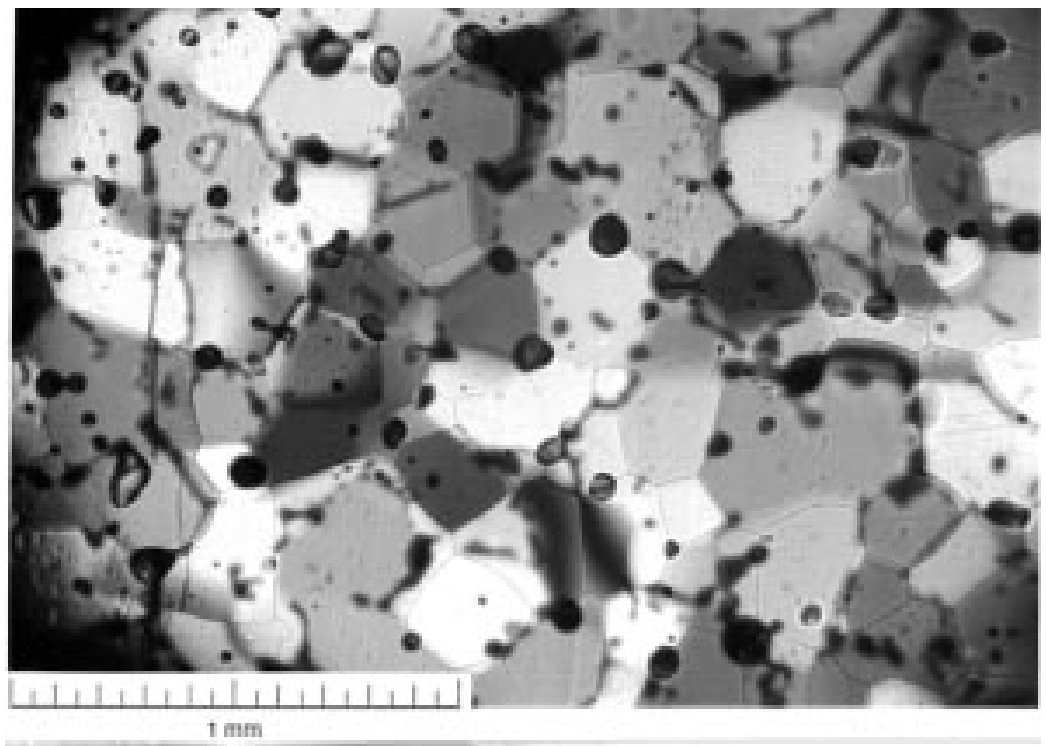

Figure 14. Typical sample of CFG ice showing equiaxed crystals and small, uniformly distributed bubbles.

brick. Another thermocouple was centered on top of the brick and another brick placed on top of this. Each successive brick was installed with a thermocouple in this manner. We then buried the stack with snow to minimize lateral thermal disturbance. Figure 10 shows the completed mound with the umbilicus of thermocouple leads and an embedded thermistor probe installed to confirm our readings. Because the readings taken from the thermocouples were up to $6^{\circ} \mathrm{C}$ higher than those taken from the thermistor string, including readings as high as $+2.6^{\circ}$ at the ice surface, we used the thermistor readings to determine the temperature profile of the mound. Figure 11 shows a plot of these temperature readings taken during the final two weeks of the test period.

Heavy snows resulted in about $5 \mathrm{~cm}$ of water flooding the ice. Figure 12 shows the stack of bricks after it had been removed from the ice. The stack has been sliced vertically using a chain saw. The bottom brick is embedded in newly formed snow ice because of the flooding. Figure 13 shows a horizontal section taken from the interface between the snow ice and the $\mathrm{CFG}$ ice. There is clear evidence of some 


$\begin{aligned} & \text { Table 5. Compressive strength of CFG ice held in a thermal gradient. The distances given are } \\
& \text { measured from the ice surface to the bottom of the brick. }\end{aligned}$
\begin{tabular}{cccc}
$\begin{array}{c}\text { Distance from ice } \\
\text { surface at the start }\end{array}$ & $\begin{array}{c}\text { Distance from ice } \\
\text { surface at the end } \\
(\mathrm{cm})\end{array}$ & $\begin{array}{c}\text { Average } \\
\text { temperature of } \\
\text { the layer }\left({ }^{\circ} \mathrm{C}\right)\end{array}$ & $\begin{array}{c}\text { Uniaxial } \\
\text { compressive strength } \\
(\mathrm{MPa})\end{array}$ \\
\hline 0 & -5 & -0.9 & 2.65 \\
5 & 0 & -0.9 & 7.26 \\
10 & 5 & -3.5 & 4.71 \\
15 & 10 & -3.5 & 4.22 \\
20 & 15 & -6.6 & 4.61 \\
25 & 20 & -6.6 & 4.71 \\
30 & 25 & -10.2 & 4.51 \\
\hline
\end{tabular}

recrystallization, but crystal sizes remain relatively small (less than $1 \mathrm{~mm}$ ) even at the warm temperatures at this level.

The compressive strength was measured for the seven lowest bricks, and the values are given in Table 5 along with the approximate average temperatures over the last 14 days of the test period. The results are inconclusive. The measured strength of the bottommost brick, embedded in newly formed snow ice, is roughly the same as that of the snow ice cut from the ice cover as shown in Table 2. The brick immediately above it gave a measured strength nearly that of the other CFG ice measured in this study, while the remaining bricks, up to about $25 \mathrm{~cm}$ above the final ice surface, gave consistently lower strength values than any of the other CFG ice samples, except the embedded and partially recrystallized sample. Further investigation of these observations would be useful to try to identify the cause of this apparent anomaly.

\section{PART 3. MICROSTRUCTURE}

Solid state sintering has received considerable attention in recent years because of its importance in the manufacture of metals, ceramics, and cements. The ideal raw material is fine-grained (to increase the speed of sintering or lower the temperature for effective

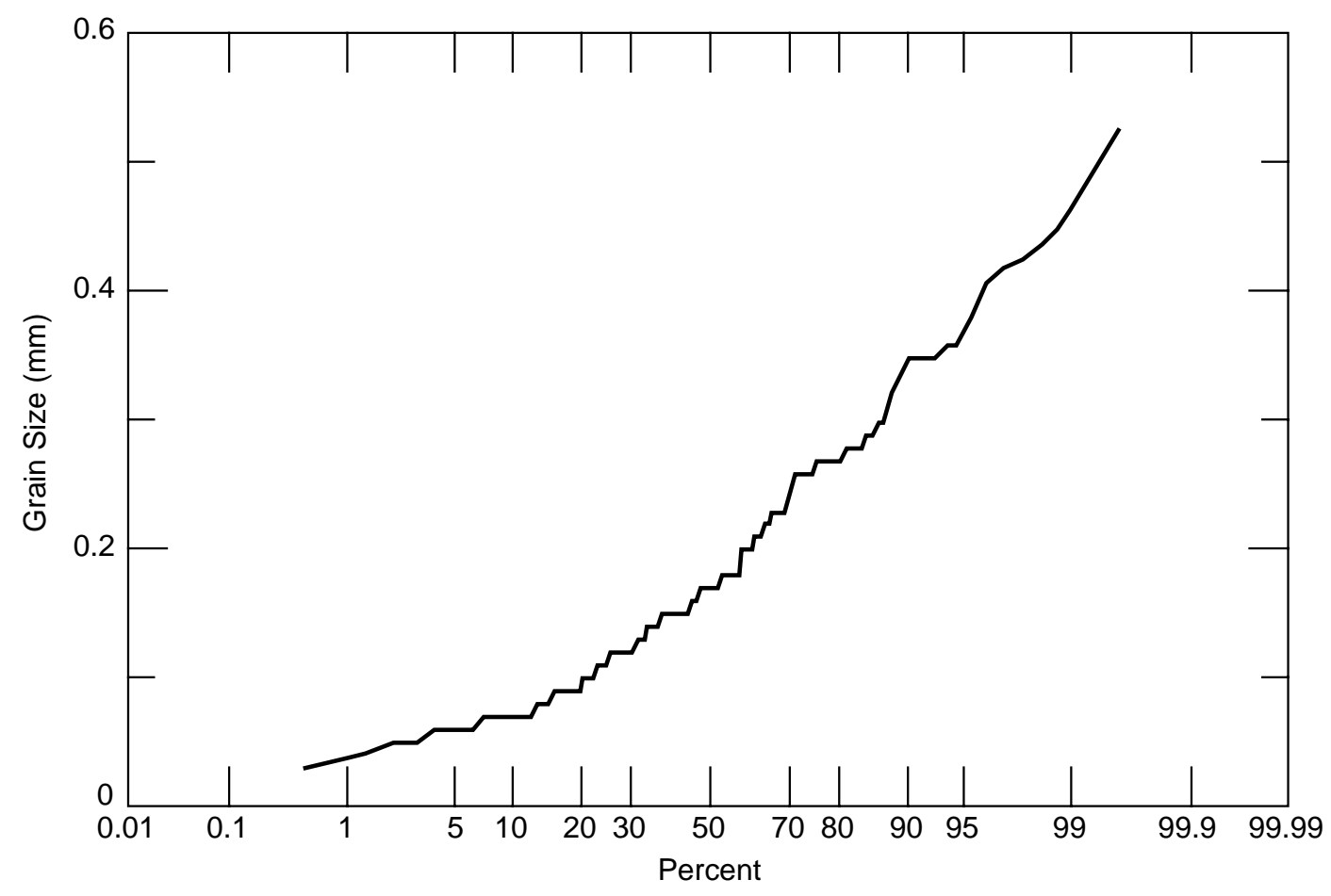

Figure 15. Grain size distribution of CFG ice. Dimensions were obtained using the linear intercept method. 


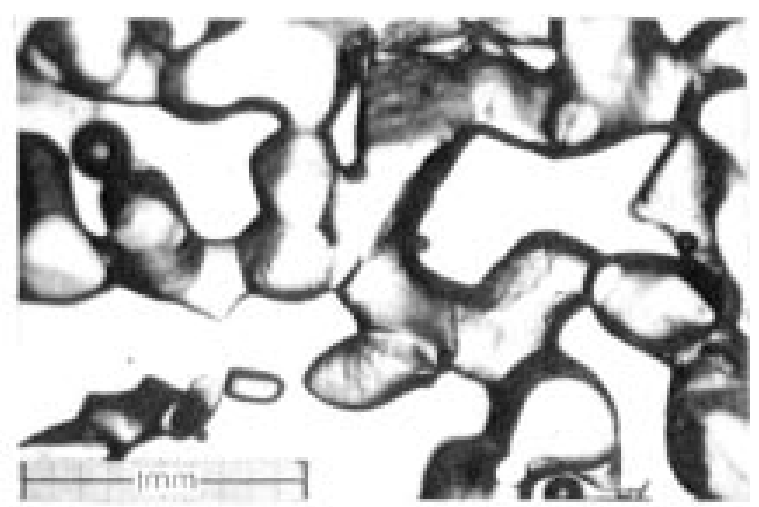

a. The original snow (density $0.35 \mathrm{gm} / \mathrm{cm}^{2}$ ).

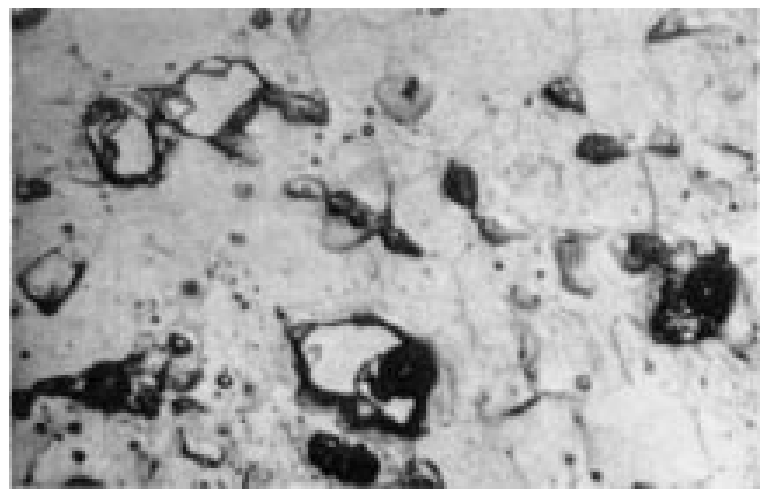

c. Further compressed to a density of $0.78 \mathrm{gm} / \mathrm{cm}^{2}$.

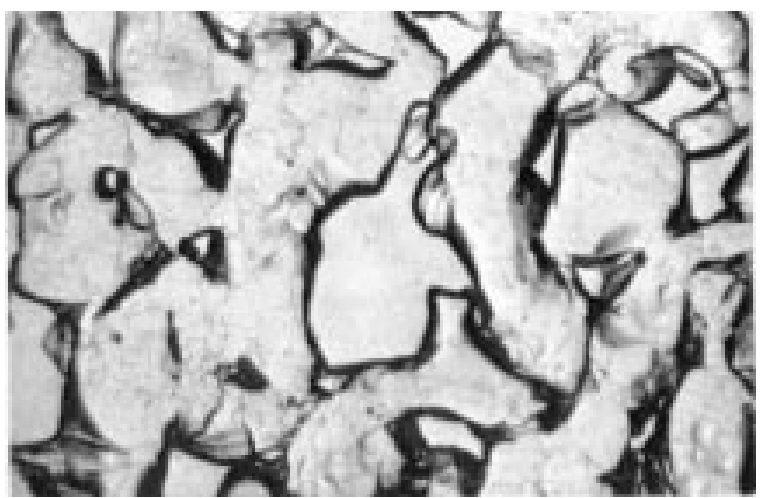

b. The same snow compressed to a density of 0.64 $\mathrm{gm} / \mathrm{cm}^{2}$.

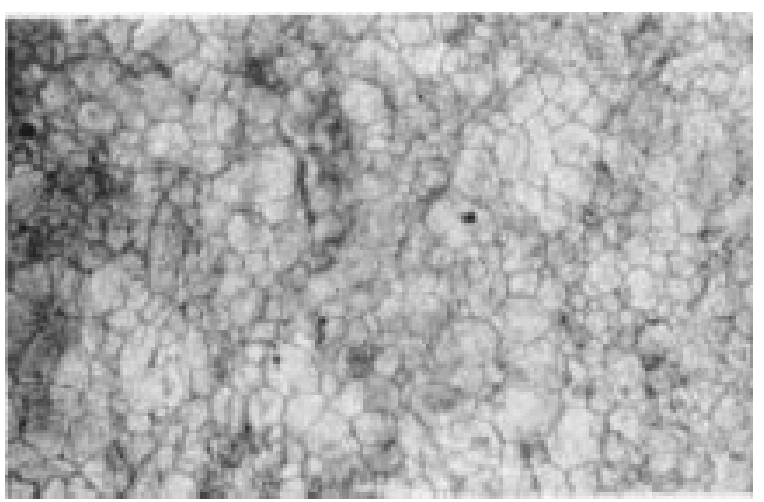

d. Final compaction to density of ice. (From Yosida 1963.)

Figure 16. Microstructure of snow at various stages of compaction.

sintering or both) and uniform (so that large grains are not present to grow at the expense of smaller ones). Hot pressing, which is the process used here, is often used because it reduces defect size and grain growth over the standard method of forming the material under pressure followed by heating to complete the sintering (Moya et al. 1987).

Table 1 shows the grain size distribution of the undisturbed snow we used as well as the same snow after it had been stirred with a wire whisk. The size distribution does not differ greatly between these two, with about $75 \%$ of the material showing a particle size greater than $0.84 \mathrm{~mm}$. We examined thin sections of representative samples of the CFG ice we made to confirm that the crystal size distribution was uniform and to determine whether there were any obvious defects.

\section{Equipment and procedures}

Using a bandsaw, we cut a small slab of CFG ice about $7 \mathrm{~mm}$ thick from the crescents left after taking samples for uniaxial compressive testing. The cutting pattern is shown in Figure 2. The sample was then frozen onto a glass slide by warming the slide slightly. Samples were also taken from the natural snow ice collected from a pond and from clear S2 ice from Lake Superior. When the sample was securely frozen to the glass, it was trimmed on the bandsaw to a thickness of about $1 \mathrm{~mm}$. It was then planed using sanding screen and finally smoothed using a razor blade.

The slides were then examined using a compound microscope, fitted with polarizing filters, with $3.5 \times$ and $10 \times$ objectives. Photographs were made of both horizontal sections and vertical sections. A 1-mm stage micrometer was also photographed at both magnifications for later use in measuring crystal size. Crystal size was measured by the linear intersect method. Twenty measurements were taken on both horizontal and vertical transects of the photograph.

\section{Results}

Microscopic examination of thin sections of our compacted material showed almost no crystal as large as $0.84 \mathrm{~mm}$, and those that were appeared to be a 
product of recrystallization. The grain shape was remarkably equidimensional and the bubbles small and uniformly distributed. Figure 14 is a photograph of a typical thin section of CFG ice, and Figure 15 shows a graph of the grain size distribution.

\section{Discussion}

Ebinuma and Maeno (1984), compacting ice spheres about $0.2 \mathrm{~mm}$ in diameter, found that the spheres appeared as individual particles up to a density of about $700 \mathrm{~kg} / \mathrm{m}^{3}$. By the time the material reached a density of $750 \mathrm{~kg} / \mathrm{m}^{3}$, the individual particles had coalesced into a more or less uniform consistency. Natural snow strength increases with density all the way to ice of 910-920. (See Kovacs 1993.) Up to this critical density, densification is achieved largely by rearrangement of the particles. At densities greater than this, further densification results from plastic deformation, which leads to gradual extinction of the pores and creation of a uniform, fine-grained crystal structure.

In a similar study Yosida (1963) describes a series of snow-compaction experiments in which low-density natural snow is compressed using a 10 -ton press whose speed range varied from 1.0 to $1.8 \mathrm{~mm} / \mathrm{min}$. to investigate the effect of very high compaction pressures. In this study the original material was snow with irregular grain sizes ranging from about 0.5 to $1.0 \mathrm{~mm}$ (see Fig. 16a), and the author used unconfined columns of snow up to $15 \mathrm{~cm}$ high. Yosida made thin sections of the snow column at various stages in the compaction process. Photos of these samples are shown on Figure 16. This snow, compacted to a density of $640 \mathrm{~kg} / \mathrm{m}^{3}$ (shown in Fig. 16b), shows signs of cracking within the individual crystals. At a density of 780, at the low end of the density range of our CFG ice, the crystal structure was metamorphosed into a fabric with generally regular grains about 0.2 to $0.5 \mathrm{~mm}$ in diameter. With additional pressure, these crystals are further reduced in size.

This process appears to be at work in the CFG ice since its grain size averaged about $0.2 \mathrm{~mm}$ (see Fig. 15 ), roughly $25 \%$ of the grain size of our parent material. It is interesting to note that the fine-grained structure of the final product is a result of the subdivision of much larger grains in the original material. There is great similarity in crystal shape and size between the CFG ice shown in Figure 14 and Yosida's compacted snow at a density of $780 \mathrm{~kg} / \mathrm{m}^{3}$ (Fig. 16c). The much smaller crystals in his final section at the density of ice were produced by a much higher load (not given) than we used. It is interesting to note that there are no bubbles visible.

Concerning why CFG ice is so slow to recrystallize,
Abele and Gow (1976) found that snow temperature at the time of compaction exerts a considerable influence on the microstructure of the resulting material. At snow temperatures lying somewhere between -5 and $-10^{\circ} \mathrm{C}$, the temperature range including most of our snow samples, ice made by compaction at high stresses (around $6.87 \mathrm{MPa}$ ) is not as quick to recrystallize as it is above $-5^{\circ}$ or below $10^{\circ}$.

\section{APPLICATIONS}

The bricks fabricated in this study are too small to be widely useful in most construction roles. A much larger building unit would be needed for field applications. The bricks should be as large as possible to minimize the time of construction but still be small enough so that one person can handle them easily. A brick size about 0.15 to $0.2 \mathrm{~m}^{2}$ in surface area and 0.1 to $0.15 \mathrm{~m}$ thick, for example, weighing about $25 \mathrm{~kg}$, would be large enough that fairly extensive projects like retaining walls and pavements could be constructed rapidly with minimal manpower. In order to ensure uniform high density throughout the brick, the thickness of the snow mass normal to the stroke should be the smallest dimension. Therefore, this brick would require a compressive force of about 130 tonnes distributed evenly across the $30-\times 60-\mathrm{cm}$ face. In theory, this is not a problem; however, in practice, such a hydraulic press is very large, and seldom routinely available.

Such bricks should also be strong enough to endure repeated traffic or other loads expected in their final application. In areas where water is present, either salt or fresh, they should be impermeable for maximum useful life.

A round shape would be best from the standpoint of reducing edge effects, and the form would be simple to make, requiring little reinforcement. It would not, however, be the best shape for a building block. On the other hand, a square or rectangular shape, ideal for paving or building, would require a form that was very strongly reinforced, and probably heavy and difficult to handle, and edge effects might introduce flaws and inhomogeneities that we did not find in our round bricks. A compromise such as a hexagonal or octagonal shape might prove the best choice.

In terms of the energy cost of compaction to produce ice as compared with melting snow and refreezing it, it is clear that compaction is by far the more efficient method. For example, to fabricate a block with a density of 860 and size of $30 \times 60 \times 15 \mathrm{~cm}$, weighing $23 \mathrm{~kg}$, the required compression pressure would be 130 tonnes 
(143 tons). The energy required for the hydraulic pump for a press of this magnitude would draw around $2 \mathrm{kw}$ of electric power at maximum pressure. Roughly 20 blocks could be made in an hour for a maximum energy cost of less than $2 \mathrm{kwh}(7.2 \mathrm{mj})$. This is almost enough energy to melt one of these bricks, or to increase the water content of the total volume of snow to almost $5 \%$.

While snow with 5\% moisture content would be an excellent material for conventional snow-compaction methods, there are a number of problems with producing it in very cold areas:

- Numerous techniques have been tested in Antarctica and in Greenland with very modest success. It appears to be a formidable problem to achieve uniform distribution of the heat through the surface snow layer, and this results in very uneven strength of the compacted layer.

- The very great amounts of heat required to overcome the latent heat of fusion of ice to produce water vastly increase the energy cost of melting snow either to raise the moisture content of the snow cover or to produce bulk water for application as spray or steam.

- The energy cost goes far beyond that of warming the snow, as the subsequent processing would involve numerous passes with rollers, planes, and similar equipment.

- Even under optimum conditions it is difficult to achieve a uniform compacted snow layer with a density as high as $700 \mathrm{~kg} / \mathrm{m}^{3}$, and the resulting material is not as strong as natural ice, whose strength marks the lower bound of CFG ice.

- Since conventionally produced compacted snow is porous, it is still subject to such problems as depth hoar development, and is unsuitable for use in areas where water infiltration, especially salt water, is likely.

We used a hydraulic press in this study to compact the snow because it was convenient, available, and easy to monitor. Other techniques may be used with equal success, such as a lever arm, perhaps in conjunction with a hydraulic press or a mobile roller assembly to produce a continuous sheet of compacted material.

Equipment limitations may dictate the maximum load applicable by hydraulic or mechanical apparatus. Another means of achieving a great force is by dropping a dead weight from various heights. A 500-kg weight, for example, dropped from a height of $3 \mathrm{~m}$ will produce an impact load from about 25 up to nearly 100 tons, depending on sinkage. If the resulting brick has the same properties as one compressed to the same degree but over a longer time, this compaction method may prove to be the easiest and most practical, perhaps for all degrees of compaction, although the very high loading rate might not prove as effective as some slower means.

\section{CONCLUSIONS}

In terms of the original thrust of the project - to develop a low-energy method of producing highstrength compacted snow for construction purposesthe results reported here show that CFG ice is a strongenough construction material for most paving applications, and more than strong enough for building walls, shelters, and so forth.

Since the initial density of the bricks was in the ice range, i.e., the bubbles were isolated, many problems are minimized, such as those associated with vapor movement, e.g., depth hoar, as well as with percolation of salt water or other fluids. The material appears to be stable in a thermal gradient as well.

The CFG ice produced in this study is interesting for a number of reasons. First, the means of its compaction (using extremely high compaction pressures) appears to have completed the sintering process at the time of fabrication, as there is no evidence of increasing strength, either compressive or flexural, with time. Second, the very small grain size resulting from the high compaction pressures appears to be stable, at least in the conditions prevailing in this study. In most cases the crystal sizes do not appear to have changed appreciably even after 20 days. This further supports the idea that the sintering process is complete at the time of fabrication. Third, the material is very strong and seems to be tough, although fracture toughness was not measured. The small grain size may account for this, as crack propagation would be inhibited both by this and by the small, uniformly distributed bubbles.

\section{LITERATURE CITED}

Abele, G., and A.J. Gow (1976) Compressibility characteristics of compacted snow. U.S. Army Cold Regions Research and Engineering Laboratory, CRREL Report 76-21.

Abele, G., R.O. Ramseier, and A.F. Wuori (1968) Design criteria for snow runways. U.S. Army Cold Regions Research and Engineering Laboratory, Technical Report 212.

Butkovich, T.R. (1962) Studies of the age hardening of processed snow. U.S. Army Cold Regions Research and Engineering Laboratory, Research Report 99.

Ebinuma, T., and N. Maeno (1984) Experimental 
studies on densification and pressure-sintering of ice. In Proceedings of Symposium on Snow and Ice Processes at the Earth's Surface, Sapporo, Japan, September 2-7, 1984. Also appears in the 1985 Annals of Glaciology, 6: 83-86.

Gold, L.W. (1977) Engineering properties of freshwater ice. Journal of Glaciology, 19(81): 197-212.

Gow, A.J. (1977) Flexural strength of ice on temperate lakes. Journal of Glaciology, 19(81): 247-256.

Hawkes, I., and M. Mellor (1972) Deformation and fracture of ice under uniaxial stress. Journal of Glaciology, 11(61): 103-131.

Kovacs, A. (1993) Axial double-ball test versus uniaxial unconfined compression test for measuring the compressive strength of freshwater and sea ice. U.S. Army Cold Regions Research and Engineering Laboratory, CRREL Report 93-25.

Kuehn, G.A., E.M. Schulson, D.E. Jones, and J. Zhang (1992) The compressive strength of ice cubes of different sizes. OMAE Proceedings, Vol. IV, Arctic/Polar Technology, p. 349-356.

Lavrov, V.V. (1969) Deformation and Strength of Ice (Defoematsiia i prochnost' l'da). Gidrometizdat, Leningrad, 1969. Translated by T. Pelz, Israel Program for Scientific Translations. Jerusalem, 1971.
Moya, J.S., C. Baudin, and P. Miranzo (1987) Sintering. Encyclopedia of Physical Science and Technology (R.A. Myers, Ed.), vol. 12, p. 699-712. Boston: Academic Press.

Ramseier, R.O., and G.W. Sander (1966) Temperature dependence and mechanism of sintering. U.S. Army Cold Regions Research and Engineering Laboratory, Research Report 189.

Schulson, E.M., and N.P. Cannon (1984) The effect of grain size on the compressive strength of ice. In Proceedings of the IAHR Symposium in Ice, Hamburg, Germany. International Association of Hydraulic Research, vol. 1, p. 29-38.

Schwarz, J., and W.F. Weeks (1977) Engineering properties of sea ice. Journal of Glaciology, 19(81): 499-531.

Stearns, S.R. (1964) Flexural properties of snow and snow-ice. U.S. Army Cold Regions Research and Engineering Laboratory, Special Report 56.

Yakovlev, G.N. (1971) Manual for Examination of the Physical and Mechanical Properties of Ice. Leningrad: Arctic and Antarctic Research Institute (in Russian).

Yosida, Z. (1963) Physical properties of snow. Ice and Snow (W.D. Kingery, Ed.), p. 485-527. Cambridge, Massachusetts: MIT Press. 


\section{APPENDIX A: FABRICATION INFORMATION FOR ALL SAMPLES}

Compaction data

\begin{tabular}{|c|c|c|c|c|c|c|c|c|}
\hline $\begin{array}{l}\text { Run } \\
\text { no. }\end{array}$ & $\begin{array}{l}\text { Compaction } \\
\text { pressure } \\
\text { (MPa) }\end{array}$ & $\begin{array}{l}\text { Pressure } \\
\text { held } \\
\text { (s) }\end{array}$ & $\begin{array}{l}\text { Compa } \\
\text { height } \\
(\mathrm{cm})\end{array}$ & $\begin{array}{l}d \\
\text { Density } \\
\left(\mathrm{kg} / \mathrm{m}^{3}\right)\end{array}$ & $\begin{array}{l}\text { temp } \\
\left({ }^{\circ} \mathrm{C}\right)\end{array}$ & $\begin{array}{l}\text { Room } \\
\text { temp } \\
\left({ }^{\circ} \mathrm{C}\right)\end{array}$ & $\begin{array}{l}\text { Sinter } \\
\text { temp } \\
\left({ }^{\circ} \mathrm{C}\right)\end{array}$ & $\begin{array}{l}\text { Snow } \\
\text { Storage } \\
\text { condition }\end{array}$ \\
\hline 1 & 6.87 & 30 & 4.9 & 834 & -2 & -10 & n.m. & $\mathrm{t} \& \mathrm{p}$ test \\
\hline 2 & 5.89 & 0 & 5.2 & 787 & -3 & -10 & n.m. & $\mathrm{t} \& \mathrm{p}$ test \\
\hline 3 & 4.91 & 0 & 5.5 & 740 & -3 & -10 & n.m. & $t \& p$ test \\
\hline 4 & 3.92 & 0 & 6.2 & 712 & -3 & -10 & n.m. & $\mathrm{t} \& \mathrm{p}$ test \\
\hline 5 & 6.87 & 0 & 4.9 & 801 & -3 & -10 & n.m. & $t \& p$ test \\
\hline 6 & 5.89 & 30 & 4.9 & 814 & -3 & -10 & n.m. & $\mathrm{t} \& \mathrm{p}$ test \\
\hline 7 & 4.91 & 30 & 5.2 & 806 & -4 & -10 & n.m. & $\mathrm{t} \& \mathrm{p}$ test \\
\hline 8 & 3.92 & 30 & 5.1 & 763 & -4 & -10 & n.m. & $t \& p$ test \\
\hline 9 & 6.87 & 60 & 4.5 & 859 & -4 & -10 & n.m. & $\mathrm{t} \& \mathrm{p}$ test \\
\hline 10 & 5.89 & 60 & 5.3 & 842 & -4 & -10 & n.m. & $t \& p$ test \\
\hline 11 & 4.91 & 60 & 5.2 & 806 & -4 & -10 & n.m. & $t \& p$ test \\
\hline 12 & 3.92 & 60 & 5.7 & 773 & -4 & -10 & n.m. & $t \& p$ test \\
\hline 13 & 6.87 & 30 & 4.2 & 825 & -2 & -25 & -12 & f20 \\
\hline 14 & 6.87 & 30 & 4.6 & 823 & -2 & -25 & -12 & c20 \\
\hline 15 & 6.87 & 30 & 4.55 & 809 & -2 & -25 & -12 & f20 \\
\hline 16 & 6.87 & 30 & 4.65 & 821 & -1.5 & -25 & -12 & c20 \\
\hline 17 & 6.87 & 30 & 5.2 & 823 & -1.5 & -25 & -12 & $\mathrm{f} 20$ \\
\hline 18 & 6.87 & 30 & 4.8 & 840 & -1.5 & -25 & -12 & f20 \\
\hline 19 & 6.87 & 30 & 4.7 & 845 & -1.5 & -15 & -9.5 & c20 \\
\hline 20 & 6.87 & 30 & 4.5 & 831 & -1.5 & -15 & -9.5 & $\mathrm{f} 20$ \\
\hline 21 & 6.87 & 30 & 5.05 & 827 & -1.5 & -15 & -9.5 & $\mathrm{f} 20$ \\
\hline 22 & 6.87 & 30 & 4.8 & 824 & -1.5 & -15 & -9.5 & f20 \\
\hline 23 & 6.87 & 30 & 4.75 & 840 & -1.5 & -15 & -9.5 & f20 \\
\hline 24 & 6.87 & 30 & 4.8 & 827 & -1.5 & -15 & -9.5 & c20 \\
\hline 25 & 6.87 & 30 & 4.65 & 847 & -2 & -10 & -8.5 & c20 \\
\hline 26 & 6.87 & 30 & 4.6 & 820 & -2 & -10 & -8.5 & $\mathrm{f} 20$ \\
\hline 27 & 6.87 & 30 & 4.55 & 838 & -2 & -10 & -8.5 & f20 \\
\hline 28 & 6.87 & 30 & 4.6 & 882 & -2 & -10 & -8.5 & f20 \\
\hline 29 & 6.87 & 30 & 4.65 & 847 & -2 & -10 & -8.5 & $\mathrm{f} 20$ \\
\hline 30 & 6.87 & 30 & 5.05 & 834 & -2 & -10 & -8.5 & c20 \\
\hline 31 & 6.87 & 30 & 4.65 & 866 & -2 & ambient & -6 & pond \\
\hline 32 & 6.87 & 30 & 4.7 & 875 & -2 & ambient & -6 & pond \\
\hline 33 & 6.87 & 30 & 4.45 & 872 & -2 & ambient & -6 & pond \\
\hline 34 & 6.87 & 30 & 4.75 & 875 & -2 & ambient & -6 & pond \\
\hline 35 & 6.87 & 30 & 5.05 & 881 & -2 & ambient & -6 & pond \\
\hline 36 & 6.87 & 30 & 4.75 & 877 & -2 & ambient & -6 & pond \\
\hline 37 & 6.87 & 30 & 4.95 & 879 & -2 & ambient & -5 & pond \\
\hline 38 & 6.87 & 30 & 5 & 886 & -2 & ambient & -5 & pond \\
\hline 39 & 6.87 & 30 & 4.75 & 864 & -2 & ambient & -5 & pond \\
\hline 40 & 6.87 & 30 & 5 & 880 & -2 & ambient & -5 & pond \\
\hline 41 & 6.87 & 30 & 5.6 & 866 & -2 & ambient & -5 & pond \\
\hline 42 & 6.87 & 30 & 5.2 & 833 & -2 & ambient & -5 & pond \\
\hline 43 & 6.87 & 30 & 5.1 & 815 & -2.8 & -25 & -16 & $\mathrm{f} 10$ \\
\hline 44 & 6.87 & 30 & 4.9 & 832 & -5 & -15 & -15 & $\mathrm{f} 10$ \\
\hline 45 & 6.87 & 30 & 4.6 & 824 & -7.8 & -10 & -15 & c10 \\
\hline 46 & 6.87 & 30 & 4.8 & 825 & -7.8 & -25 & -15 & $\mathrm{f} 10$ \\
\hline 47 & 6.87 & 30 & 5.05 & 803 & -7.8 & -15 & -15 & $\mathrm{f} 10$ \\
\hline 48 & 6.87 & 30 & 4.8 & 814 & -7.8 & -10 & -15 & $\mathrm{f} 10$ \\
\hline 49 & 6.87 & 30 & 5.05 & 813 & -7.8 & -25 & -13 & broken \\
\hline 50 & 6.87 & 30 & 5.1 & 820 & -7.8 & -15 & -13 & c10 \\
\hline 51 & 6.87 & 30 & 5.05 & 828 & -7.8 & -10 & -13 & c10 \\
\hline 52 & 6.87 & 30 & 4.75 & 812 & -7.8 & -25 & -12 & $\mathrm{f} 10$ \\
\hline 53 & 6.87 & 30 & 5.05 & 822 & -8.2 & -15 & -12 & f10 \\
\hline 54 & 6.87 & 30 & 5.2 & 822 & -11 & -10 & -11 & $\mathrm{f} 10$ \\
\hline 55 & 6.87 & 30 & 5.2 & 816 & -11 & -25 & -11 & c10 \\
\hline 56 & 6.87 & 30 & 5.3 & 830 & -11 & -15 & -11 & $\mathrm{f} 10$ \\
\hline
\end{tabular}




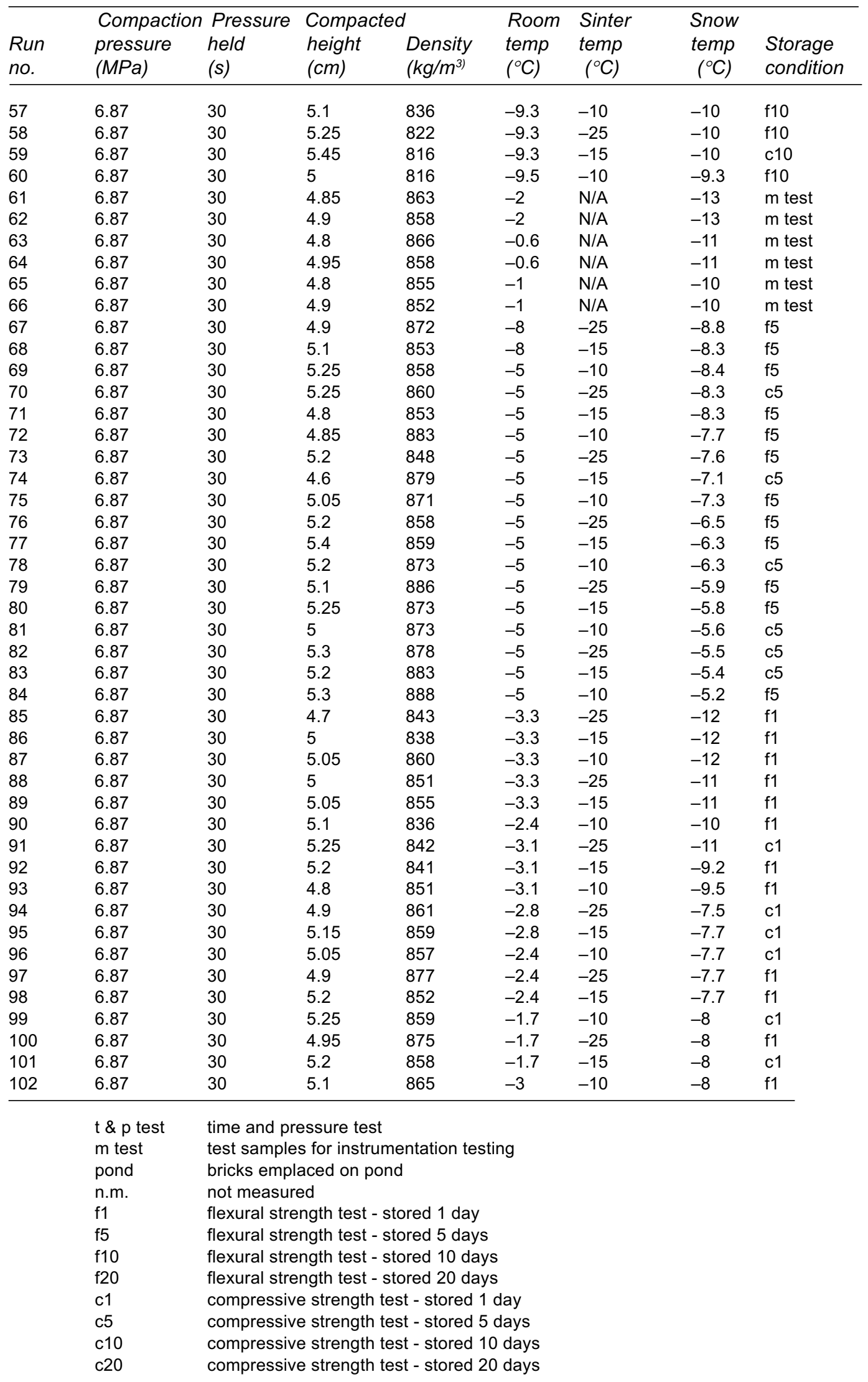


APPENDIX B: UNCONFINED COMPRESSIVE STRENGTH DATA FOR ALL SAMPLES TESTED

Calculated compressive strength of compacted snow samples

\begin{tabular}{|c|c|c|c|c|c|c|c|}
\hline Date & $\begin{array}{l}\text { Sample } \\
\text { no. }\end{array}$ & $\begin{array}{l}\text { Density } \\
\left(\mathrm{kg} / \mathrm{m}^{3}\right)\end{array}$ & $\begin{array}{l}\text { Storage } \\
\text { temp }\left({ }^{\circ} \mathrm{C}\right)\end{array}$ & $\begin{array}{l}\text { Storage } \\
\text { time } \\
\text { (days) }\end{array}$ & $\begin{array}{l}\text { Compressive } \\
\text { strength } \\
\text { (MPa) }\end{array}$ & $\begin{array}{l}\text { Sample } \\
\text { mean }\end{array}$ & Sample SD \\
\hline \multirow[t]{4}{*}{ 3-Feb } & 96 & 860 & -10 & 1 & 4.40 & & \\
\hline & $96 b$ & & & 1 & 11.03 & & \\
\hline & $96 c$ & & & 1 & 10.81 & & \\
\hline & $96 d$ & & & 1 & 9.05 & & \\
\hline \multirow[t]{4}{*}{ 3-Feb } & 99 & 860 & -10 & 1 & 10.12 & & \\
\hline & $99 b$ & & & 1 & 7.68 & & \\
\hline & $99 c$ & & & 1 & 10.32 & & \\
\hline & $99 d$ & & & 1 & 9.97 & 9.17 & 2.20 \\
\hline \multirow[t]{4}{*}{ 3-Feb } & 95 & 860 & -15 & 1 & 11.95 & & \\
\hline & $95 b$ & & & 1 & 7.29 & & \\
\hline & $95 c$ & & & 1 & 10.87 & & \\
\hline & $95 d$ & & & 1 & 11.99 & & \\
\hline \multirow{4}{*}{ 3-Feb } & 101 & 860 & -15 & 1 & 9.63 & & \\
\hline & $101 b$ & & & 1 & 13.08 & & \\
\hline & $101 \mathrm{c}$ & & & 1 & 9.02 & & \\
\hline & $101 d$ & & & 1 & 9.90 & 10.47 & 1.88 \\
\hline \multirow[t]{4}{*}{ 3-Feb } & 91 & 840 & -25 & 1 & 13.04 & & \\
\hline & $91 b$ & & & 1 & 9.22 & & \\
\hline & $91 \mathrm{c}$ & & & 1 & 13.65 & & \\
\hline & $91 d$ & & & 1 & 12.14 & & \\
\hline \multirow[t]{4}{*}{ 3-Feb } & 94 & 860 & -25 & 1 & 13.32 & & \\
\hline & $94 b$ & & & 1 & 8.00 & & \\
\hline & $94 c$ & & & 1 & 11.91 & & \\
\hline & $94 d$ & & & 1 & 11.34 & 11.58 & 2.01 \\
\hline \multirow[t]{4}{*}{$2-F e b$} & 78 & 870 & -10 & 5 & 11.38 & & \\
\hline & $78 b$ & & & 5 & 10.74 & & \\
\hline & $78 c$ & & & 5 & 10.09 & & \\
\hline & $78 d$ & & & 5 & 11.16 & & \\
\hline \multirow[t]{4}{*}{ 2-Feb } & 81 & 870 & -10 & 5 & 10.10 & & \\
\hline & $81 b$ & & & 5 & 9.18 & & \\
\hline & $81 c$ & & & 5 & 5.24 & & \\
\hline & $81 d$ & & & 5 & 8.11 & 9.50 & 2.02 \\
\hline \multirow[t]{4}{*}{2 -Feb } & 74 & 880 & -15 & 5 & 9.55 & & \\
\hline & $74 b$ & & & 5 & 8.20 & & \\
\hline & $74 c$ & & & 5 & 12.86 & & \\
\hline & $74 d$ & & & 5 & 11.49 & & \\
\hline \multirow[t]{4}{*}{ 2-Feb } & 83 & 880 & -15 & 5 & 8.54 & & \\
\hline & $83 b$ & & & 5 & 5.24 & & \\
\hline & $83 c$ & & & 5 & 13.11 & & \\
\hline & $83 d$ & & & 5 & 11.41 & 10.05 & 2.68 \\
\hline \multirow[t]{4}{*}{ 2-Feb } & 70 & 860 & -25 & 5 & 13.29 & & \\
\hline & $70 b$ & & & 5 & 12.47 & & \\
\hline & $70 c$ & & & 5 & 11.13 & & \\
\hline & $70 d$ & & & 5 & 13.41 & & \\
\hline \multirow[t]{4}{*}{ 2-Feb } & 82 & 880 & -25 & 5 & 12.38 & & \\
\hline & $82 b$ & & & 5 & 11.52 & & \\
\hline & $82 c$ & & & 5 & 12.75 & & \\
\hline & $82 d$ & & & 5 & 12.14 & 12.39 & 0.79 \\
\hline \multirow[t]{4}{*}{ 30-Jan } & 45 & 820 & -10 & 10 & 7.11 & & \\
\hline & $45 b$ & & & 10 & 11.03 & & \\
\hline & $45 c$ & & & 10 & 10.50 & & \\
\hline & $45 d$ & & & 10 & 9.78 & & \\
\hline \multirow[t]{2}{*}{ 30-Jan } & 51 & 830 & -10 & 10 & 10.31 & & \\
\hline & $51 b$ & & & 10 & 10.88 & & \\
\hline
\end{tabular}




\begin{tabular}{|c|c|c|c|c|c|c|c|}
\hline Date & $\frac{\text { Sample }}{\text { no. }}$ & $\frac{\text { Density }}{\mathrm{kg} / \mathrm{m}^{\wedge}}$ & $\frac{\text { Storage }}{\text { temp }}$ & $\begin{array}{l}\text { Storage } \\
\frac{\text { time }}{\text { (days) }}\end{array}$ & $\begin{array}{l}\text { Compressive } \\
\text { strength } \\
\mathrm{MPa}\end{array}$ & $\frac{\text { Sample }}{\text { mean }}$ & Sample SD \\
\hline & $51 \mathrm{c}$ & & & 10 & 10.85 & & \\
\hline & $51 \mathrm{~d}$ & & & 10 & 3.34 & 9.22 & 2.70 \\
\hline \multirow[t]{4}{*}{ 30-Jan } & 50 & 820 & -15 & 10 & 11.99 & & \\
\hline & $50 b$ & & & 10 & 11.61 & & \\
\hline & $50 c$ & & & 10 & 10.50 & & \\
\hline & $50 d$ & & & 10 & 11.37 & & \\
\hline \multirow[t]{4}{*}{ 30-Jan } & 59 & 820 & -15 & 10 & 12.83 & & \\
\hline & $59 b$ & & & 10 & 11.92 & & \\
\hline & $59 c$ & & & 10 & 11.56 & & \\
\hline & $59 c$ & & & 10 & 11.24 & 11.63 & 0.67 \\
\hline \multirow[t]{4}{*}{ 30-Jan } & 55 & 820 & -25 & 10 & 7.70 & & \\
\hline & $55 b$ & & & 10 & 13.41 & & \\
\hline & $55 c$ & & & 10 & 11.50 & & \\
\hline & $55 d$ & & & 10 & 11.24 & 10.96 & 2.38 \\
\hline \multirow[t]{4}{*}{$\overline{15-\mathrm{Feb}}$} & $25 a$ & 850 & -10 & 20 & 13.12 & & \\
\hline & $25 b$ & & & 20 & 4.31 & & \\
\hline & $25 c$ & & & 20 & 8.26 & & \\
\hline & $25 d$ & & & 20 & 10.36 & & \\
\hline \multirow[t]{4}{*}{$15-\mathrm{Feb}$} & $30 a$ & 830 & -10 & 20 & 10.27 & & \\
\hline & $30 b$ & & & 20 & 10.59 & & \\
\hline & $30 c$ & & & 20 & 9.50 & & \\
\hline & $30 d$ & & & 20 & 10.55 & 9.62 & 2.54 \\
\hline \multirow[t]{4}{*}{ 15-Feb } & $19 a$ & 840 & -15 & 20 & 9.83 & & \\
\hline & $19 b$ & & & 20 & 12.42 & & \\
\hline & $19 c$ & & & 20 & 11.37 & & \\
\hline & $19 d$ & & & 20 & 9.48 & & \\
\hline \multirow[t]{4}{*}{ 15-Feb } & $24 a$ & 830 & -15 & 20 & 11.55 & & \\
\hline & $24 b$ & & & 20 & 11.30 & & \\
\hline & $24 c$ & & & 20 & 11.04 & & \\
\hline & $24 d$ & & & 20 & 10.75 & 10.97 & 0.95 \\
\hline \multirow[t]{4}{*}{ 15-Feb } & $14 a$ & 820 & -25 & 20 & 13.93 & & \\
\hline & $14 b$ & & & 20 & 12.55 & & \\
\hline & $14 c$ & & & 20 & 13.69 & & \\
\hline & $14 d$ & & & 20 & 12.29 & & \\
\hline \multirow{4}{*}{$15-\mathrm{Feb}$} & $16 a$ & 820 & -25 & 20 & 8.64 & & \\
\hline & $16 b$ & & & 20 & 10.69 & & \\
\hline & $16 c$ & & & 20 & 11.10 & & \\
\hline & $16 d$ & & & 20 & 12.45 & 11.92 & 1.73 \\
\hline \multirow[t]{4}{*}{$\overline{9-F e b}$} & $15 \mathrm{~cm} \mathrm{a}$ & & ambient & $\mathrm{N} / \mathrm{A}$ & 2.63 & & \\
\hline & $15 \mathrm{~cm} \mathrm{~b}$ & & & $\mathrm{~N} / \mathrm{A}$ & 3.23 & & \\
\hline & $15 \mathrm{~cm} \mathrm{c}$ & & & N/A & 2.37 & & \\
\hline & $15 \mathrm{~cm} \mathrm{~d}$ & & & $N / A$ & 3.40 & & \\
\hline \multirow[t]{4}{*}{$9-F e b$} & $50 \mathrm{~cm} \mathrm{a}$ & 880 & ambient & $\mathrm{N} / \mathrm{A}$ & 1.54 & & \\
\hline & $50 \mathrm{~cm} \mathrm{~b}$ & & & $\mathrm{~N} / \mathrm{A}$ & 5.35 & & \\
\hline & $50 \mathrm{~cm} \mathrm{c}$ & & & $\mathrm{N} / \mathrm{A}$ & 4.39 & & \\
\hline & $50 \mathrm{~cm} \mathrm{~d}$ & & & $\mathrm{~N} / \mathrm{A}$ & 3.92 & 3.35 & 1.21 \\
\hline \multirow[t]{7}{*}{$\overline{14-F e b}$} & Sup1 & 920 & ambient & $\mathrm{N} / \mathrm{A}$ & 2.19 & & \\
\hline & Sup2 & & & $\mathrm{N} / \mathrm{A}$ & 1.43 & & \\
\hline & Sup3 & & & $\mathrm{N} / \mathrm{A}$ & 1.16 & & \\
\hline & Sup4 & & & $\mathrm{N} / \mathrm{A}$ & 1.63 & & \\
\hline & Sup5 & & & $\mathrm{N} / \mathrm{A}$ & 2.04 & & \\
\hline & Sup6 & & & $\mathrm{N} / \mathrm{A}$ & 1.73 & & \\
\hline & Sup7 & & & $\mathrm{N} / \mathrm{A}$ & 1.68 & 1.69 & 0.35 \\
\hline
\end{tabular}


APPENDIX C: FLEXURAL STRENGTH DATA FOR ALL SAMPLES TESTED

Flexural test data

\begin{tabular}{|c|c|c|c|c|c|c|c|c|c|c|}
\hline $\begin{array}{l}\text { Sample } \\
\text { no. }\end{array}$ & $\begin{array}{l}\text { Storage } \\
\text { time } \\
\text { (days) }\end{array}$ & $\begin{array}{l}\text { Storage } \\
\text { temp } \\
\left({ }^{\circ} \mathrm{C}\right)\end{array}$ & $\begin{array}{l}\text { Density } \\
\left(\mathrm{kg} / \mathrm{m}^{3}\right)\end{array}$ & $\begin{array}{l}\text { Disk } \\
\text { thickness } \\
\text { (cm) }\end{array}$ & $\begin{array}{l}\text { Maximum } \\
\text { deflection } \\
(\mathrm{mm})\end{array}$ & $\begin{array}{l}\text { Maximum } \\
\text { load } \\
(\mathrm{kg})\end{array}$ & $\begin{array}{l}\text { Flexural } \\
\text { strength } \\
(M P a)\end{array}$ & $\begin{array}{l}\text { Normalized } \\
\text { strength }\end{array}$ & $\begin{array}{l}\text { Average } \\
\text { normalized } \\
\text { strength }\end{array}$ & $\begin{array}{l}\text { Standard } \\
\text { Deviation }\end{array}$ \\
\hline $102 a$ & 1 & -10 & 860 & 1.64 & 0.5 & 63.2 & 4.83 & 3.1 & & \\
\hline $102 b$ & 1 & -10 & 860 & 1.73 & 0.6 & 64.6 & 4.45 & 2.9 & & \\
\hline $87 a$ & 1 & -10 & 860 & 1.71 & 0.5 & 75.3 & 5.26 & 3.4 & & \\
\hline $87 \mathrm{~b}$ & 1 & -10 & 860 & 1.60 & 0.6 & 35.7 & 2.86 & 1.9 & & \\
\hline $90 a$ & 1 & -10 & 840 & 1.70 & 0.7 & 65.8 & 4.67 & 3.0 & & \\
\hline $90 \mathrm{~b}$ & 1 & -10 & 840 & 1.58 & 0.9 & 43.9 & 3.63 & 2.4 & & \\
\hline $93 a$ & 1 & -10 & 850 & 1.63 & 0.3 & 50.7 & 3.93 & 2.6 & & \\
\hline $93 b$ & 1 & -10 & 850 & 1.55 & 0.4 & 43.7 & 3.73 & 2.4 & 2.7 & 0.5 \\
\hline $86 a$ & 1 & -15 & 840 & 1.70 & 0.5 & 54.0 & 3.83 & 2.5 & & \\
\hline $86 b$ & 1 & -15 & 840 & 1.65 & 0.3 & 46.8 & 3.52 & 2.3 & & \\
\hline $89 a$ & 1 & -15 & 850 & 1.70 & 0.5 & 59.8 & 4.24 & 2.8 & & \\
\hline $89 b$ & 1 & -15 & 850 & 1.70 & 0.6 & 58.6 & 4.16 & 2.7 & & \\
\hline $92 a$ & 1 & -15 & 840 & 1.76 & 0.4 & 54.8 & 3.61 & 2.3 & & \\
\hline $92 b$ & 1 & -15 & 840 & 1.68 & 0.5 & 59.1 & 4.32 & 2.8 & & \\
\hline $98 a$ & 1 & -15 & 850 & 1.70 & 0.4 & 67.5 & 4.79 & 3.1 & & \\
\hline $98 b$ & 1 & -15 & 850 & 1.66 & 0.4 & 55.2 & 4.10 & 2.7 & 2.6 & 0.3 \\
\hline $100 a$ & 1 & -25 & 880 & 1.60 & 0.4 & 59.6 & 4.77 & 3.1 & & \\
\hline $85 a$ & 1 & -25 & 840 & 1.53 & 0.3 & 43.4 & 3.83 & 2.5 & & \\
\hline $85 b$ & 1 & -25 & 840 & 1.64 & 0.6 & 60.1 & 4.59 & 3.0 & & \\
\hline $88 a$ & 1 & -25 & 850 & 1.58 & 0.5 & 42.2 & 3.49 & 2.3 & & \\
\hline $88 b$ & 1 & -25 & 850 & 1.65 & 0.3 & 57.7 & 4.34 & 2.8 & & \\
\hline $88 c$ & 1 & -25 & 850 & 1.43 & 0.4 & 32.1 & 3.24 & 2.1 & & \\
\hline $97 a$ & 1 & -25 & 880 & 1.66 & 0.3 & 56.4 & 4.19 & 2.7 & & \\
\hline $97 \mathrm{~b}$ & 1 & -25 & 880 & 1.54 & 0.3 & 40.0 & 3.47 & 2.3 & 2.6 & 0.4 \\
\hline $69 a$ & 5 & -10 & 860 & 1.65 & 0.4 & 61.3 & 4.61 & 3.0 & & \\
\hline $69 \mathrm{~b}$ & 5 & -10 & 860 & 1.53 & 0.4 & 42.7 & 3.76 & 2.4 & & \\
\hline $72 a$ & 5 & -10 & 880 & 1.60 & 0.3 & 51.4 & 4.11 & 2.7 & & \\
\hline $72 b$ & 5 & -10 & 880 & 1.59 & 0.4 & 58.4 & 4.75 & 3.1 & & \\
\hline $75 a$ & 5 & -10 & 870 & 1.50 & 0.4 & 54.0 & 4.92 & 3.2 & & \\
\hline $75 b$ & 5 & -10 & 870 & 1.70 & 0.5 & 70.9 & 5.03 & 3.3 & & \\
\hline $84 a$ & 5 & -10 & 890 & 1.66 & 0.4 & 62.0 & 4.60 & 3.0 & & \\
\hline $84 b$ & 5 & -10 & 890 & 1.66 & 0.5 & 75.5 & 5.60 & 3.6 & 3.0 & 0.4 \\
\hline $68 a$ & 5 & -15 & 850 & 1.63 & 0.4 & 77.9 & 6.05 & 3.9 & & \\
\hline $68 b$ & 5 & -15 & 850 & 1.70 & 0.5 & 62.2 & 4.41 & 2.9 & & \\
\hline $71 a$ & 5 & -15 & 850 & 1.70 & 0.4 & 34.0 & 2.41 & 1.6 & & \\
\hline $71 \mathrm{~b}$ & 5 & -15 & 850 & 1.73 & 0.7 & 1.2 & 0.08 & 0.1 & & \\
\hline $77 a$ & 5 & -15 & 860 & 1.70 & 0.5 & 71.2 & 5.05 & 3.3 & & \\
\hline $77 \mathrm{~b}$ & 5 & -15 & 860 & 1.79 & 0.4 & 74.6 & 4.78 & 3.1 & & \\
\hline $80 a$ & 5 & -15 & 870 & 1.69 & 0.5 & 58.9 & 4.24 & 2.8 & & \\
\hline $80 \mathrm{~b}$ & 5 & -15 & 870 & 1.61 & 0.4 & 62.0 & 4.89 & 3.2 & 2.6 & 1.2 \\
\hline $67 a$ & 5 & -25 & 870 & 1.70 & 0.6 & 71.6 & 5.08 & 3.3 & & \\
\hline $73 a$ & 5 & -25 & 850 & 1.73 & 0.4 & 53.3 & 3.67 & 2.4 & & \\
\hline $73 b$ & 5 & -25 & 850 & 1.61 & 0.3 & 46.6 & 3.67 & 2.4 & & \\
\hline $76 a$ & 5 & -25 & 860 & 1.53 & 0.5 & 53.8 & 4.74 & 3.1 & & \\
\hline $76 b$ & 5 & -25 & 860 & 1.68 & 0.5 & 74.3 & 5.43 & 3.5 & & \\
\hline $79 a$ & 5 & -25 & 890 & 1.68 & 0.8 & 76.9 & 5.62 & 3.7 & & \\
\hline $79 \mathrm{~b}$ & 5 & -25 & 890 & 1.59 & 0.6 & 65.4 & 5.32 & 3.5 & 3.1 & 0.5 \\
\hline $48 a$ & 10 & -10 & 810 & 1.53 & 0.4 & 35.0 & 3.08 & 2.0 & & \\
\hline $48 b$ & 10 & -10 & 810 & 1.71 & 0.4 & 58.1 & 4.06 & 2.6 & & \\
\hline $54 a$ & 10 & -10 & 820 & 1.56 & 0.4 & 55.0 & 4.62 & 3.0 & & \\
\hline $54 \mathrm{~b}$ & 10 & -10 & 820 & 1.73 & 0.5 & 57.7 & 3.97 & 2.6 & & \\
\hline $57 a$ & 10 & -10 & 840 & 1.70 & 0.4 & 58.6 & 4.16 & 2.7 & & \\
\hline $57 \mathrm{~b}$ & 10 & -10 & 840 & 1.68 & 0.4 & 55.7 & 4.07 & 2.6 & & \\
\hline $60 a$ & 10 & -10 & 820 & 1.63 & 0.4 & 61.3 & 4.76 & 3.1 & & \\
\hline $60 \mathrm{~b}$ & 10 & -10 & 820 & 1.68 & 0.5 & 46.6 & 3.40 & 2.2 & 2.6 & 0.4 \\
\hline
\end{tabular}




\begin{tabular}{|c|c|c|c|c|c|c|c|c|c|c|}
\hline $\begin{array}{l}\text { Sample } \\
\text { no. }\end{array}$ & $\begin{array}{l}\text { Storage } \\
\text { time } \\
\text { (days) }\end{array}$ & $\begin{array}{l}\text { Storage } \\
\text { temp } \\
\left({ }^{\circ} \mathrm{C}\right)\end{array}$ & $\begin{array}{l}\text { Density } \\
\left(\mathrm{kg} / \mathrm{m}^{3)}\right.\end{array}$ & $\begin{array}{l}\text { Disk } \\
\text { thickness } \\
(\mathrm{cm})\end{array}$ & $\begin{array}{l}\text { Maximum } \\
\text { deflection } \\
(\mathrm{mm})\end{array}$ & $\begin{array}{l}\text { Maximum } \\
\text { load } \\
(\mathrm{kg})\end{array}$ & $\begin{array}{l}\text { Flexural } \\
\text { strength } \\
(\mathrm{MPa})\end{array}$ & $\begin{array}{l}\text { Normalized } \\
\text { strength }\end{array}$ & $\begin{array}{l}\text { Average } \\
\text { normalized } \\
\text { strength }\end{array}$ & $\begin{array}{l}\text { Standard } \\
\text { Deviation }\end{array}$ \\
\hline $44 a$ & 10 & -15 & 830 & 1.70 & 0.5 & 55.7 & 3.95 & 2.6 & & \\
\hline $44 b$ & 10 & -15 & 830 & 1.58 & 0.3 & 49.4 & 4.09 & 2.7 & & \\
\hline $47 a$ & 10 & -15 & 800 & 1.70 & 0.8 & 60.5 & 4.30 & 2.8 & & \\
\hline $47 \mathrm{~b}$ & 10 & -15 & 800 & 1.70 & 0.5 & 54.3 & 3.85 & 2.5 & & \\
\hline $53 a$ & 10 & -15 & 820 & 1.70 & 0.6 & 68.3 & 4.84 & 3.1 & & \\
\hline $53 b$ & 10 & -15 & 820 & 1.65 & 0.6 & 63.2 & 4.76 & 3.1 & & \\
\hline $56 a$ & 10 & -15 & 830 & 1.75 & 0.6 & 54.0 & 3.62 & 2.4 & & \\
\hline $56 \mathrm{~b}$ & 10 & -15 & 830 & 1.63 & 0.3 & 49.4 & 3.84 & 2.5 & 2.7 & 0.3 \\
\hline $26 a$ & 20 & -10 & 820 & 1.58 & 0.5 & 54.0 & 4.47 & 2.9 & & \\
\hline $26 \mathrm{~b}$ & 20 & -10 & 820 & 1.70 & 0.5 & 63.2 & 4.48 & 2.9 & & \\
\hline $27 a$ & 20 & -10 & 840 & 1.55 & 0.4 & 44.1 & 3.77 & 2.4 & & \\
\hline $27 \mathrm{~b}$ & 20 & -10 & 840 & 1.66 & 0.3 & 61.3 & 4.54 & 3.0 & & \\
\hline $28 a$ & 20 & -10 & 880 & 1.71 & 0.3 & 54.5 & 3.81 & 2.5 & & \\
\hline $28 b$ & 20 & -10 & 880 & 1.56 & 0.4 & 51.6 & 4.34 & 2.8 & & \\
\hline $29 a$ & 20 & -10 & 850 & 1.64 & 0.6 & 66.1 & 5.05 & 3.3 & & \\
\hline $29 b$ & 20 & -10 & 850 & 1.56 & 0.4 & 56.9 & 4.78 & 3.1 & 2.9 & 0.3 \\
\hline $20 a$ & 20 & -15 & 830 & 1.69 & 0.3 & 71.4 & 5.14 & 3.3 & & \\
\hline $20 b$ & 20 & -15 & 830 & 1.65 & 0.6 & 69.5 & 5.23 & 3.4 & & \\
\hline $21 a$ & 20 & -15 & 830 & 1.58 & 0.4 & 54.0 & 4.47 & 2.9 & & \\
\hline $21 b$ & 20 & -15 & 830 & 1.69 & 0.5 & 73.5 & 5.29 & 3.4 & & \\
\hline $22 a$ & 20 & -15 & 820 & 1.68 & 0.5 & 60.3 & 4.41 & 2.9 & & \\
\hline $22 b$ & 20 & -15 & 820 & 1.70 & 0.5 & 70.9 & 5.03 & 3.3 & & \\
\hline $23 a$ & 20 & -15 & 840 & 1.60 & 0.5 & 68.5 & 5.49 & 3.6 & & \\
\hline $23 b$ & 20 & -15 & 840 & 1.73 & 0.4 & 57.9 & 3.99 & 2.6 & 3.2 & 0.3 \\
\hline $13 a$ & 20 & -25 & 830 & 1.60 & 0.4 & 56.2 & 4.50 & 2.9 & & \\
\hline $13 b$ & 20 & -25 & 830 & 1.60 & 0.4 & 45.1 & 3.61 & 2.3 & & \\
\hline $15 a$ & 20 & -25 & 810 & 1.64 & 0.4 & 42.7 & 3.26 & 2.1 & & \\
\hline $15 b$ & 20 & -25 & 810 & 1.69 & 0.4 & 65.1 & 4.69 & 3.0 & & \\
\hline $17 a$ & 20 & -25 & 820 & 1.64 & 0.5 & 65.4 & 5.00 & 3.2 & & \\
\hline $18 a$ & 20 & -25 & 840 & 1.56 & 0.5 & 55.5 & 4.66 & 3.0 & & \\
\hline $18 b$ & 20 & -25 & 840 & 1.68 & 0.5 & 47.3 & 3.45 & 2.2 & 2.7 & 0.5 \\
\hline ClrBub1 & $\mathrm{N} / \mathrm{A}$ & ambient & 880 & 1.60 & 0.3 & 55.2 & 4.42 & 2.9 & & \\
\hline ClrBub2 & $N / A$ & ambient & 880 & 1.55 & 0.3 & 34.0 & 2.90 & 1.9 & & \\
\hline DiscBub1 & N/A & ambient & 880 & 1.54 & 0.2 & 27.7 & 2.41 & 1.6 & & \\
\hline DiscBub2 & $\mathrm{N} / \mathrm{A}$ & ambient & 880 & 2.08 & 0.4 & 78.6 & 3.74 & 2.4 & & \\
\hline DiscBub3 & $\mathrm{N} / \mathrm{A}$ & ambient & 880 & 2.38 & 0.5 & 62.0 & 2.25 & 1.5 & 2.0 & 0.6 \\
\hline Sup1 & $\mathrm{N} / \mathrm{A}$ & ambient & 920 & 1.45 & 0.2 & 21.7 & 2.12 & 1.4 & & \\
\hline Sup2 & N/A & ambient & 920 & 1.58 & 0.2 & 30.4 & 2.51 & 1.6 & & \\
\hline Sup3 & $\mathrm{N} / \mathrm{A}$ & ambient & 920 & 1.55 & 0.1 & 20.3 & 1.73 & 1.1 & & \\
\hline Sup4 & N/A & ambient & 920 & 1.51 & 0.1 & 25.1 & 2.25 & 1.5 & & \\
\hline Sup5 & $\mathrm{N} / \mathrm{A}$ & ambient & 920 & 1.73 & 0.2 & 24.6 & 1.70 & 1.1 & 1.3 & 0.2 \\
\hline
\end{tabular}

ClrBub

DiscBub

Clear, bubbly snow ice

Sup

Discolored, bubbly snow ice

Clear lake ice 
APPENDIX D: THIN SECTIONS OF REPRESENTATIVE SAMPLES OF CFG ICE

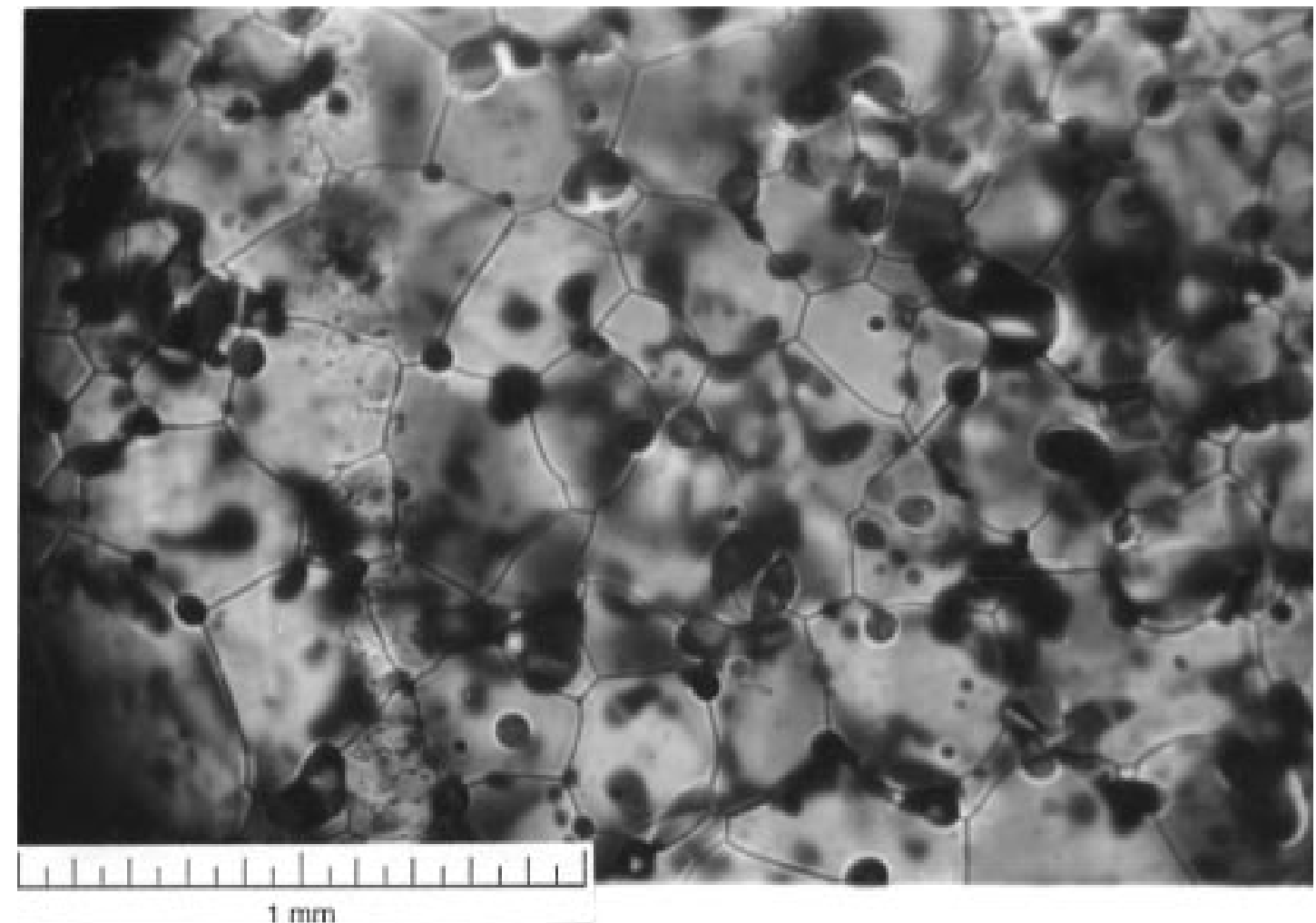

Figure D1. Sample stored 1 day at $-10^{\circ}$ (horizontal section)

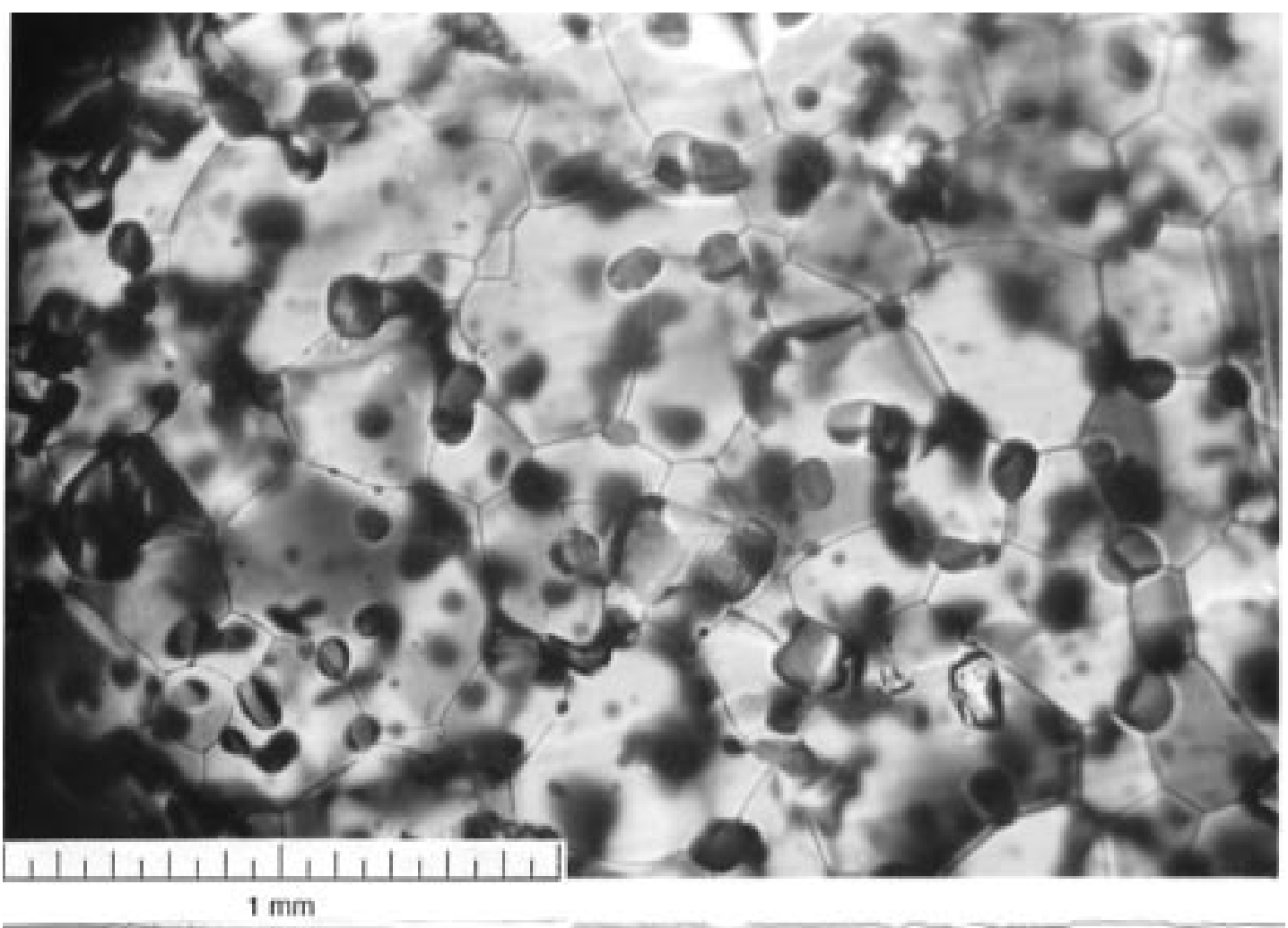

Figure D2. Sample stored 1 day at $-10^{\circ}$ (vertical section). 


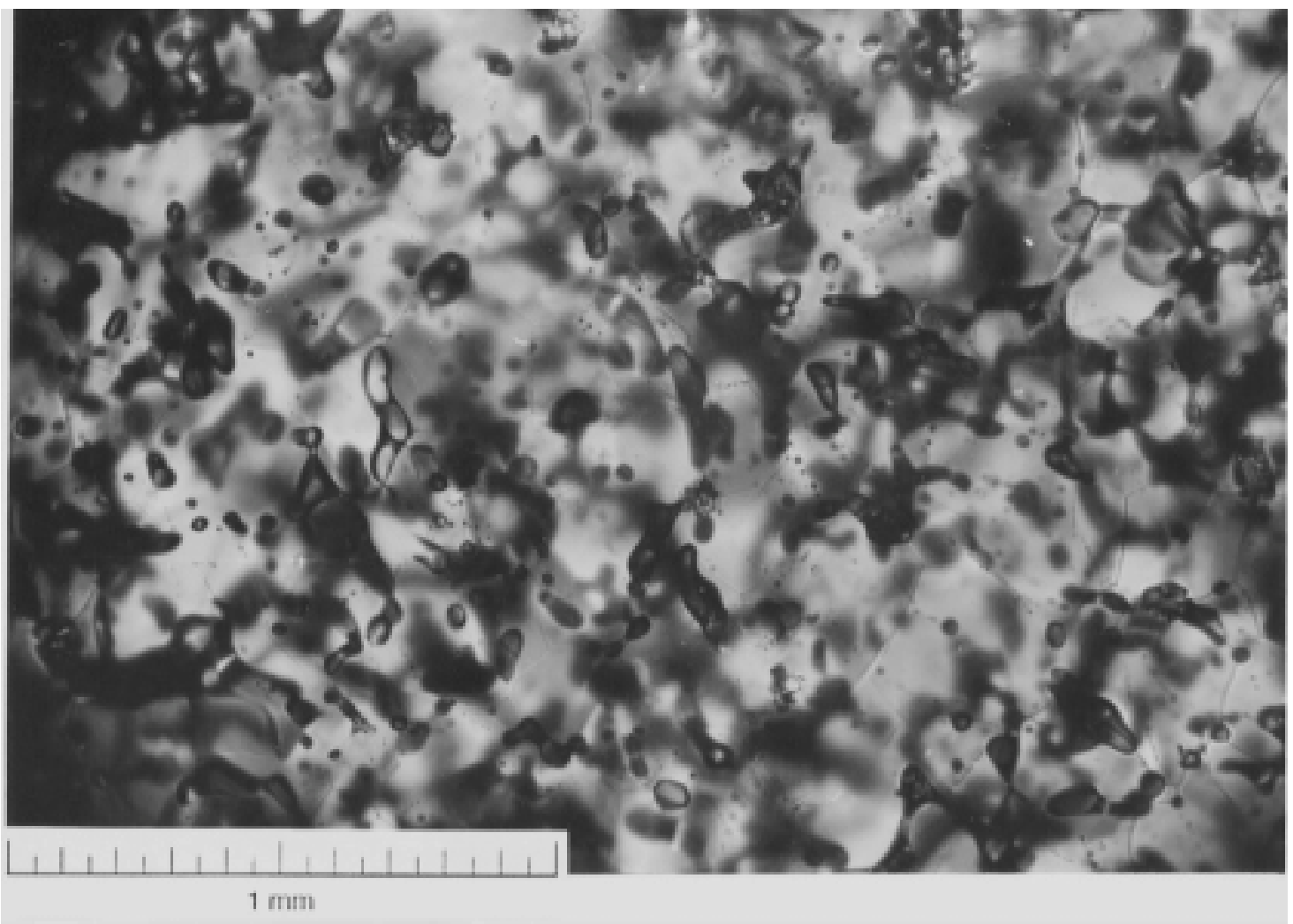

Figure D3. Sample stored 1 day at $-15^{\circ}$ (horizontal section).

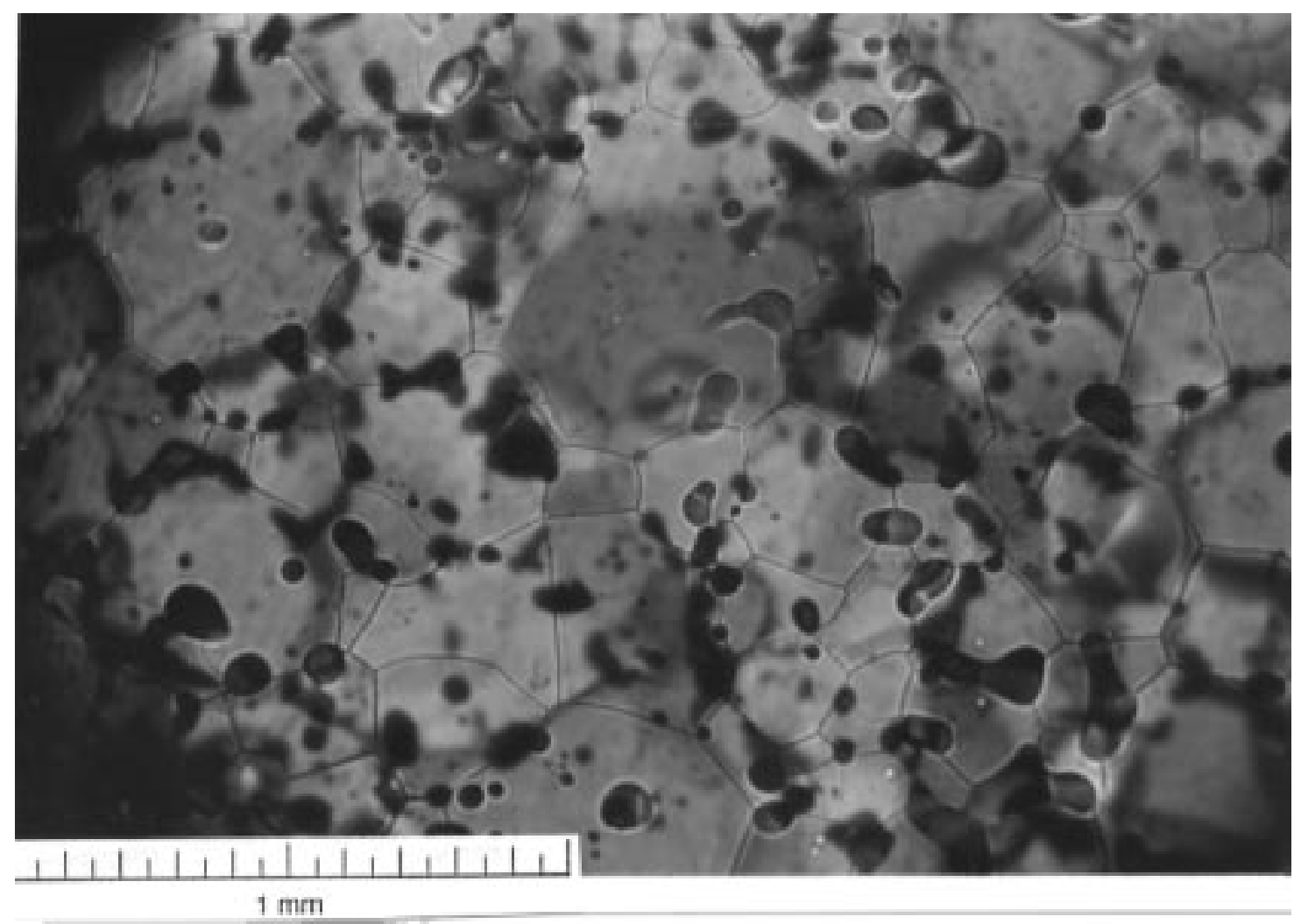

Figure D4. Sample stored 1 day at $-15^{\circ}$ (vertical section). 


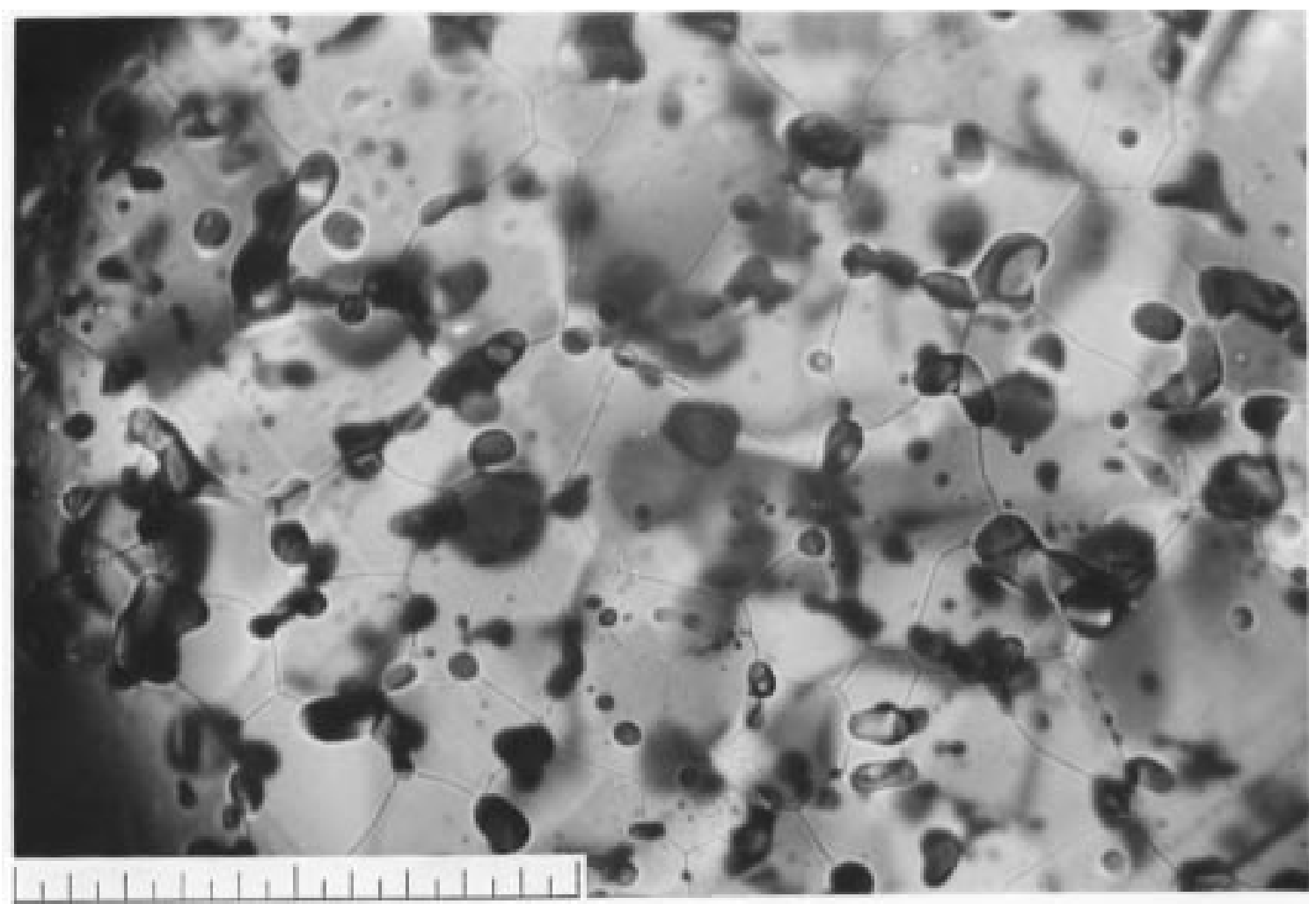

$1 \mathrm{~mm}$

Figure D5. Sample stored 1 day at $-2^{\circ}$ (horizontal section).

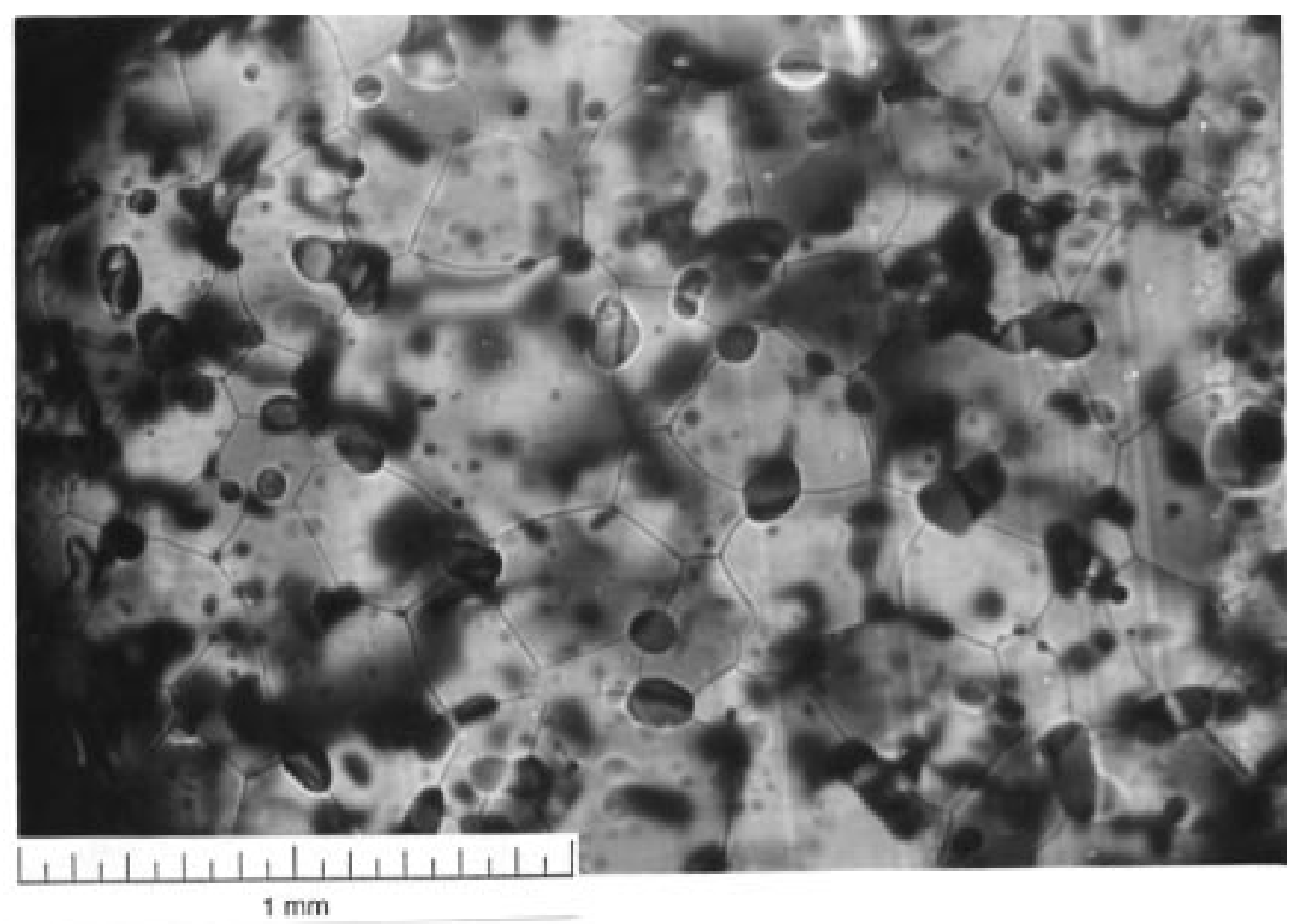

Figure D6. Sample stored 1 day at $-25^{\circ}$ (vertical section). 


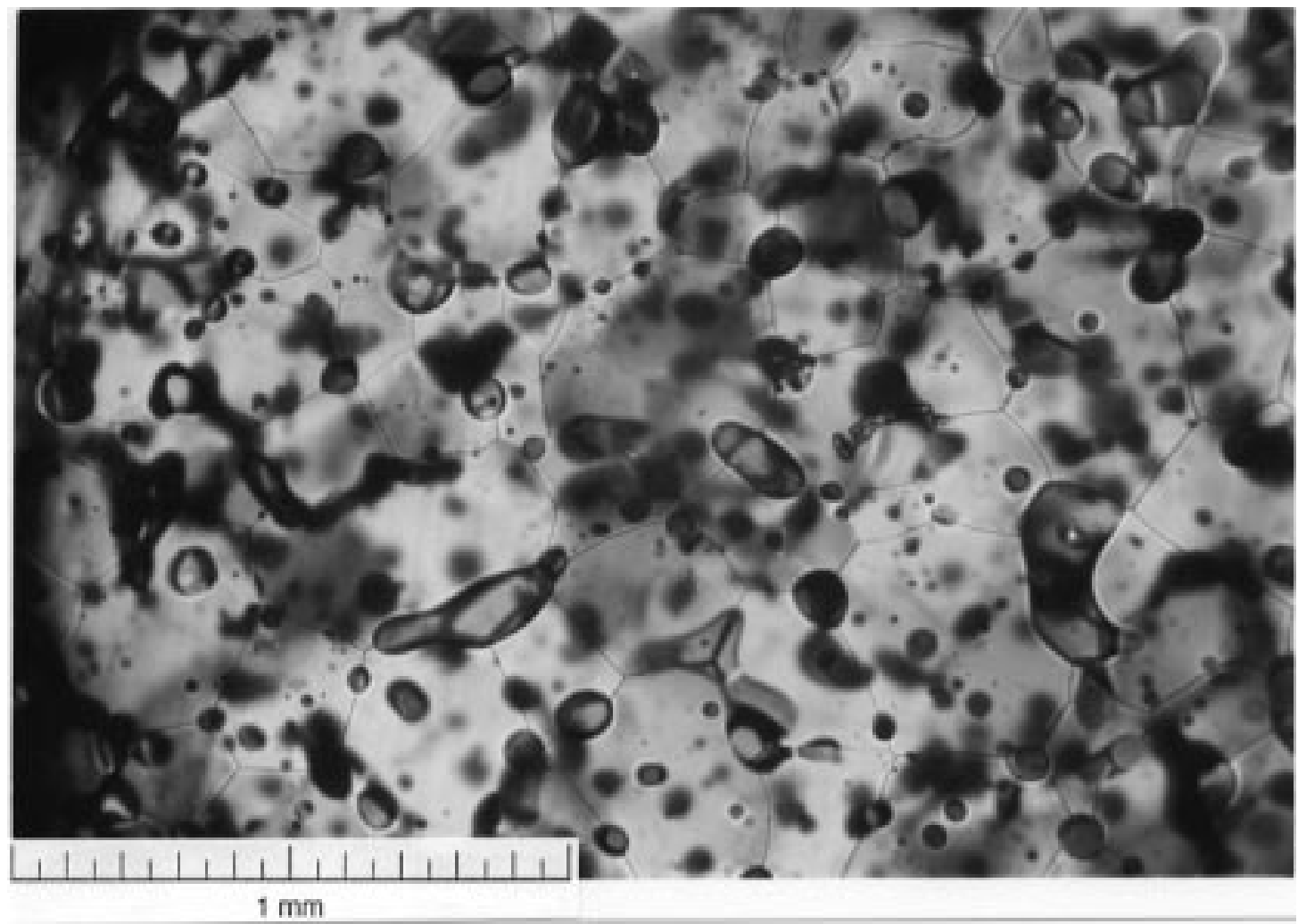

Figure D7. Sample stored 5 days at $-10^{\circ}$ (horizontal section).

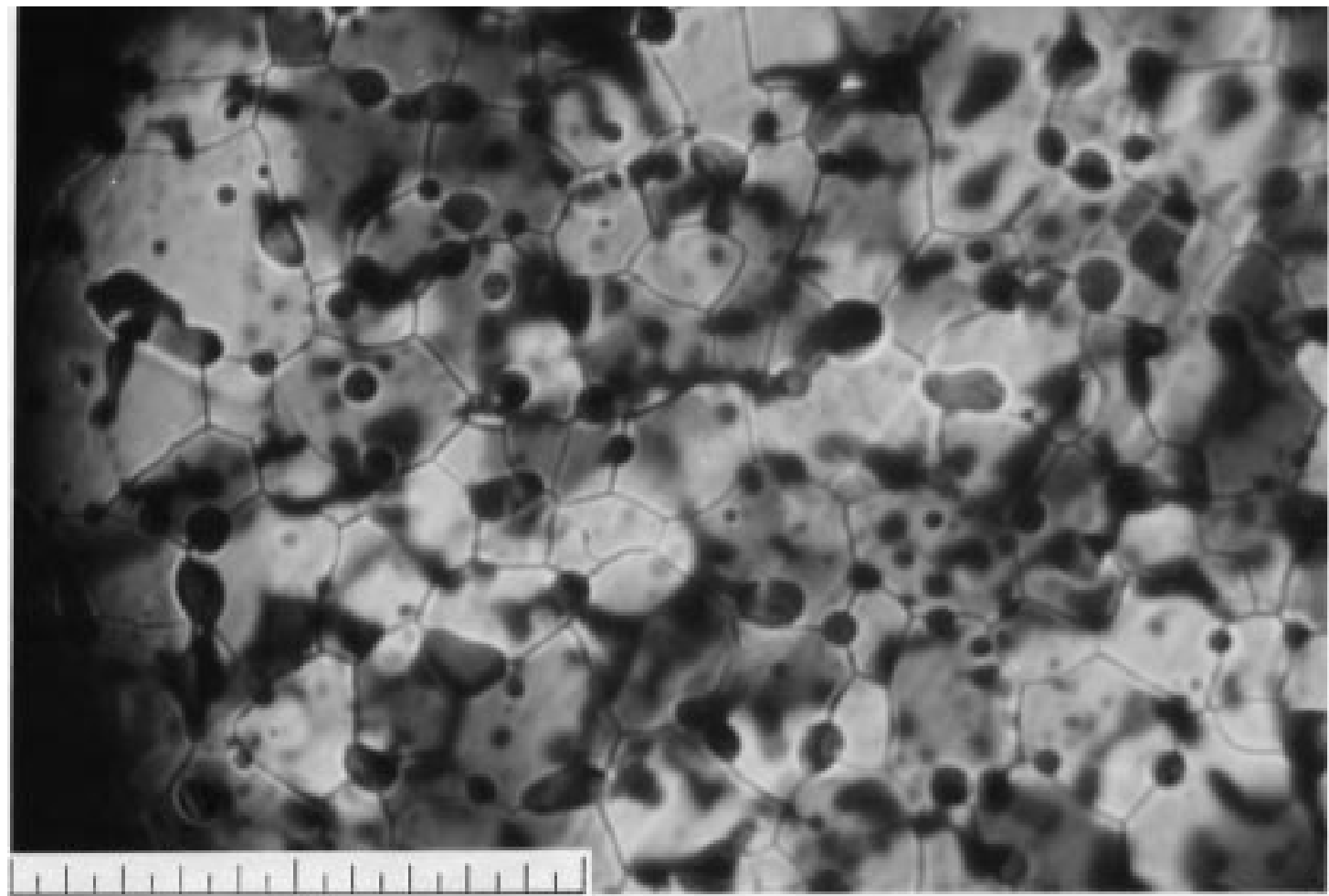

$1 \mathrm{~mm}$

Figure D8. Sample stored 5 days at $-15^{\circ}$ (vertical section). 


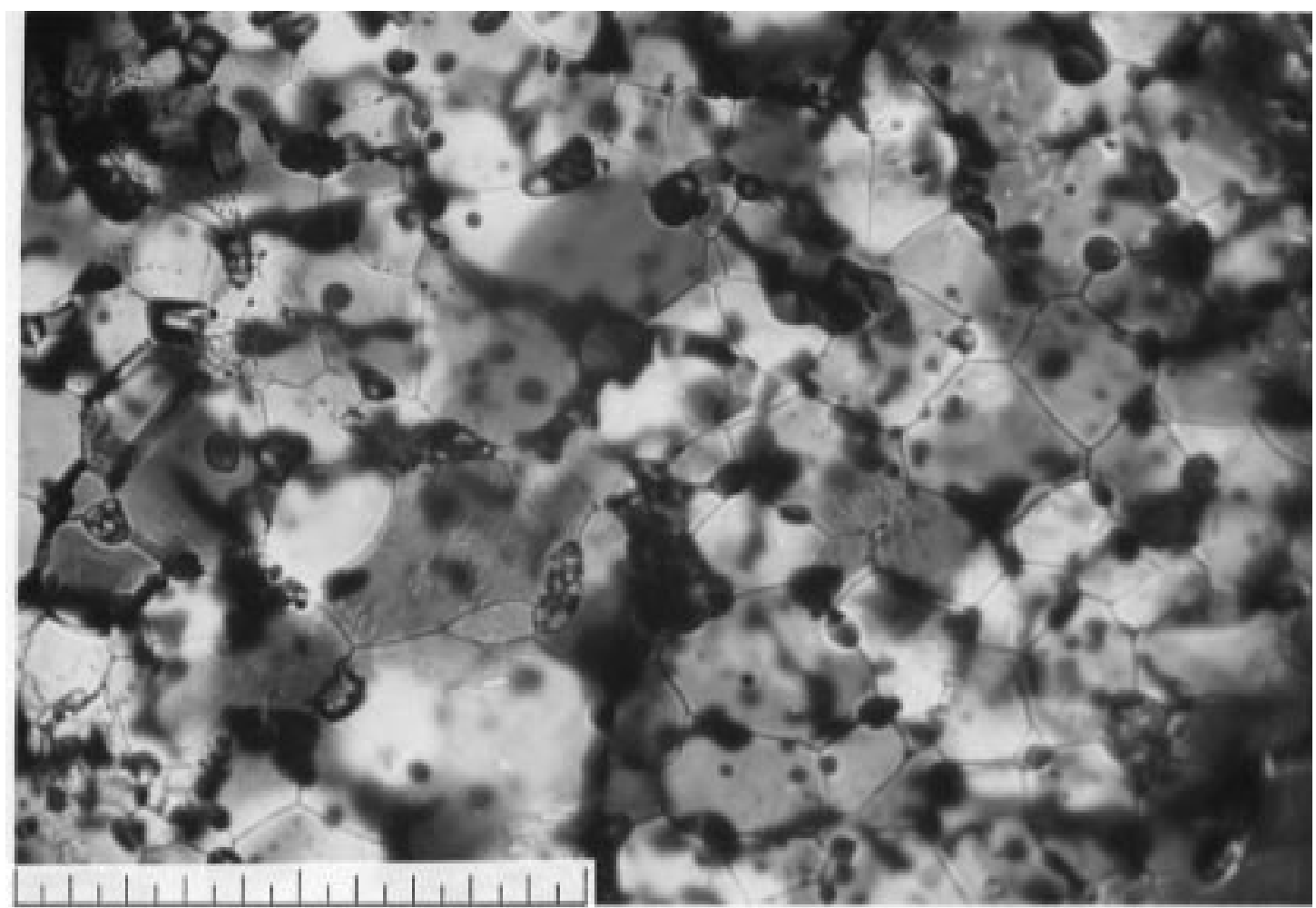

1 mm

Figure D9. Sample stored 5 days at $-2^{\circ}$ (horizontal section).

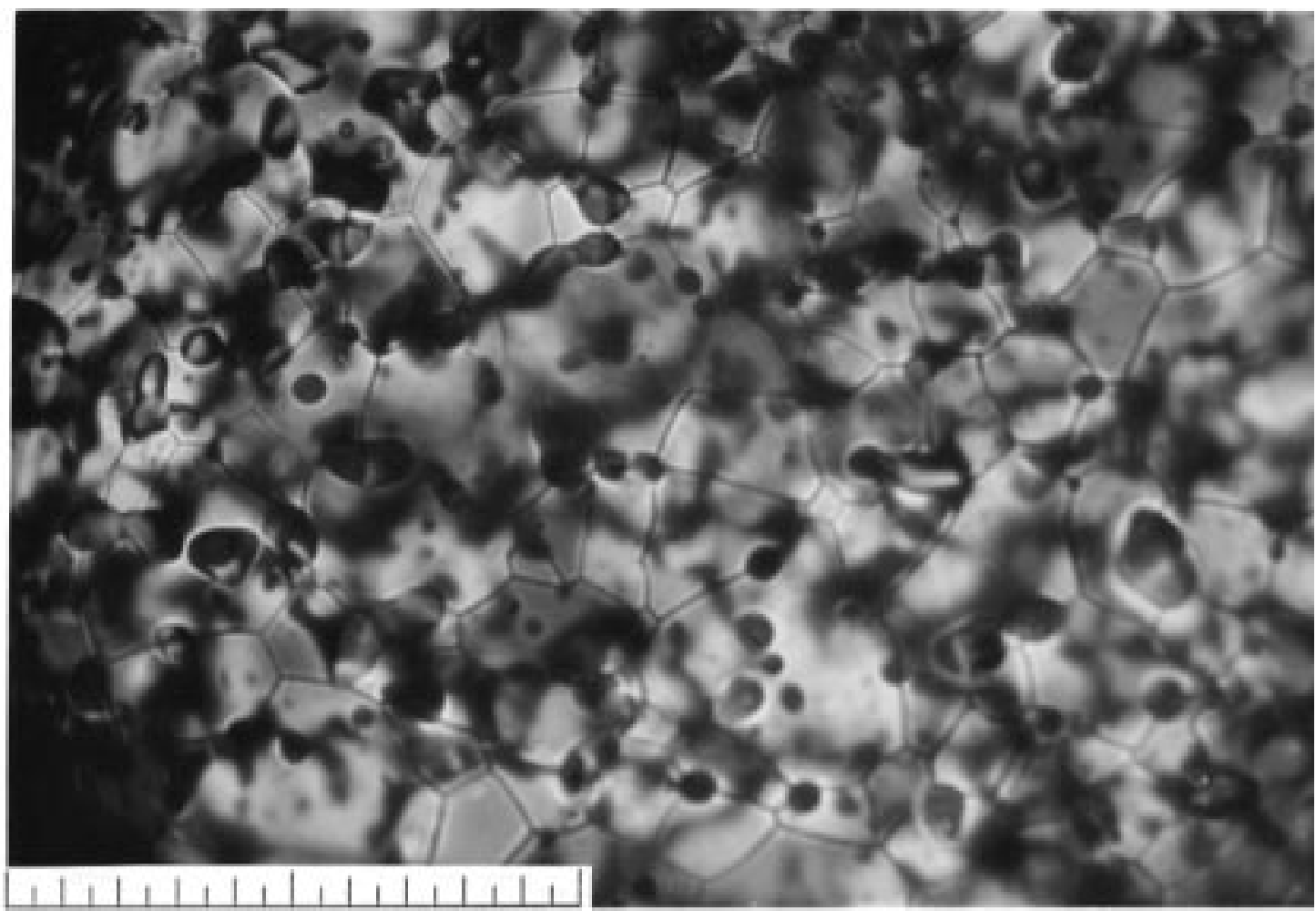

$1 \mathrm{~mm}$

Figure D10. Sample stored 5 days at $-25^{\circ}$ (vertical section). 


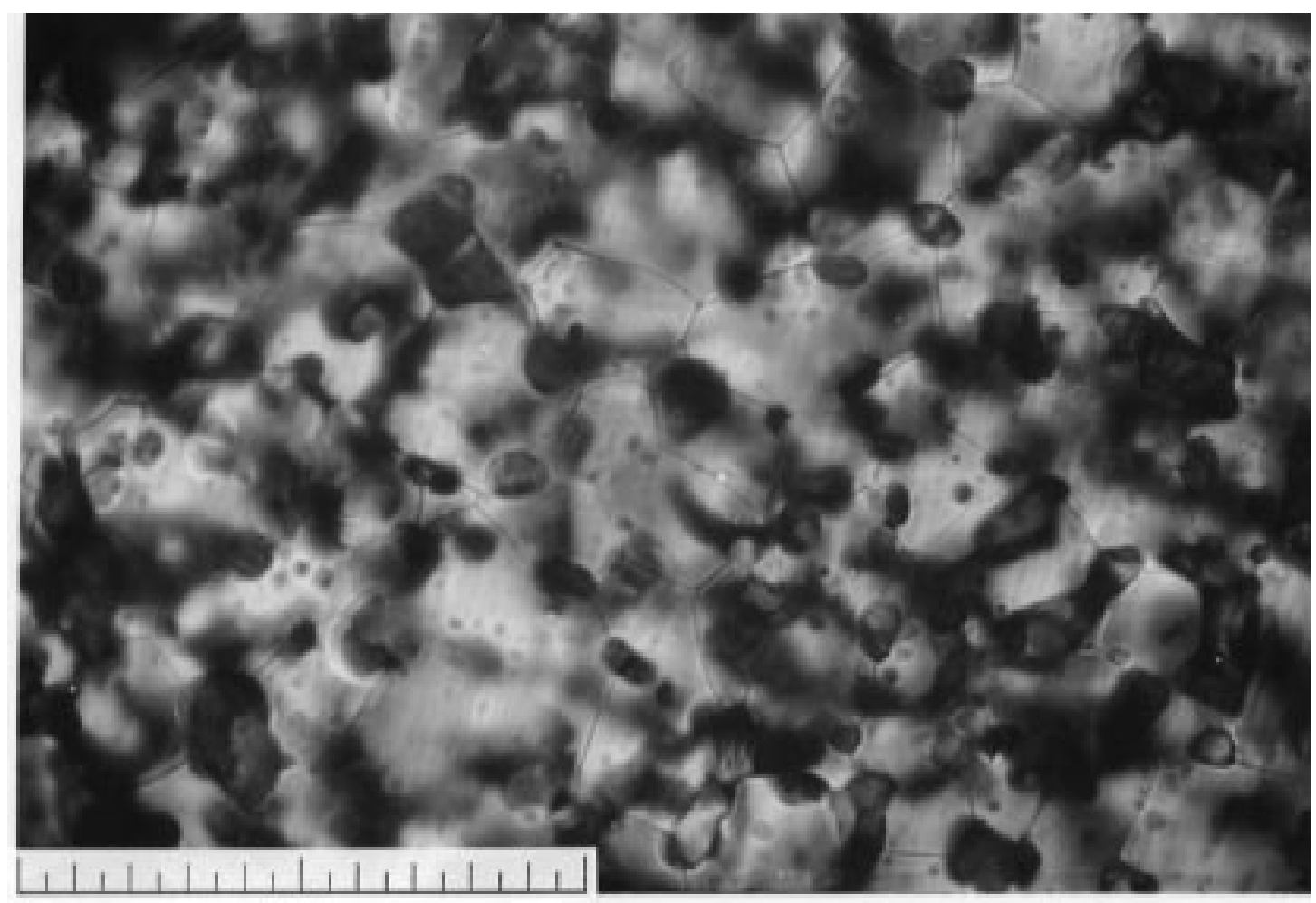

$1 \mathrm{~mm}$

Figure D11. Sample stored 10 days at $-15^{\circ}$ (horizontal section).

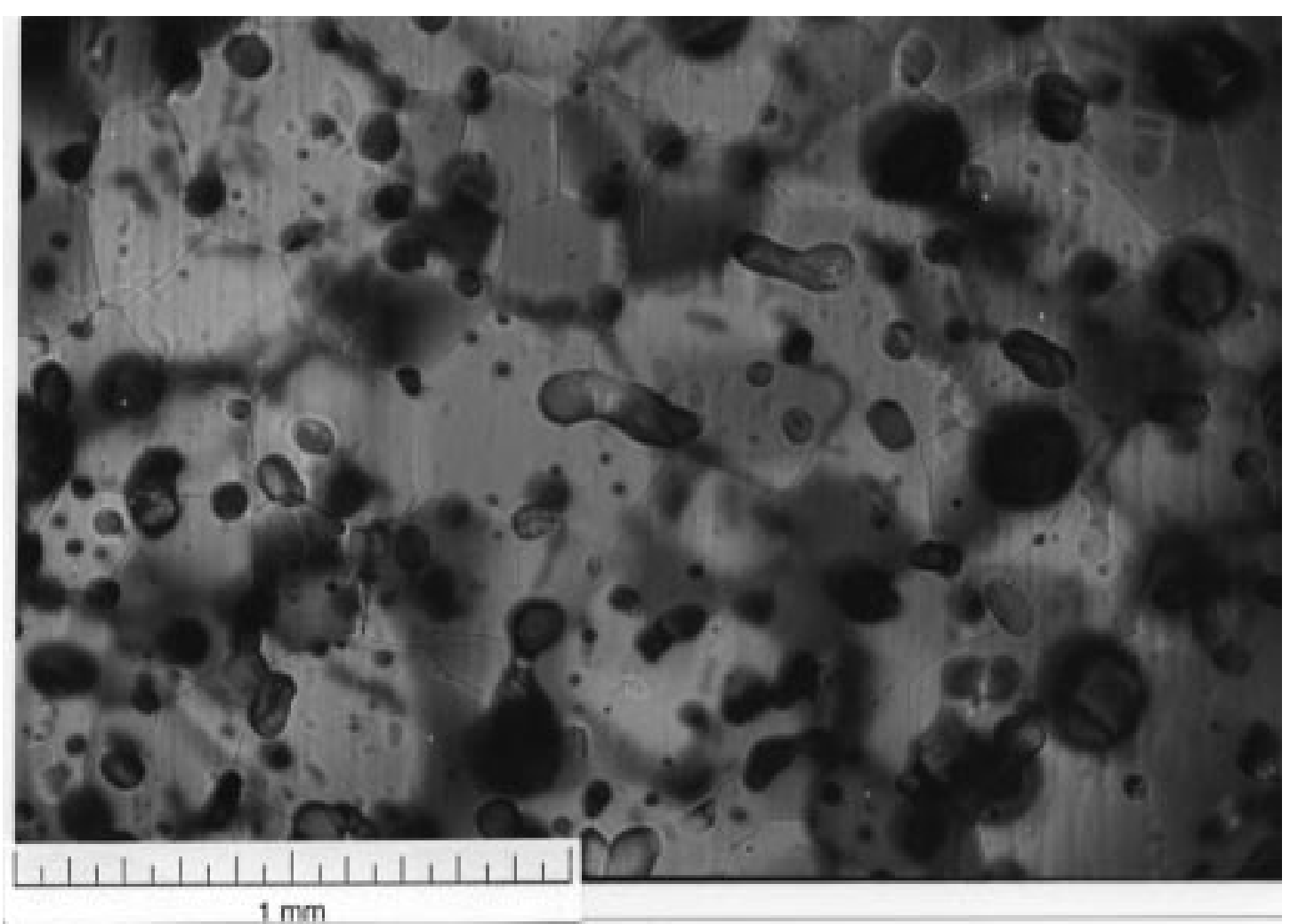

Figure D12. Sample stored 10 days at $-15^{\circ}$ (vertical section). 


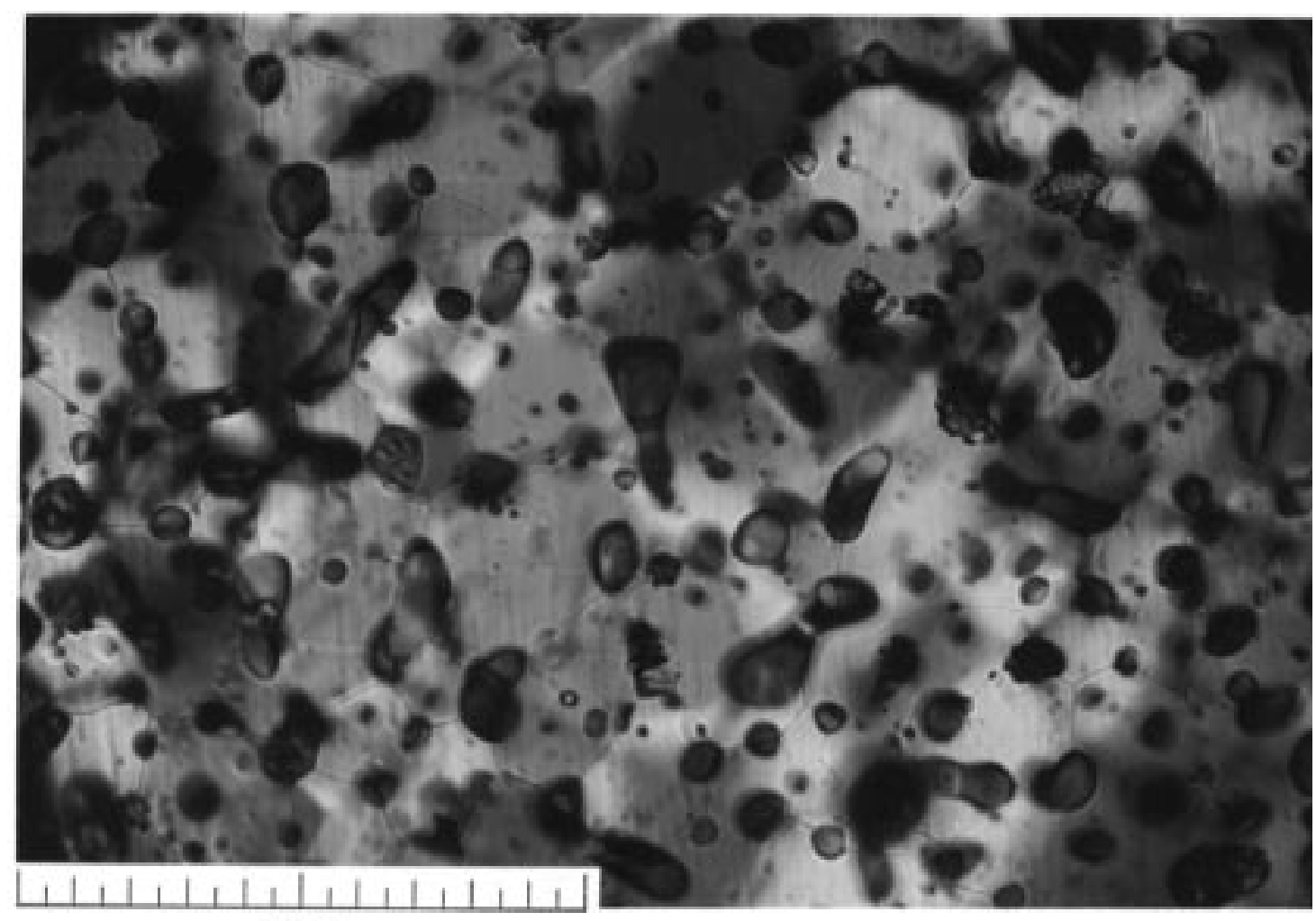

$1 \mathrm{~mm}$

Figure D13. Sample stored 20 days at $-10^{\circ}$ (horizontal section).

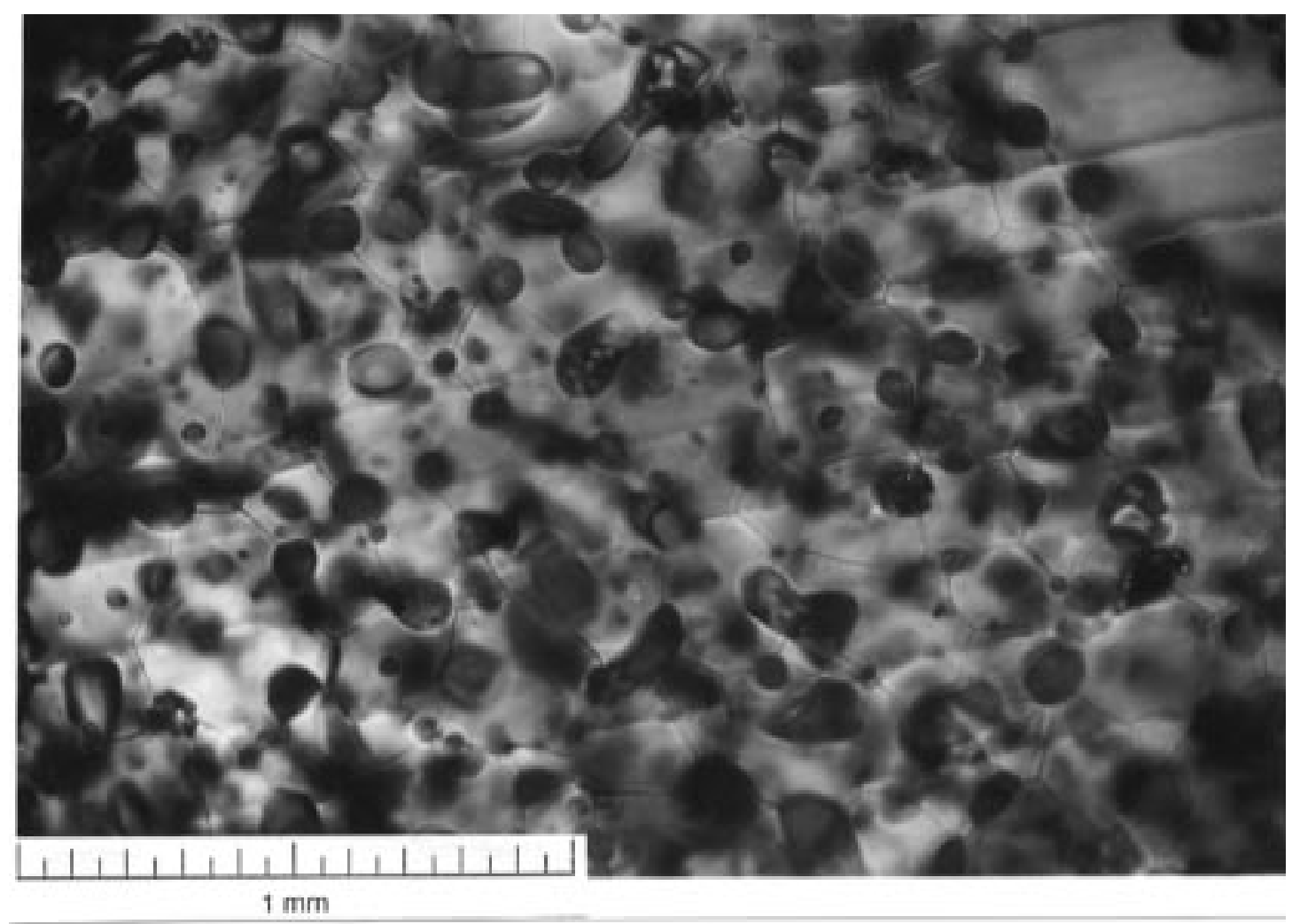

Figure D14. Sample stored 20 days at $-10^{\circ}$ (vertical section). 


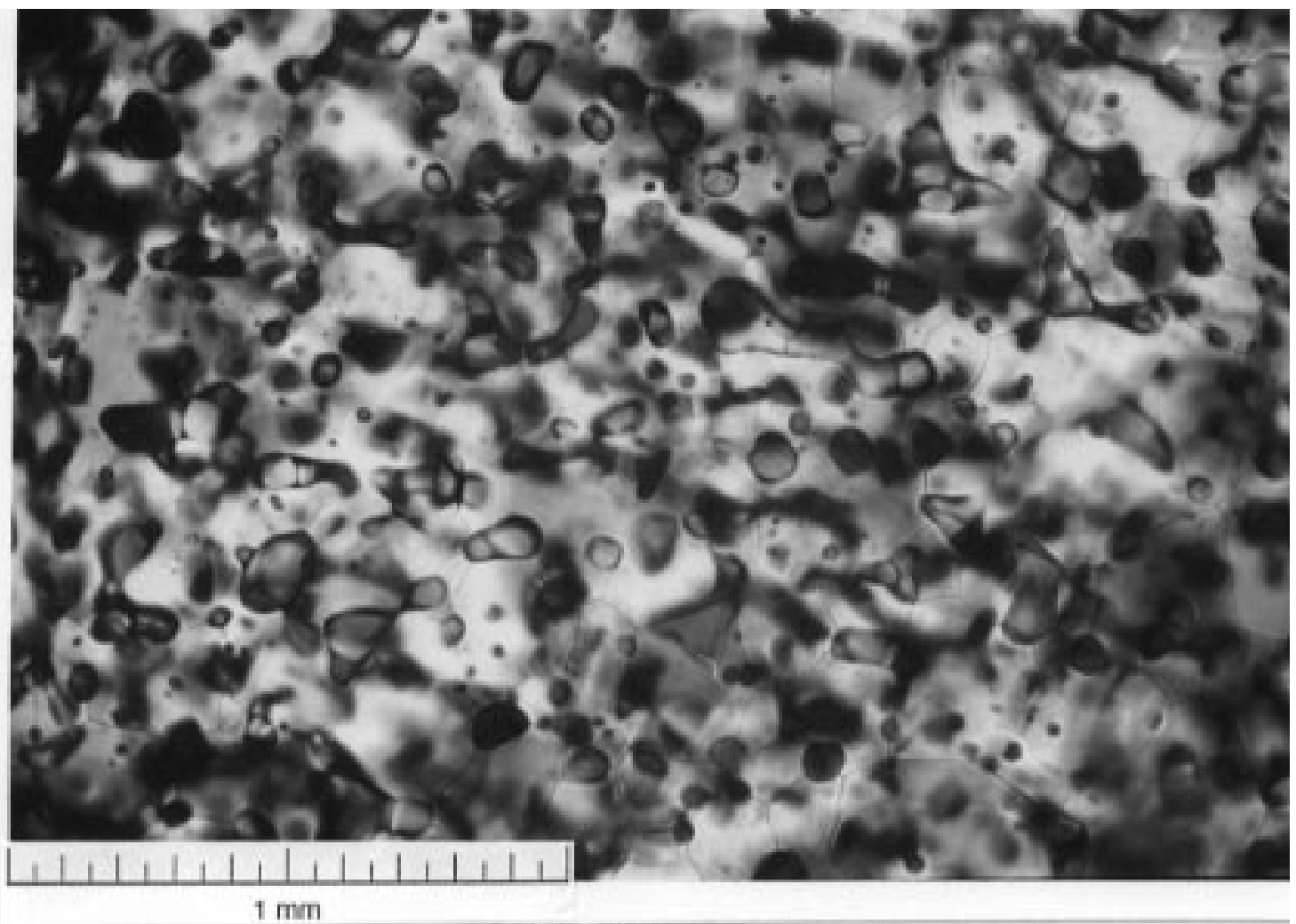

Figure D15. Sample stored 20 days at $-25^{\circ}$ (vertical section).

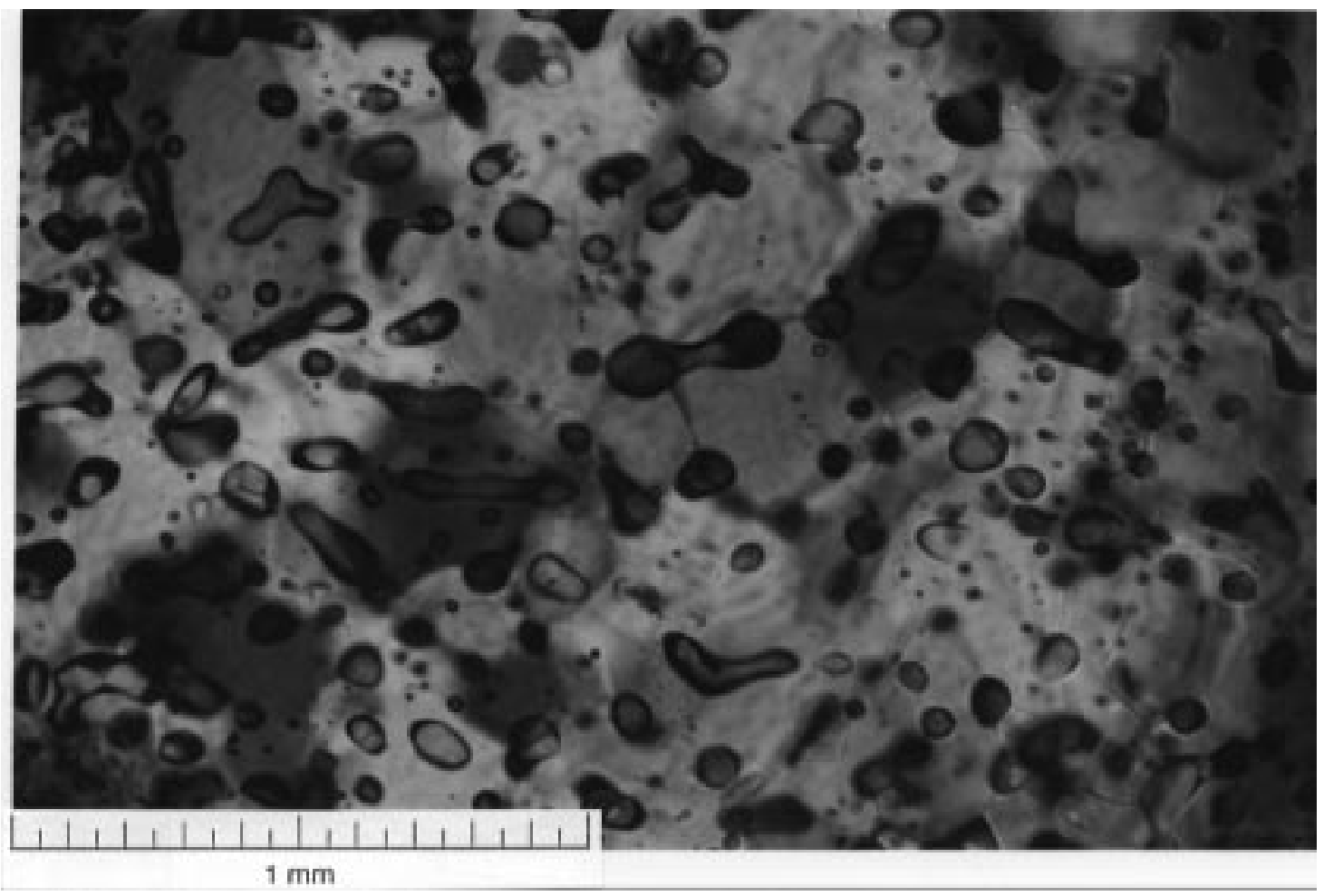

Figure D16. Sample stored 20 days at $-15^{\circ}$ (vertical section). 


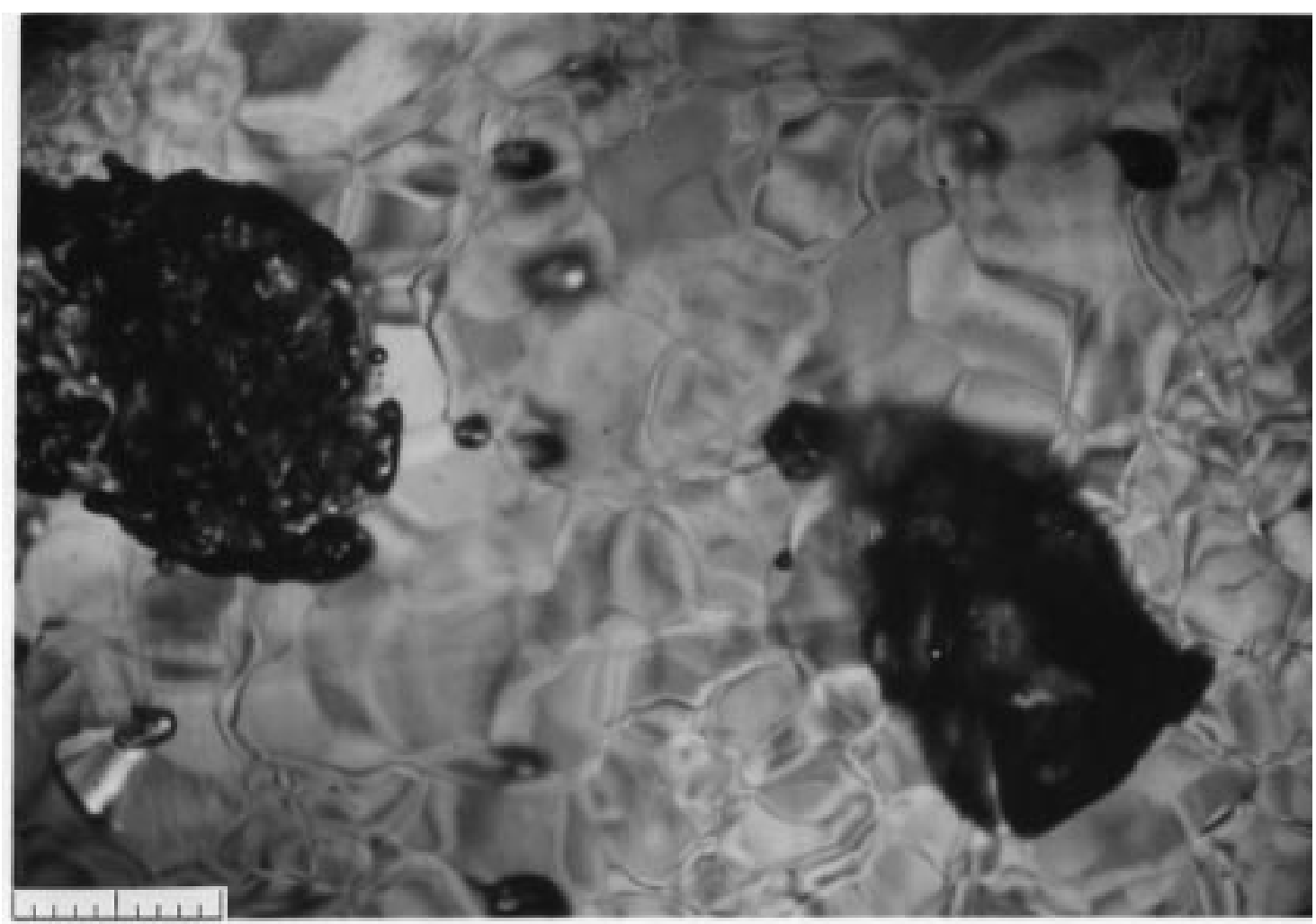

$1 \mathrm{~mm}$

Figure D17. Natural snow ice with bubbles.

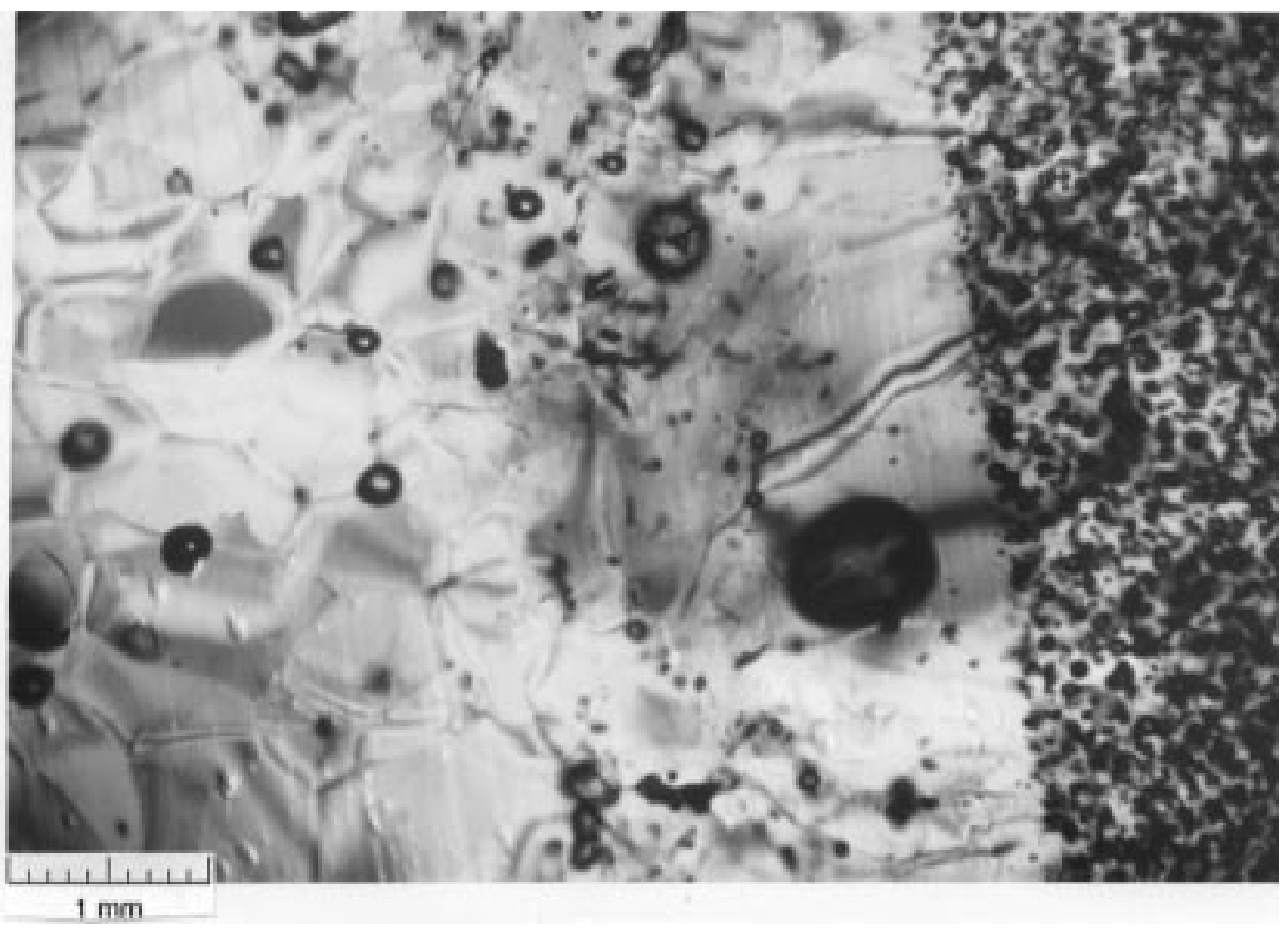

Figure D18. Natural snow ice (left) surrounding embedded CFG ice (right). 


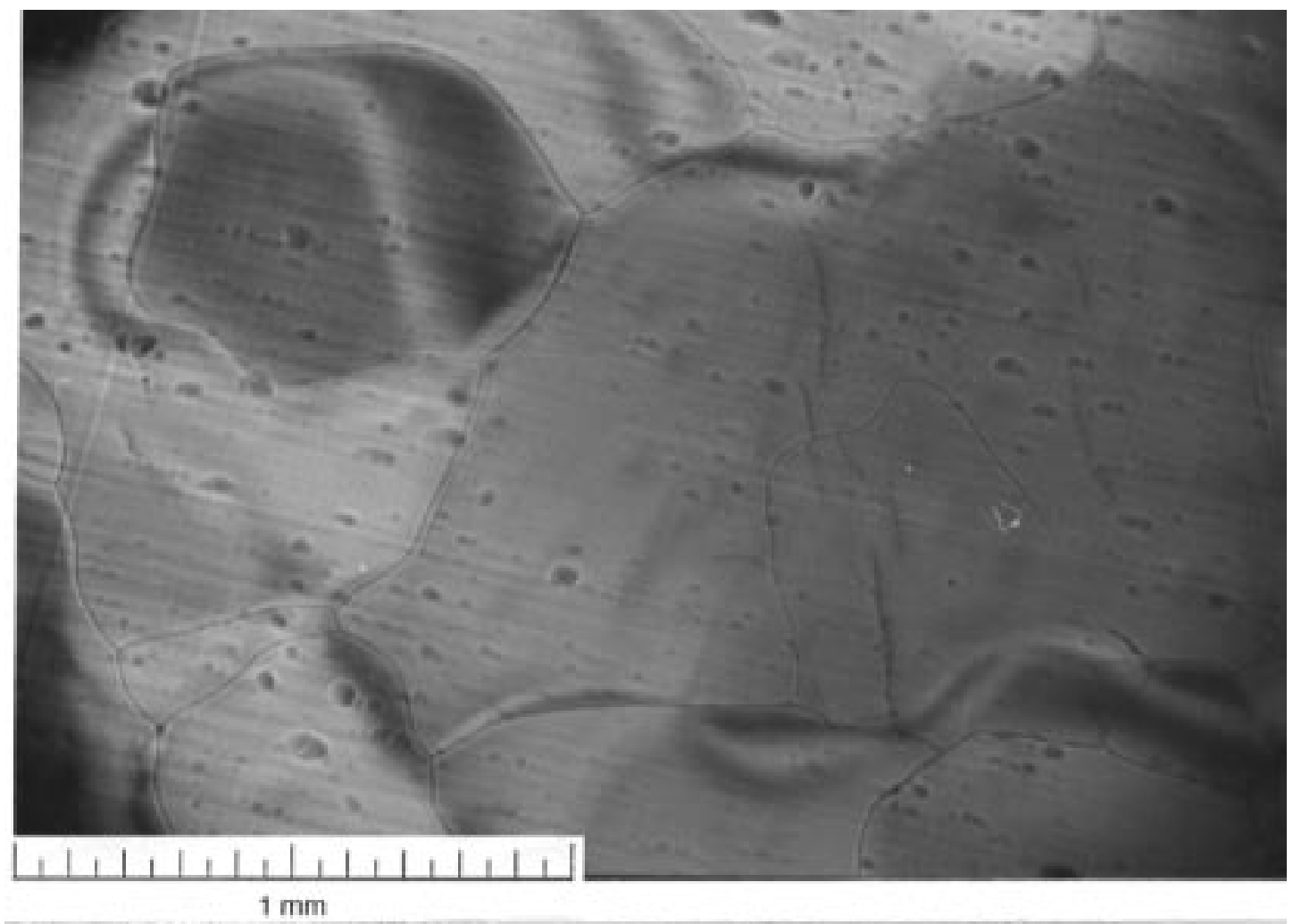

Figure D19. Pond ice at a depth of $15 \mathrm{~cm}$ (horizontal section).

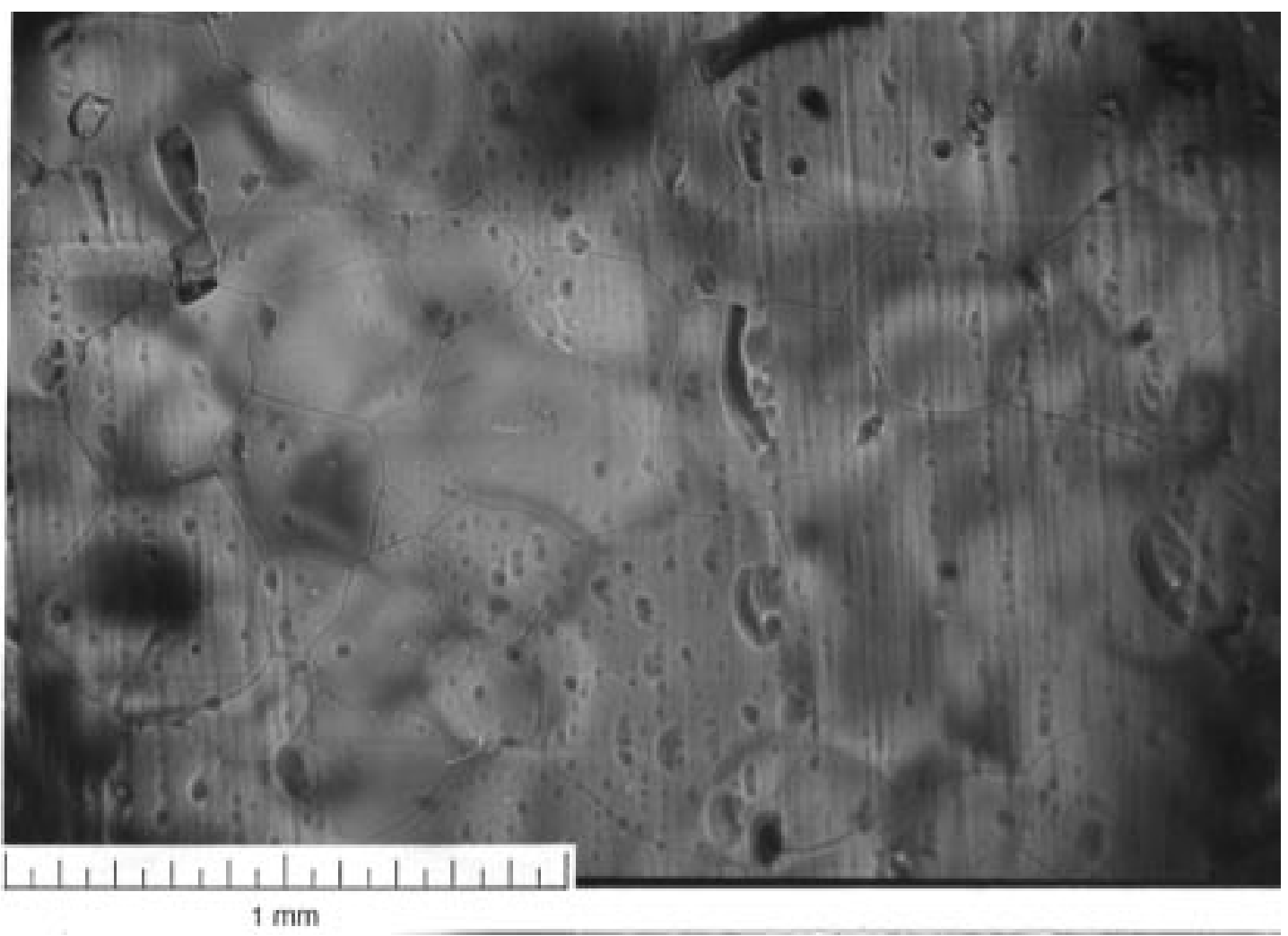

Figure D20. Pond ice at a depth of $15 \mathrm{~cm}$ (vertical section). 


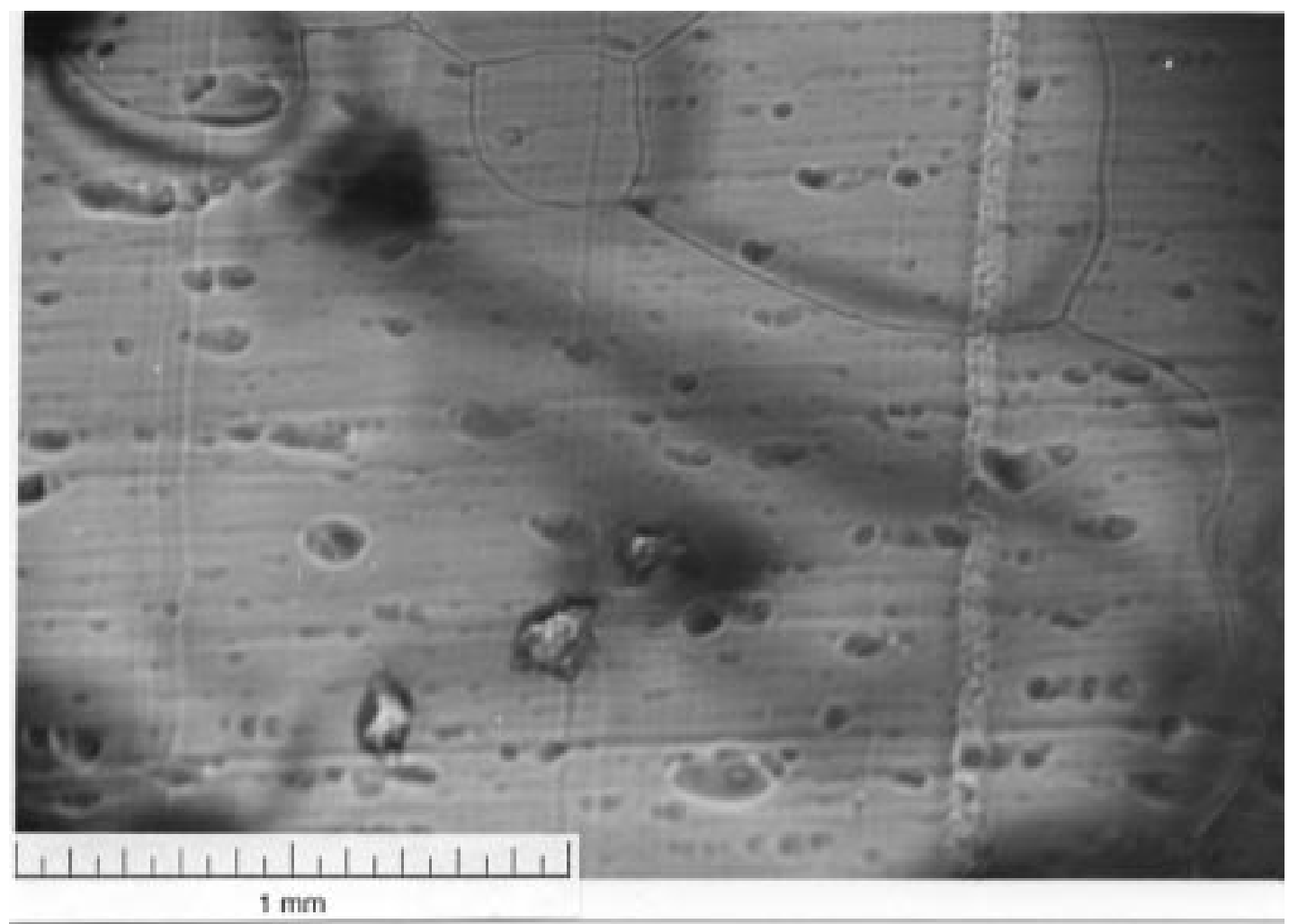

Figure D21. Pond ice at a depth of $50 \mathrm{~cm}$ (horizontal section).

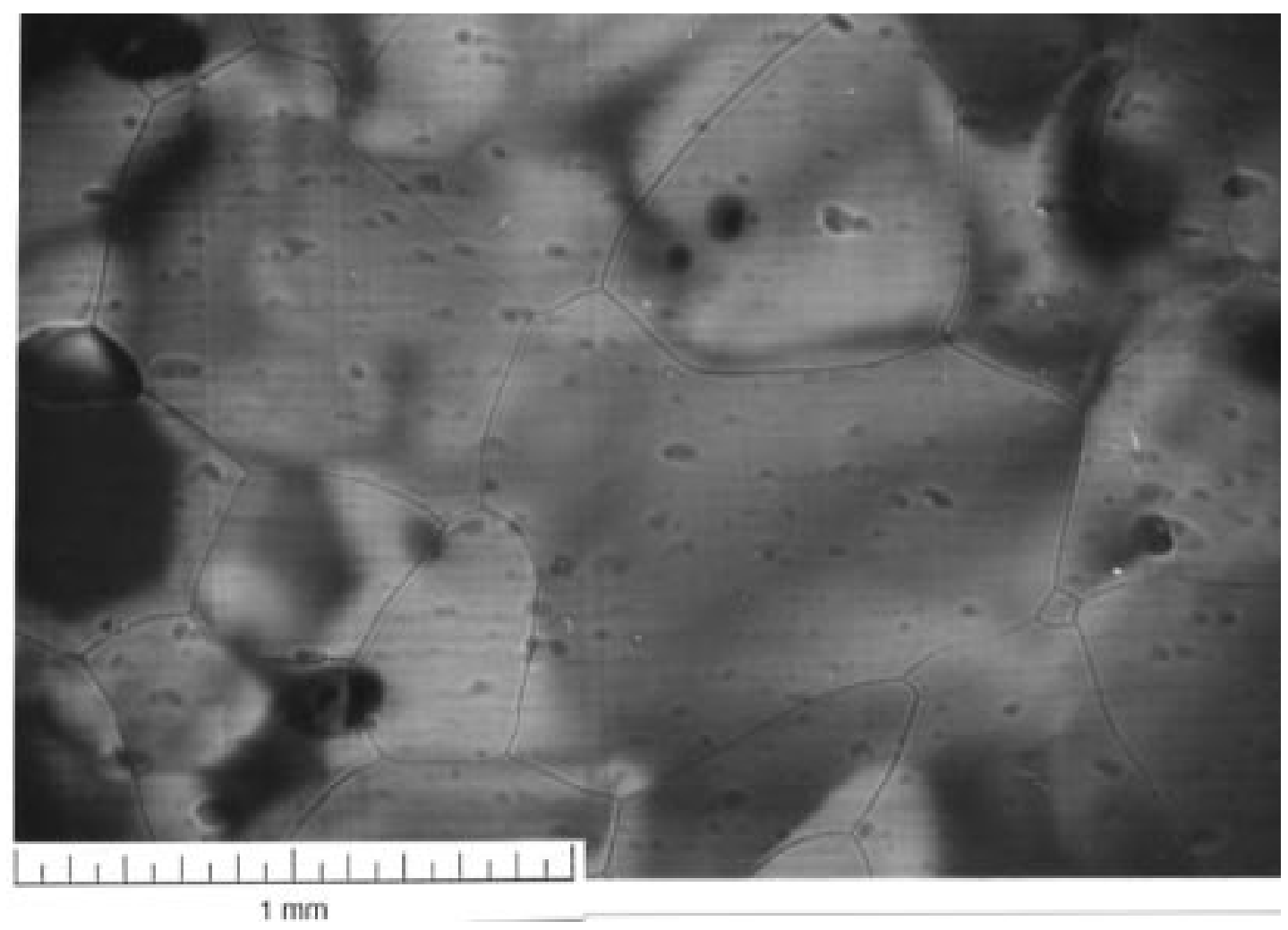

Figure D22. Pond ice at a depth of $50 \mathrm{~cm}$ (vertical section). 


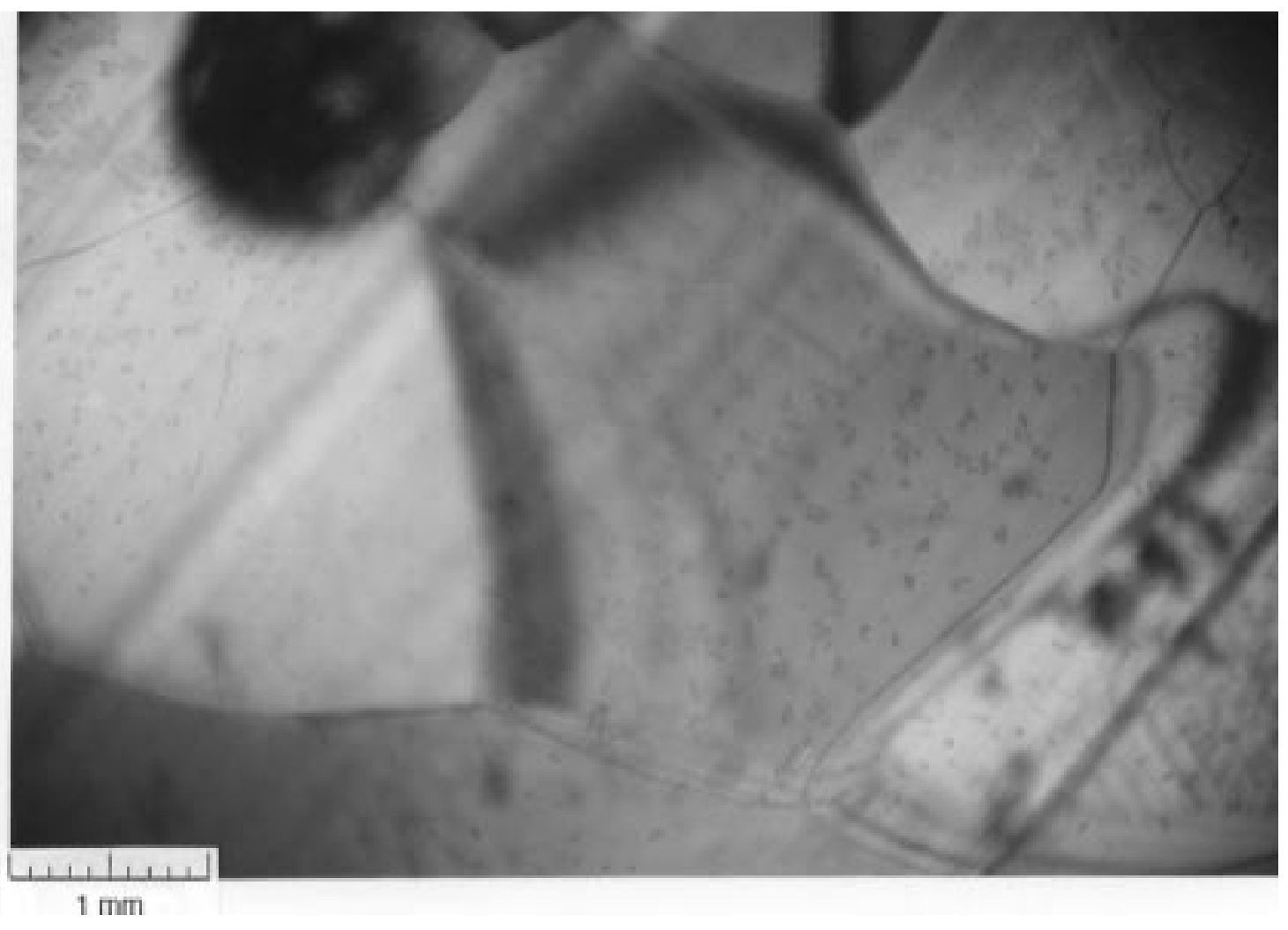

Figure D23. Clear lake ice (horizontal section).

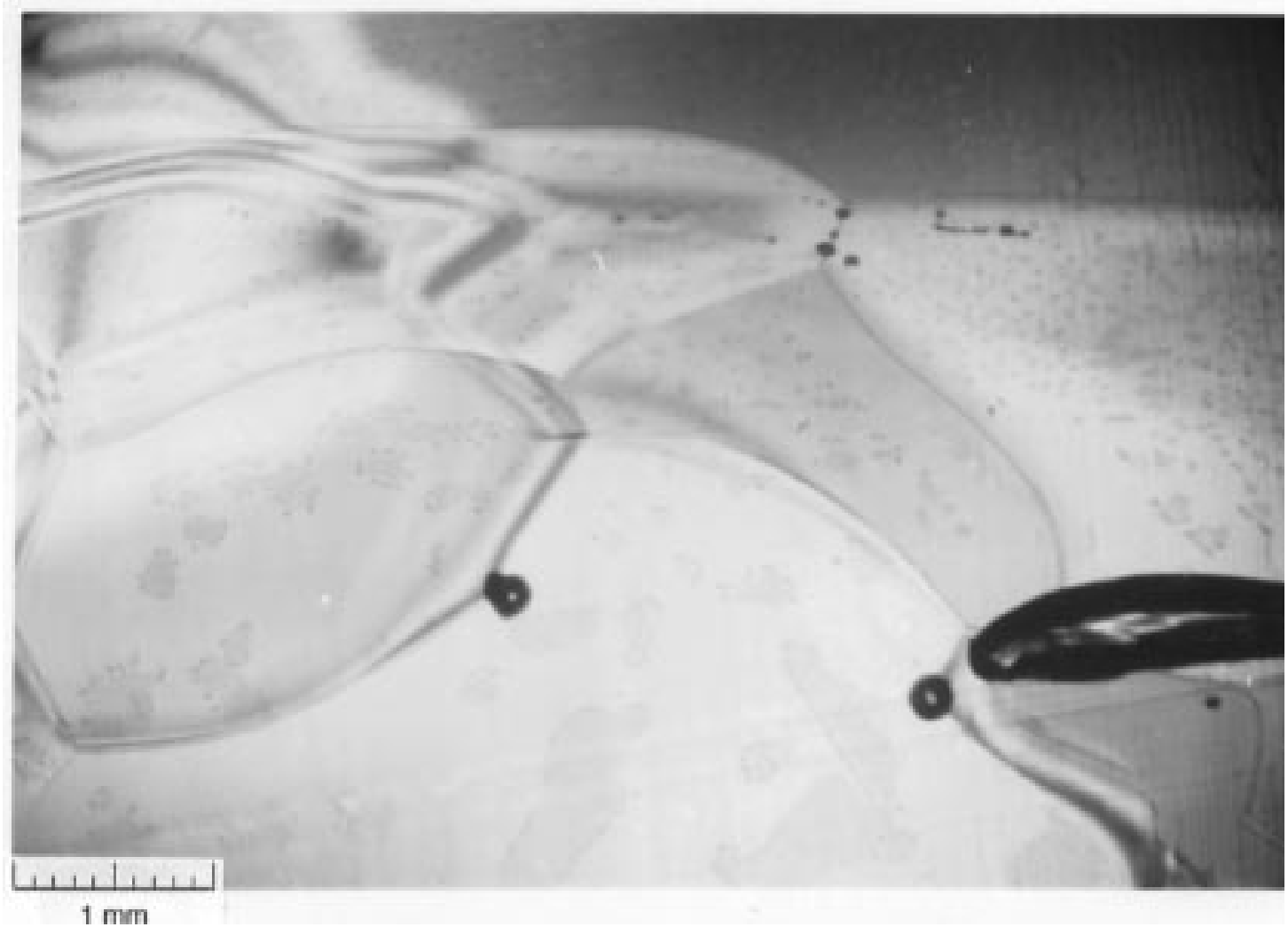

Figure D24. Clear lake ice (vertical section). 


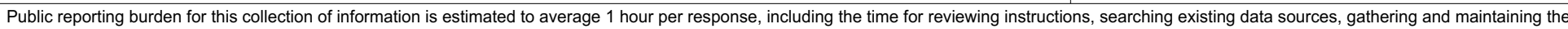

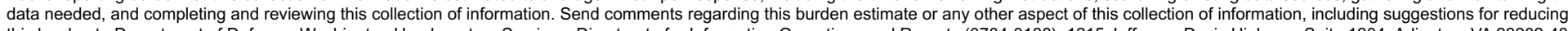

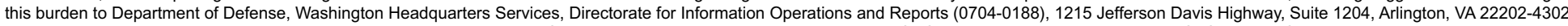

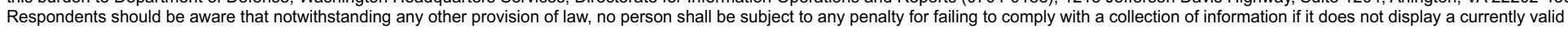
OMB control number. PLEASE DO NOT RETURN YOUR FORM TO THE ABOVE ADDRESS.
\begin{tabular}{l|l} 
1. REPORT DATE $(D D-M M-Y Y)$ & 2. REPORT TYPE
\end{tabular}
August 2001
2. REPORT TYPE
Technical Report
3. DATES COVERED (From - To)

4. TITLE AND SUBTITLE

5a. CONTRACT NUMBER

A Method for Producing Fine-Grained Ice from Snow Compaction

5b. GRANT NUMBER

5c. PROGRAM ELEMENT NUMBER

\section{AUTHOR(S)}

5d. PROJECT NUMBER

Deborah Diemand and Valery Klokov

5e. TASK NUMBER

5f. WORK UNIT NUMBER

7. PERFORMING ORGANIZATION NAME(S) AND ADDRESS(ES)

8. PERFORMING ORGANIZATION REPORT NUMBER

U.S. Army Engineer Research and Development Center

Cold Regions Research and Engineering Laboratory

72 Lyme Road

ERDC/CRREL TR-01-12

Hanover, New Hampshire 03755-1290

9. SPONSORING/MONITORING AGENCY NAME(S) AND ADDRESS(ES)

10. SPONSOR / MONITOR'S ACRONYM(S)

Office of the Chief of Engineers

Washington, DC 20314

11. SPONSOR / MONITOR'S REPORT NUMBER(S)

\section{DISTRIBUTION / AVAILABILITY STATEMENT}

Approved for public release; distribution is unlimited.

Available from NTIS, Springfield, Virginia 22161.

\section{SUPPLEMENTARY NOTES}

\section{ABSTRACT}

This report describes a preliminary study of the fabrication of building blocks by converting snow directly to ice without the very high energy cost of melting it first. This was accomplished by a hot sinter technique that produced a very fine-grained material that is considerably stronger than natural ice. The very high pressures applied to the snow appear not only to have reduced the grain size present in the raw material (natural snow), but to have completed the sintering process before the block was removed from its form, as there was no convincing increase in strength at any storage temperature over a period of 20 days, nor were there any striking crystallographic changes.

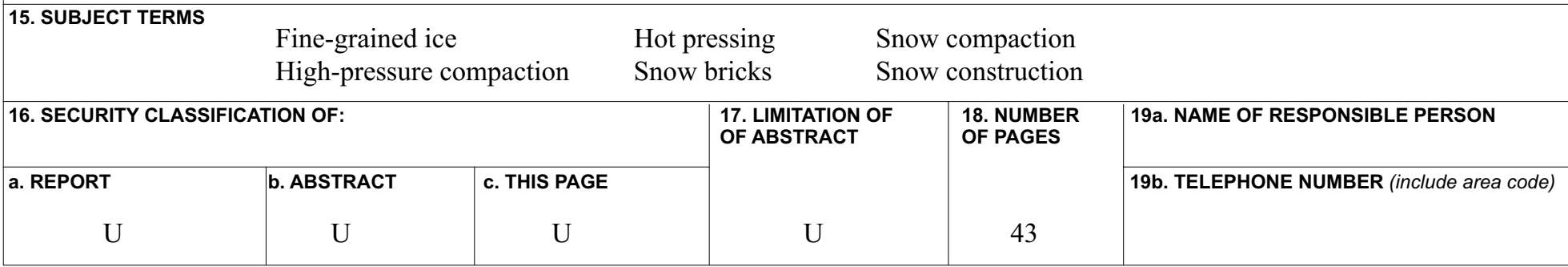

